Florida International University

FIU Digital Commons

$11-9-2018$

\title{
Fall Safety Perspective of the Construction Professionals in Miami-Dade and Broward Area
}

Saurav Pokharel

spokh006@fiu.edu

Follow this and additional works at: https://digitalcommons.fiu.edu/etd

Part of the Construction Engineering and Management Commons

\section{Recommended Citation}

Pokharel, Saurav, "Fall Safety Perspective of the Construction Professionals in Miami-Dade and Broward Area" (2018). FIU Electronic Theses and Dissertations. 3954.

https://digitalcommons.fiu.edu/etd/3954

This work is brought to you for free and open access by the University Graduate School at FIU Digital Commons. It has been accepted for inclusion in FIU Electronic Theses and Dissertations by an authorized administrator of FIU Digital Commons. For more information, please contact dcc@fiu.edu. 


\title{
FLORIDA INTERNATIONAL UNIVERSITY
}

Miami, Florida

\section{FALL SAFETY PERSPECTIVE OF THE CONSTRUCTION PROFESSIONALS IN MIAMI-DADE AND BROWARD AREA}

\author{
A thesis submitted in partial fulfillment of \\ the requirements for the degree of \\ MASTER OF SCIENCE \\ in \\ CONSTRUCTION MANAGEMENT
}

by

Saurav Pokharel 
To: Dean John L. Volakis

College of Engineering and Computing

This thesis, written by Saurav Pokharel, and entitled Fall Safety Perspective of the Construction Professionals in Miami-Dade and Broward Area, having been approved in respect to style and intellectual content, is referred to you for judgment.

We have read this thesis and recommend that it be approved.

Lu Zhang

Jose A. Faria

Nipesh Pradhananaga, Major Professor

Date of Defense: November 9, 2018

The thesis of Saurav Pokharel is approved.

Dean John L. Volakis

College of Engineering and Computing

Andrés G. Gil

Vice President for Research and Economic Development and Dean of the University Graduate School

Florida International University, 2019 
(C) Copyright 2019 by Saurav Pokharel

All rights reserved. 


\section{DEDICATION}

To My Parents. 


\section{ACKNOWLEDGMENTS}

I would like to express my sincerest gratitude to my advisor Dr. Nipesh Pradhananga for his continuous support and guidance during my graduate study. This thesis would not have been possible without his supervision and direction.

I would also like to thank the members of my dissertation committee, Dr. Jose Faria and Dr. Lu Zhang for their support during my research and for finding time in their busy schedule for my dissertation.

I would also like to thank Juan Quesada, Eddy Etienne, and Edgar Polo for helping me to collect data from the participants of the fall training program.

I would like to thank all my friends and colleagues for their support throughout my rigorous journey of the graduate studies.

Lastly, I also wish to acknowledge OSHA’s Susan Harwood Training Grant Program (under Grant SH-31201-SH7) for their funding support of the fall training program and their assistance in data collection. 


\title{
ABSTRACT OF THE THESIS \\ FALL SAFETY PERSPECTIVE OF THE CONSTRUCTION PROFESSIONALS IN MIAMI-DADE AND BROWARD AREA
}

\author{
by
}

Saurav Pokharel

Florida International University, 2019

Miami, Florida

\section{Professor Nipesh Pradhananga, Major Professor}

The main purpose of this study was to understand the fall safety perspective of the construction professionals by analyzing their attributes, workplace safety knowledge, behavior and conduct, and identifying trends in their fall safety opinions. The study involved analysis of the survey data of the 847 construction professionals who participated in the fall training program conducted in the Miami-Dade and Broward County area. About two-thirds of the participants felt that they had adequate safety knowledge, and about half of them said they encountered fall hazards on a daily or weekly basis. The study also found that vulnerability of fall hazards decreased as the age of the participants increased. Lesser susceptibility to fall hazards was observed for the participants who were provided safety training on site, and those who have stricter employers. This study also addresses the knowledge gap in the study of construction workers' fall safety opinions by analyzing the most recent data set. 


\section{TABLE OF CONTENTS}

CHAPTER

PAGE

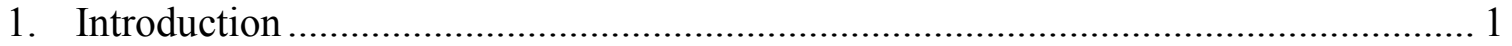

1.1. Problem Statement........................................................................... 1

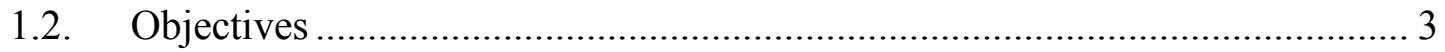

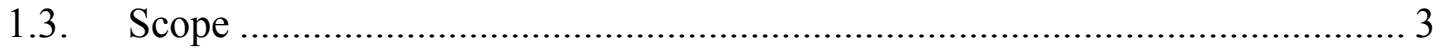

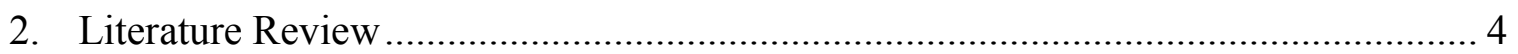

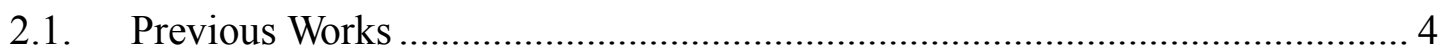

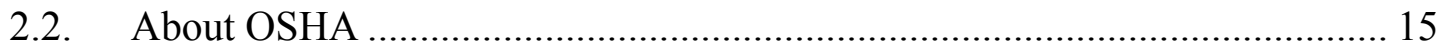

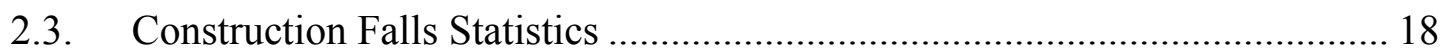

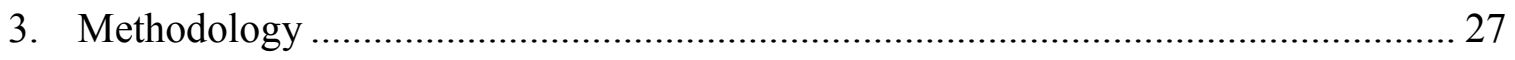

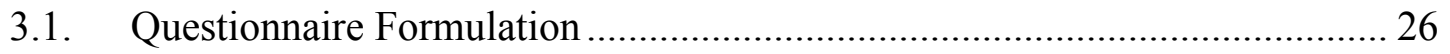

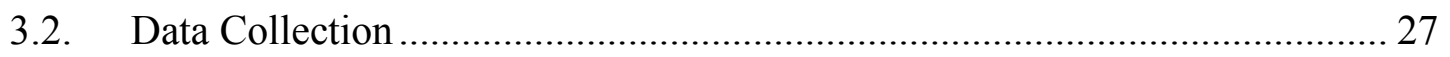

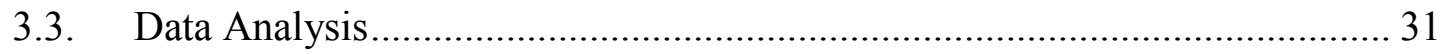

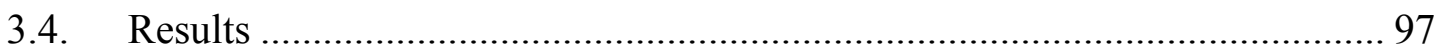

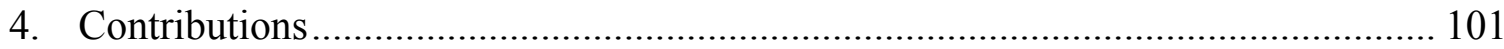

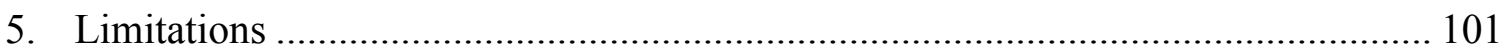

6. Future Works/Recommendations ……………………........................................ 102

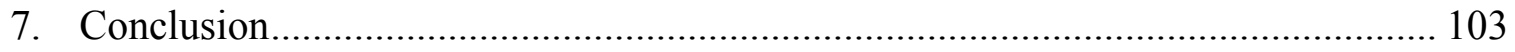

List of References............................................................. 105

APPENDIX 


\section{LIST OF TABLES}

TABLE

PAGE

Table 1: Falls by location, Hu et al. (2003) …………………….............................. 5

Table 2: Casual factors influencing the fall incidents in the construction industry, $\mathrm{Hu}$ et al. (2011)

Table 3: Factors associated with falls from height, Nadhim et al. (2016) ......................... 7

Table 4: List of Fall Training Sessions Conducted .......................................................... 31

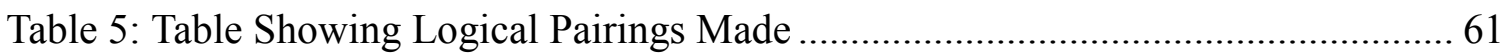

Table 6: Observed Frequency Table for Q2 vs Q13 ………………………………….... 62

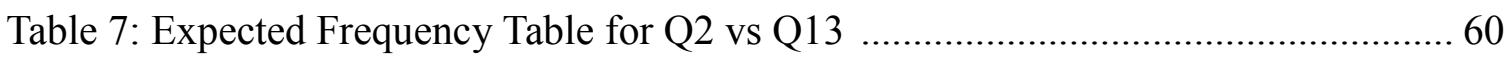

Table 8: Yates' Correction Calculation Table for Q2 vs Q13 ……………………......... 60

Table 9: Observed Frequency Table for Q3 vs Q21 …………………………………....... 63

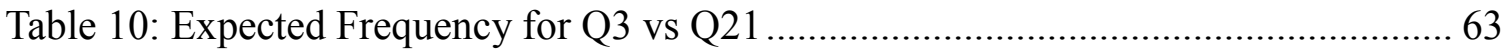

Table 11: Yates Correction Calculation Table for Q3 vs Q21 …………………………... 64

Table 12: Observed Frequency Table for Q3 vs Q8 ………………………………....... 67

Table 13: Expected Frequency Table for Q3 vs Q8 ……………………………….... 68

Table 14: Yates Correction Calculation Table for Q3 vs Q21 .......................................... 68

Table 15: Observed Frequency Table for Q4 vs Q13 ……………………………….... 71

Table 16: Expected Frequency for Q4 vs Q13 .............................................................. 71

Table 17: Yates Correction Calculation Table for Q4 vs Q13 ………………………..... 72

Table 18: Observed Frequency Table for Q19 vs Q8 ………………………………..... 74

Table 19: Expected Frequency Table for Q19 vs Q8 ………………………………... 75

Table 20: Yates Correction Calculation Table for Q19 vs Q8 ......................................... 75

Table 21: Observed Frequency Table for Q21 vs Q6 .................................................... 78 
Table 22: Expected Frequency Table for Q3 vs Q6 .................................................. 78

Table 23: Yates Correction Calculation Table for Q21 vs Q6...................................... 79

Table 24: Observed Frequency Table for Q20 vs Q9 ................................................ 82

Table 25: Expected Frequency Table for Q20 vs Q9 ............................................... 82

Table 26: Yates Correction Calculation Table for Q20 vs Q9..................................... 83

Table 27: Observed Frequency Table for Q13 vs Q6 ................................................ 86

Table 28: Expected Frequency Table for Q13 vs Q6 .............................................. 86

Table 29: Yates Correction Calculation Table for Q13 vs Q6...................................... 87

Table 30: Observed Frequency Table for Q19 vs Q9 ............................................. 90

Table 31: Expected Frequency Table for Q19 vs Q9 ................................................. 90

Table 32: Yates Correction Calculation Table for Q19 vs Q9.................................... 91

Table 33: Observed Frequency Table for q20 vs Q6 ................................................. 94

Table 34: Expected Frequency Table for Q20 vs Q6 ............................................... 94

Table 35: Yates Correction Calculation Table for Q20 vs Q6.................................... 95 
FIGURE

\section{LIST OF FIGURES}

PAGE

Figure 1: Number of fatal work injuries in the US, 2016 ........................................... 19

Figure 2: Fatal work-related falls to a lower level by industry, 2011-16..................... 20

Figure 3: Fatal work-related falls to a lower level by source and height of fall, 2011-1621

Figure 4: Percent of fatal falls to lower level by height of fall, 2016 ............................ 19

Figure 5: Falls vs Other Fatalities in Construction, 2011-2015 .................................. 20

Figure 6: Work-related fatalities from falls to a lower level in US construction, 2011-

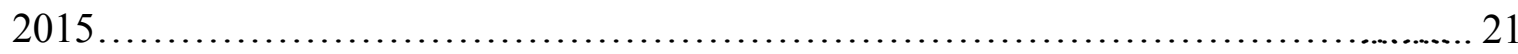

Figure 7: Fatal Injuries in Private Industry in Florida, 2015-16 .................................. 22

Figure 8: Fatal injuries in Construction and extraction occupations in Florida, 2015-16 23

Figure 9: Fatal occupational injuries by event or exposure, US and Florida - 2016 ....... 24

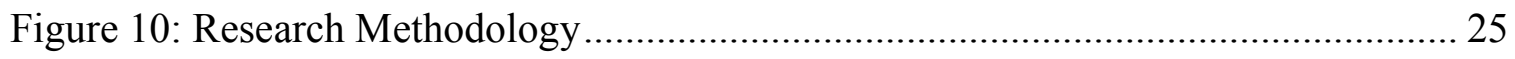

Figure 11: Role in the construction site in Percentage ............................................... 33

Figure 12: Years of Experience by Percentage ........................................................ 34

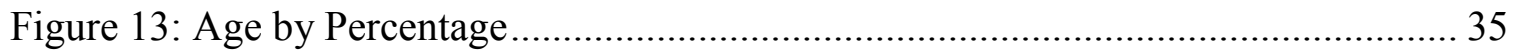

Figure 14: Level of education by Percentage ......................................................... 36

Figure 15: Requisite of a safety training certificate to get a job in Percentage ................ 37

Figure 16: Provision of safety training on site by Employer in Percentage .................... 38

Figure 17: Type of safety training provided in Percentage ........................................ 39

Figure 18: Adequacy of Safety equipment provided by the employers in Percentage ..... 40

Figure 19: Employers' strictness about safety measures in Percentage ........................ 41

Figure 20: Percentage of participants who get noticed by employers if they don't follow safety procedures. 
Figure 21: Percentage of participants who get rewarded by employers for following safety procedures

Figure 22: Percentage of participants who would be encouraged to follow

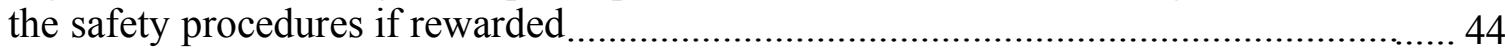

Figure 23: Participants who feel they have adequate safety knowledge in Percentage .... 45

Figure 24: Participants' frequency of encounter with fall hazards in Percentage ........... 46

Figure 25: Considered safe lower level in Percentage ................................................ 47

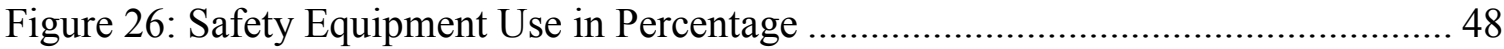

Figure 27: Reasons for not wearing safety equipment in Percentage ............................ 49

Figure 28: Should have a choice of not following safety measures in Percentage........... 50

Figure 29: Coworkers follow safety measures in Percentage ........................................ 51

Figure 30: Have witnessed a co-worker having an accident due to fall hazards in

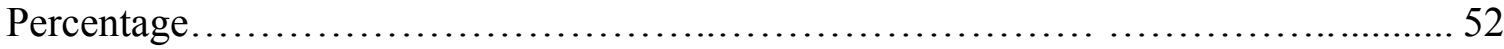

Figure 31: Effect of Co-workers' safety behavior in Percentage ................................... 53

Figure 32: Action taken if you see coworkers not following the safety proceducres in Percentage............................................................................... 54

Figure 33: Experience of participants vs Adequacy of Knowledge about hazards and saafety measures

Figure 34: Age of the participants vs Effect of coworkers' safety behavior .................... 65

Figure 35: Age of the participant vs Adequacy of the safety equipment provided by

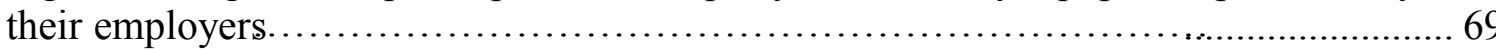

Figure 36: Level of education vs adequacy of knowledge about hazards and prevention measures 
Figure 37: Provision of safety training on site by employer vs Co-workers' safety habit 76

Figure 38: Provision of safety training on site by the employer vs Effect of co-

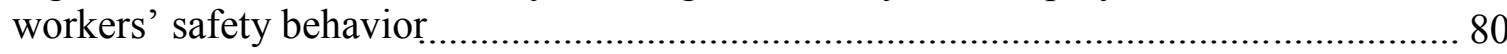

Figure 39: Strictness of the employer vs Witnessing co-worker accident........................ 84

Figure 40: Provision of safety training on site from employers Vs Adequacy of knowledge about hazard and prevention measures ......................................................... 88

Figure 41: Strictness of the employer VS Co-workers' safety habit .............................. 92

Figure 42: Provision of training from the employer VS Witnessing a co-worker's

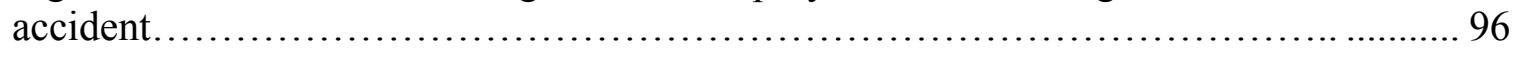




\section{Introduction}

\subsection{Problem Statement}

The construction industry is prone to workplace injuries and fatalities. According to the US Bureau of Labor Statistics [1], 5190 fatal work injuries occurred in the US in 2016 which was a 7\% increase from 2015. Private industry employers also reported about 2.9 million non-fatal workplace injuries and illness. Among those, 991 fatal and 203.5 thousand non-fatal workplace injuries and illness happened in the private construction sector. According to Occupational Safety and Health Administration (OSHA), falls, struck by object, electrocution, and caught-in/between were the top four causes of fatalities in private construction sector: $63.7 \%$ deaths in 2016 [2]. Fall was the number one cause attributed for 384 out of those 991 deaths in the construction sector. A considerable number of occupational fall fatalities occur in Florida too [3]. In Florida, 309 fatal work injuries occurred in 2016. Seventy-six deaths occurred in the Florida construction industry 2016 which was ten more than 2015, and the highest among the industry sector. Falls, slips, or trips caused 64 deaths in Florida which is $21 \%$ of total fatal occupational injuries in 2016, higher than the national average of $16 \%$ of fatal occupational injuries due to falls, slips, or trips.

The data above illustrate the state of the construction industry in terms of fall safety in the workplace and the need for the study of fall hazards and prevention measures. The construction industry in the US usually follows the top-down [4] approach in terms of workplace safety. Plans, policies, and regulations are made at a higher level by the government or management and enforced on construction workers through regulating 
agencies such as OSHA, or through safety supervisors and managers at the job site. Despite the endeavors regarding fall safety such as studies of the causes of falls [5], [6], implementation of stricter regulations and policies, conduction of fall safety training [7], [8], and employment of manpower to prevent falls, the statistics show that a huge number of workplace fatalities and especially fall fatalities occur each year.

A study of the existing body of knowledge on fall safety showed inadequate effort in understanding the construction workers' opinions on fall safety. While there are many parties such as employers, employees, safety managers, government agencies like OSHA, etc. who have different responsibilities to ensure workplace safety, workplace injuries and fatalities ultimately occur due to the workers' decision to undertake risky activities. After all, workplace accidents happen when workers are unable to identify unsafe conditions or take risks despite identifying the unsafe conditions [5]. Very few researches have been done on construction workers' perspectives [9], [10], [11], [12]. However, they are not specifically concentrated on fall hazards, and more focused on differentiating opinions of English-speaking versus non-English speaking, documented versus undocumented, unionized versus non-unionized workers and so on. Thus, a need for research which takes the bottom-up approach towards understanding fall safety scenario in the construction industry through the analysis of construction professionals' opinions, was recognized. Incidentally, a fall protection training, targeting construction workers in the Miami-Dade and Broward County area, was conducted under the OSHA's Susan Harwood Grant Program. The need for safety training of construction workers in Florida and the whole of the US, with more emphasis on fall protection training, is obvious. Our research was designed with the aim to address the existing gap in the study of the workers' perspective 
by analyzing the data collected from workers who come to the fall safety training. This research attempts to understand the fall safety scenario from the perspective of the construction professionals in the Miami-Dade and Broward County area. This research also aims to obtain valuable information concerning fall behavior, knowledge, and conduct of the construction professionals in the Miami-Dade and Broward County area.

\subsection{Objectives}

The main objective of this research is to understand the fall safety perspective of the construction professionals in Miami-Dade and Broward County area and to associate the demographic information, knowledge, and experience of construction professionals to fall exposure. This research also aims to identify the groups safer from and the groups susceptible to the fall hazards and develop a basis for group focused fall training program.

\subsection{Scope}

This research is concentrated on the analysis of the fall safety conduct and understanding of construction professionals in the Miami-Dade and Broward County area. The findings of this research are based on the data obtained from the construction professionals who came to receive the fall prevention training. Data collected from construction professionals is limited to their responses to the questions about fall safety on a survey questionnaire, described in a later section. 


\section{Literature Review}

\subsection{Previous Works}

\subsubsection{Causes of Falls}

Various researches have been conducted to understand the causes of falls on a job site. Dong et al. (2017) [6] studied 768 fatalities in the construction industry from 1982 to 2015 on National Institute for Occupational Safety and Health (NIOSH) database and found that $81 \%$ of the people who fell did not use Personal fall arrest systems (PFAS). While $54 \%$ of the people who fell did not have access to PFAS, $25 \%$ of the fall decedents did not use the PFAS when they fell despite having access to them. Higher lack of access to PFAS, about $70 \%$, was found for workers in the residential building, roofing, siding, and sheet metal industry. They also found that fall decedent of smaller establishments (20 or fewer employees) were less likely to have PFAS than those of larger establishments (200 or more employees).

A study of 621 case reports by Chi et al.(2005) [7] found that lack of complying scaffolds, bodily action, unguarded openings, inappropriate protections, or the removal of protections improper use of Personal Protection Equipment (PPE), being pulled down heavy object, overexertion and unusual control and the use of unsafe ladders and tools, and poor work practices were the causes of fatal falls.

Huang et al. (2003) [8] studied construction fall accidents data accumulated by OSHA from 1990 to 2001, emphasizing on the last five years of that period when more data was accumulated. They found that most falls occur from the roof, followed by falls from scaffold and ladders (Table 1). 
Table 1: Falls by location, Hu et al. (2003)

\begin{tabular}{|c|c|c|}
\hline Location of Falls & Count & Percent \\
\hline Falls from the roof & 333 & $28.36 \%$ \\
\hline Fall from/with structure (other than roof) & 227 & $19.34 \%$ \\
\hline Falls from/ with ladder & 133 & $11.33 \%$ \\
\hline Falls from/ with scaffold staging & 153 & $13.03 \%$ \\
\hline Falls through opening & 90 & $7.67 \%$ \\
\hline Falls from/ with bucket (aerial lift/ basket) & 37 & $3.15 \%$ \\
\hline Falls from/ with platform catwalk & 28 & $2.39 \%$ \\
\hline Fall from vehicle (vehicle/construction equipment) & 27 & $2.30 \%$ \\
\hline Fall (others) & 102 & $8.69 \%$ \\
\hline Collapse of Structure & 13 & $1.11 \%$ \\
\hline Other & 31 & $2.64 \%$ \\
\hline Total & 1174 & $100 \%$ \\
\hline
\end{tabular}

Hu et al. (2011) [9] overviewed 531 articles on causes of falls in the construction industry. They coded 121 relevant articles to conduct a structured meta-analysis to find casual factors influencing the fall incidents in the construction industry. They found that three micro-variables were most associated with the risk of fall and injuries ( 
Table 2). Working surfaces and platforms (e.g. slippery surfaces, improper concrete surfaces), workers' safe behaviors and attitudes (e.g. safety procedure, perceived risk, horseplay while working) and construction structure and facilities (e.g. the stability of the building's framework, and the reliability of the construction equipment) were the three most commonly mentioned causes of fall in those reviewed articles. 
Table 2 below lists the casual factors influencing the fall incidents in the construction industry. 
Table 2: Casual factors influencing the fall incidents in the construction industry, Hu et al. (2011)

\begin{tabular}{|c|l|c|c|}
\hline Ranking & \multicolumn{1}{|c|}{ Macro-Variables of factors } & $\begin{array}{c}\text { Consistency } \\
\text { of agreement }\end{array}$ & $\begin{array}{c}\text { Number of } \\
\text { link } \\
\text { occurrences }\end{array}$ \\
\hline 1 & Working surfaces and platforms & Strong & 128 \\
\hline 2 & Workers' safe behaviors and attitudes & Strong & 127 \\
\hline 3 & Construction structure and facilities & Strong & 96 \\
\hline 4 & Contractors/managerial level safety intervention & Strong & 55 \\
\hline 5 & Workers' age & Minor & 53 \\
\hline 6 & PPE and methods & Strong & 51 \\
\hline 7 & Workers' experience & Major & 51 \\
\hline 8 & Workers' health and physical characteristics & Strong & 50 \\
\hline 9 & Occupation & Major & 45 \\
\hline 10 & Construction environment & Strong & 40 \\
\hline 11 & Weather & Strong & 32 \\
\hline 12 & Workers' training and education & Major & 24 \\
\hline 13 & Size of construction company & Major & 20 \\
\hline 14 & Workers' morale & Strong & 16 \\
\hline 15 & Working time/day & Minor & 10 \\
\hline 16 & Construction industry standard & Strong & 9 \\
\hline 17 & Terrain and location of construction site & Minor & 7 \\
\hline 18 & Height of workplace & Strong & 6 \\
\hline 19 & Construction material & Strong & 5 \\
\hline 20 & Economic status & Strong & 4 \\
\hline & & & \\
\hline
\end{tabular}

Nadhim et al. (2016) [10] conducted a scientific review of 297 articles related to fall incidents. They conducted a synthesis of macro-variables approach on 75 relevant articles to come up with leading causes of fall from height. They found that five common factors are stated to be associated with fall from heights in those articles ( 
Table 3). Risky activities, individual characteristics, site conditions, organizational characteristics, agents, and weather conditions were the most mentioned factors influencing fall from heights. 
Table 3: Factors associated with falls from height, Nadhim et al. (2016)

\begin{tabular}{|c|c|c|c|}
\hline No. & Factors & Variables & No. of Papers \\
\hline 1 & Risky Activities & $\begin{array}{l}\text { Working at Height: with } \\
\text { complexity, hardship, prolong } \\
\text { tasks } \\
\end{array}$ & 39 \\
\hline 2 & Individual Characteristics & $\begin{array}{c}\text { Demography: age, gender, weight, } \\
\text { ethnicity etc.; Knowledge Level: } \\
\text { lack of education, experience, } \\
\text { training, etc.; Human behaviors: } \\
\text { misjudgment, attitude, unsafe } \\
\text { behavior \& carelessness, etc.; } \\
\text { Workers health/characteristics: } \\
\text { fatigue, sleep deprivation or } \\
\text { depression }\end{array}$ & 31 \\
\hline 3 & Site Conditions & $\begin{array}{c}\text { Insufficient lighting \& } \\
\text { illumination; } \\
\text { Unprotected/defective platform \& } \\
\text { surface } \\
\end{array}$ & 13 \\
\hline 4 & Organization/Management & $\begin{array}{l}\text { Small-medium sized companies: } \\
\text { lack training programs; } \\
\text { Contractors \& sub-contractors: } \\
\text { lack of proper/safe equipment; } \\
\text { Shift work: night shifts and break } \\
\text { periods; Project Timeline: } \\
\text { pressure to accelerate. }\end{array}$ & 11 \\
\hline 5 & Agent & $\begin{array}{c}\text { Improper position or defective: } \\
\text { ladder/scaffold } \\
\text { (erecting/dismantling) }\end{array}$ & 5 \\
\hline 6 & Weather/Environmental Conditions & $\begin{array}{l}\text { Frost, snow, heavy rain, humidity, } \\
\text { extreme temperatures, noise, dust, } \\
\text { etc. }\end{array}$ & 4 \\
\hline
\end{tabular}

\subsubsection{Falls and workers' characteristics}

Researchers have also tried to observe the association of falls with workers' age, ethnicity, trades, and so on. A study of fatal falls from the roof in the US construction industry between 1992 to 2009 by Dong et al. (2013) [11] found that a third of fatal falls were roof fatalities. Roofers, ironworkers, and workers in residential construction were facing higher fall fatalities risks. Roof fatalities rate was higher among younger $(<20$ years) 
and older (>44 years) workers, Hispanics, and immigrant workers. Small construction establishments (1-10 employees) accounted for $67 \%$ of roof fatalities.

Sa et al. (2009) [12] compared the fall risks for residential and commercial workers in Midwest USA. They conducted a cross-sectional sample analysis of surveys from 252 workers. They found that residential workers were more likely to fall than commercial workers. Olbina et al. (2011) [13] studied the safety practices of roofing contractors of Florida who employed Hispanic workers through a survey based on prior studies facilitated by Florida Roofing, Sheet Metal and Air Conditioning Contractors (FRSA). They found that large roofing contractors (more than 40 employees) implemented more safety programs and reported better safety performances than smaller roofing contractors (40 or fewer employees). They also found that injury rates significantly decreased in Hispanic workers when they were offered training in Spanish.

Another study of fatality data from Census of Fatal Occupational Injuries from 1992 through 2008 by Dong et al. (2012) [14] found that older workers (>55 years) are 50\% more likely to die from fall than any other injuries compared to younger workers (16-54 years). Falls from ladders lead to the highest death rate for older workers. Old roofers face nearly three times the fatal fall risk than younger roofers. Roofers, ironworkers, and power line installers, both young and old, were faced a higher fall risk than workers from other categories such as laborer, carpenter, mason and so on. Fatal fall rates were higher for selfemployed workers or small establishment employees than workers employed in large establishments. 


\subsubsection{Costs of Fall Incidents}

There are huge financial implications of workplace injuries to a business organization. An estimate from National Academy of Social Insurance (NASI) (2017) [15] states that $\$ 61.9$ billion in worker benefits was paid by workers' compensation programs to about 135.6 million workers across all industries in 2015. According to the Center for Construction Research and Training (CPWR) [16], 3.6\% of employer compensation costs were spent on workers' compensation in the construction industry in 2015, which is $71 \%$ higher than the percentage for the overall goods-producing industries combined, and more than twice the average costs for employers in all industries.

According to OSHA [17], Occupational injuries and illness cost US businesses about $\$ 170$ billion per year. It is estimated that establishing safety and health systems in workplaces can reduce those costs up to forty percent.

OSHA conducted a study of workers' compensation data (2012) [18] from insured employers of 36 states who report to the National Council on Compensation Insurance, Inc. (NCCI) of three years period from 2005 to 2007. It found that fall from an elevation of roofers and carpenters cost $\$ 106,000$ and $\$ 96,000$ respectively. At the same time, the average cost of a fall from elevation for all other occupational classifications was under $\$ 50,000$. NCCI covered approximately $1 / 3$ of total workers' compensation benefits paid out annually in the US at the time.

Lipscomb et al. (2014) [19] studied Workers' Compensation (WC) costs related to fall from a height to union carpenters in Washington state. They found that WC costs had 
reduced over the 20 years (1989-2008), but costs related to falls was still significantly costly, with mean payment per fall up to $\$ 40,000$ towards the end of that period.

\subsubsection{Fall Training Programs}

Researchers have found that fall training programs are effective. Kaskutas et al. (2013) [20] studied a fall prevention program for foremen in the residential construction industry. They found that compliance with fall protection increased in workers and their unsafe behaviors decreased after the program was conducted. The training also enhanced the foremen's on-job training and safety communication with other workers in the job sites.

Evanoff et al. (2016) [21] studied a fall prevention program in St. Louis which included surveys from 1018 apprentice carpenters and observational audits from 197 sites. They observed that the revised fall training of carpenters in residential construction leads to improvement in fall safety knowledge, self-reported worksite behaviors, risk perceptions, and safety climate.

Williams et al. (2010) [22] conducted a study of peer-lead participatory health and safety training program of 300 Latino construction day laborers in New Jersey. They found that the training led to the increase in the use of some PPEs, increase in self-safety practices and a decrease in self-reported injuries.

\subsubsection{Workers' Opinions}

Researchers also studied how workers perceived their work environment in relation to fall safety. A focus group study of Hispanic workers by Roelofs et al. (2011) [23] found that the workers viewed that supervisor pressure, competition for jobs and intimidation were the reasons for a higher rate of death and injuries to Hispanic construction workers. 
Workers stated that they are pressured from the supervisors to speed up the work and perform in unsafe conditions. This, combined with fear of retaliation for not doing as asked and availability of other workers who can replace them, resulted in Hispanic workers taking more safety risks.

A focus group study of Latino workers in Southern Nevada by Menzel et al. (2010) [24] found that workers reported language barrier, traditional values, poor construction skill, and low health literacy as the reasons for higher risk of death for Latino workers. Latino workers had trouble understanding the safety and health instructions due to limited knowledge of the English language. Lack of poor quality or absence of safety training or equipment and traditional values of masculinity and respect for authority lead to more safety risks to Latino workers.

\subsubsection{Prior Studies in Florida}

Nissen (2004) [25] conducted a pilot study of the safety practices of immigrant workers in South Florida. The study involved a survey of 50 immigrant workers about their training, personal protective safety practices, and employer safety policies and practices, as well as demographic data of workers and employers' non-safety practices (workers' compensation coverage, health care coverage, etc.). The study found that workers face unsafe conditions at work: $16 \%$ of participants had a severe injury during work in last 3 years, $40 \%$ of participants have witnessed a work site accident requiring hospitalization in the previous year. The study also found that workers did not get complete safety training. $50 \%$ or less had received any safety training and non-unionized workers got very less training. The study found a weak statistically significant relationship between the unionized and 
documented status of immigrant workers with the reception of safety training, use of personal protective equipment, and safer employer policies and practices.

Nissen et al. (2008) [26] conducted a study to identify the relationship of unionized status and documented status of immigrant workers with the workers' safety training, practices, and conditions. They performed a survey of 283 immigrant construction workers in south Florida asking questions about their safety training, use of personal protective equipment, and employer safety practices. They found a weak association between the unionized status of immigrant workers with safety training and practices: unionized status had a statistically significant relationship only with the reception of basic ten-hour OSHA training and use of respiratory protection. However, they could not find a statistically significant relationship between documentation, or lack thereof, and safety training and practices of immigrant workers.

\subsection{About OSHA}

An estimated 14,000 workers were killed on the job every year before the formation of OSHA [27]. OSHA was created by the US Congress with the Occupational Safety and Health Act of 1970. Last amended in 2004, the OSH Act states that it is an act "to assure safe and healthful working conditions for working men and women; by authorizing enforcement of the standards developed under the Act; by assisting and encouraging the States in their efforts to assure safe and healthful working conditions; by providing for research, information, education, and training in the field of occupational safety and health; and for other purposes" [27]. OSHA has helped make workplaces safer, worker deaths reduced to 12 per day, at present. 
Section 5 of the $\mathrm{OSH}$ act states the duties of both the employers and the employees. The duty of an employer is described as "each employer shall furnish to each of his employees' employment and a place of employment which are free from recognized hazards that are causing or are likely to cause death or serious physical harm to his employees; shall comply with occupational safety and health standards promulgated under this Act". Similarly, the duty of an employee is described as "each employee shall comply with occupational safety and health standards and all rules, regulations, and orders issued pursuant to this Act which are applicable to his own actions and conduct."

The requirements and criteria for fall protection in construction workplaces are laid out in Subpart M of the Code of Federal Regulations (CFR). It requires employers to provide fall protection to the employees when working at heights of 6 feet or greater above a lower level, or heights less than 6 feet when working near dangerous equipment. The Subpart M covers fall protection as well as falling object protection. It states that employers can provide fall protection using conventional fall protection (guardrail systems, safety net systems, or personal fall arrest systems). Additional fall protection should be provided to workers when the situation demands it.

Following is the list of major sections of Subpart $\mathrm{M}$ which cover fall protection methods and hazards that require protection:

- Construction Activities Requiring Fall Protection

$\checkmark$ Leading Edges - 29 CFR 1926.501(b)(2)

$\checkmark$ Overhand Bricklaying and Related Work - 29 CFR 1926.501(b)(9) 
$\checkmark$ Roofing Work on Low-Slope Roofs - 29 CFR 1926.501(b) (10)

$\checkmark$ Working on Steep Roofs - 29 CFR 1926.501(b) (11)

$\checkmark$ Residential Construction - 29 CFR 1926.501(b) (13)

$\checkmark$ Other Walking or Working Surfaces - 29 CFR 1926.501(b) (15)

- Conventional Fall Protection Systems

$\checkmark$ Guardrail Systems - 29 CFR 1926.502(b)

$\checkmark$ Safety Net Systems - 29 CFR 1926.502(c)

$\checkmark$ Personal Fall Arrest Systems - 29 CFR 1926.502(d)

$\checkmark$ Personal Fall Arrest System Components

$\checkmark$ Positioning Device Systems - 29 CFR 1926.502(e)

$\checkmark \quad$ Fall Restraint Systems

- Additional Fall Protection Systems

$\checkmark \quad$ Warning Line Systems - 29 CFR 1926.502(f)

$\checkmark$ Controlled Access Zones - 29 CFR 1926.502(g)

$\checkmark$ Safety Monitoring Systems - 29 CFR 1926.502(h)

- Other Hazards that Require Fall Protection

$\checkmark$ Hoist Areas - 29 CFR 1926.501(b)(3)

$\checkmark$ Holes - 29 CFR 1926.501(b)(4) 
$\checkmark$ Ramps, Runways, and Other Walkways - 29 CFR 1926.501(b)(6)

$\checkmark$ Excavations - 29 CFR 1926.501(b)(7)

$\checkmark$ Dangerous Equipment - 29 CFR 1926.501(b)(8)

$\checkmark \quad$ Wall Openings - 29 CFR 1926.501(b)(14)

- Protection from Falling Objects

$\checkmark$ Guardrails - 29 CFR 1926.502(j)(5)

$\checkmark$ Overhand Bricklaying and Related Work - 29 CFR 1926.502(j)(6)

$\checkmark$ Roofing Work - 29 CFR 1926.502(j)(7)

$\checkmark$ Toeboards - 29 CFR 1926.502(j)(1) through (4)

$\checkmark$ Canopies - 29 CFR 1926.502(j)(8)

- Fall Protection Plans

- Fall Protection Training

\subsection{Construction Falls Statistics}

\subsubsection{Fatal Work Injuries by Industry}

A fatal injury report by the US Bureau of Labor Statistics states that the construction industry had the highest number of deaths, 991, in the private industry sector in 2016. Figure 1 below shows the breakdown of deaths in the private industry. 


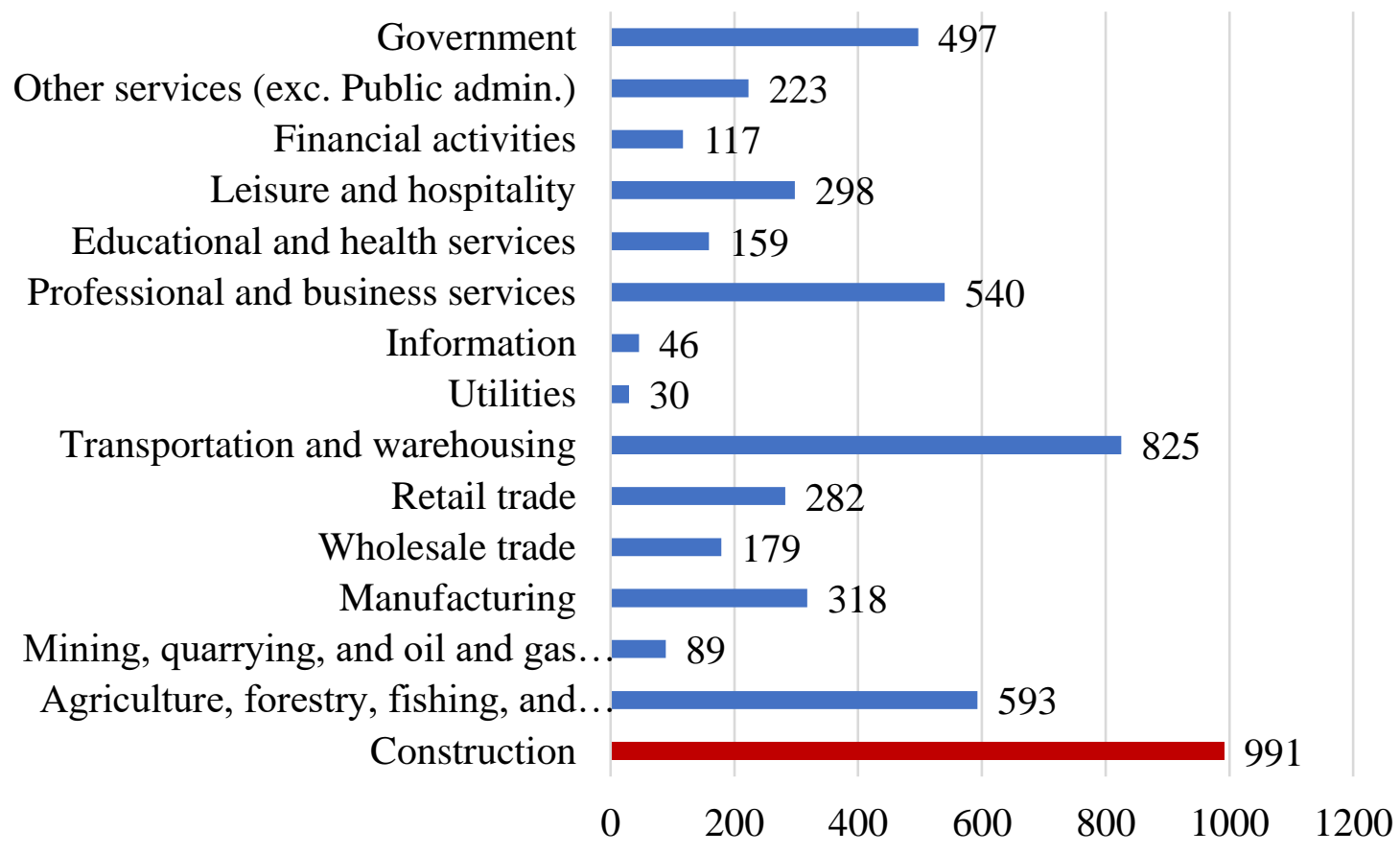

Figure 1: Number of fatal work injuries in the US, 2016

\subsubsection{Fatal Falls to Lower Level by Industry}

The construction industry had 370 fatal falls to a lower level in 2016, from 350 in 2015 [28]. Compared to the 2011 data, this was a $45 \%$ increase. In six years, 2011-2016, the construction industry was accountable for more than half of fatal falls to the lower level. All other industries combined, however, only had a $10 \%$ increase in the same period. Figure 2 below shows the detailed breakdown of falls to a lower height from 2011 to 2016. 
- Construction

- Trade, transportation, and utilities

- Manufacturing

- Government
- Professional and business services

- Natural resources and mining

all other private industries

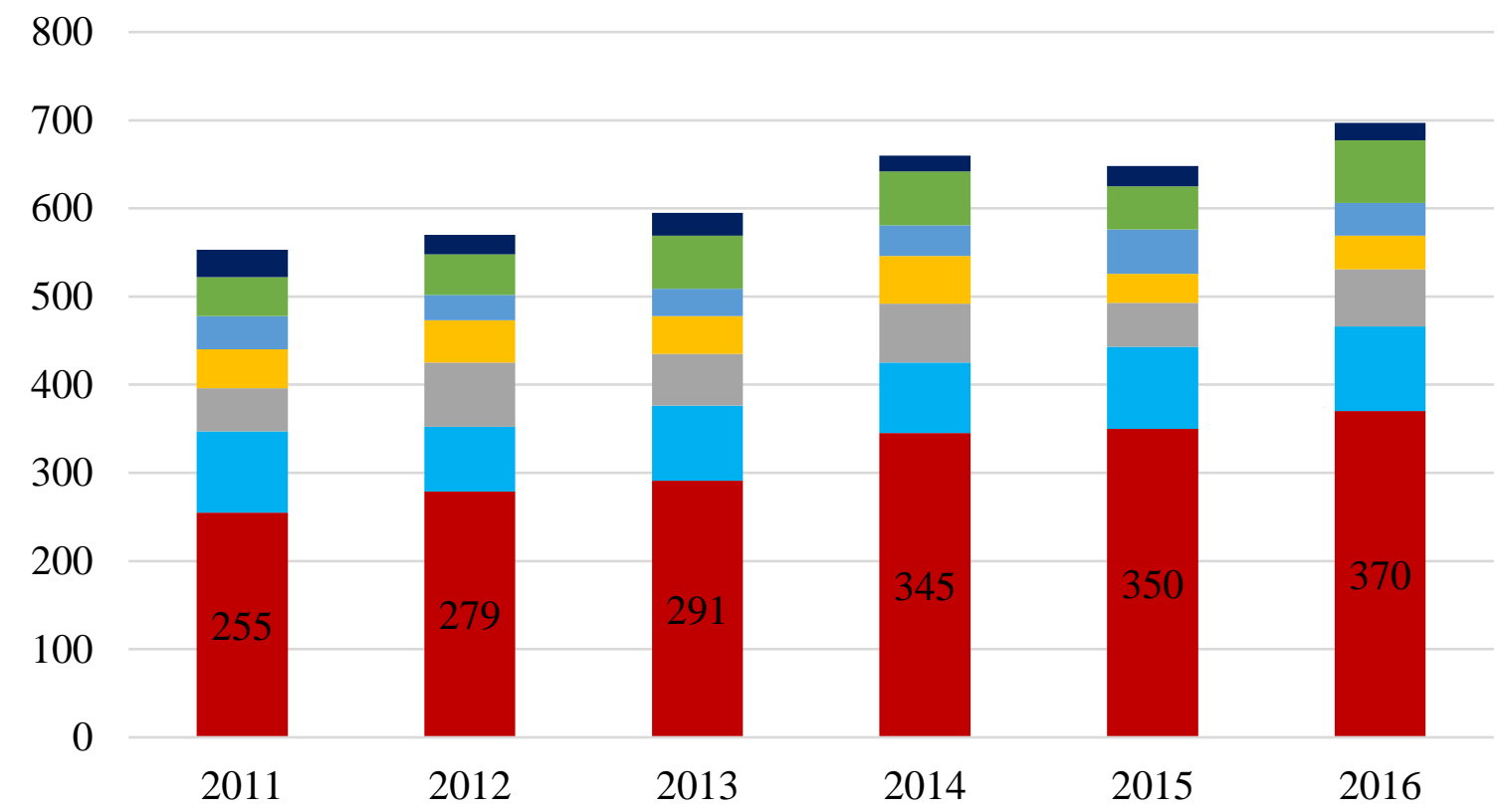

Figure 2: Fatal work-related falls to a lower level by industry, 2011-16

\subsubsection{Fatal Falls by Source and Height of the Fall}

In falls to lower height category, ladders and roofs caused the most deaths over the same six-year period from 2011 to 2016, 836 and 763 respectively [28]. The highest number of deaths, 685, occurred from heights above 30 feet during that period. Figure 3 below shows the breakdown of falls to a lower height by source and height of the fall from 2011-2016. 
Height not specified

Under 6 feet

6-10 feet

$11-15$ feet

16-20 feet

$21-25$ feet

26-30 feet

Over 30 feet

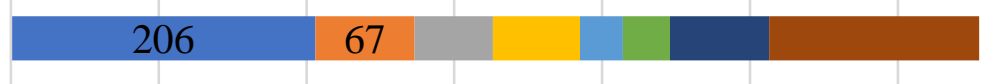

$87 \quad 0$

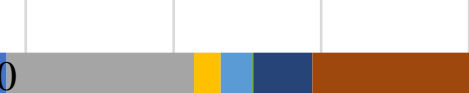

174

41
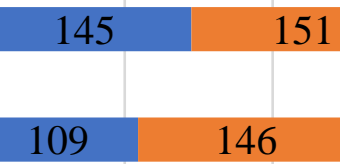

146

$59 \quad 130$

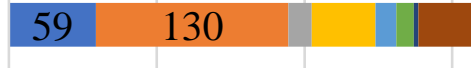

27100

$29 \quad 127$

$0 \quad 100 \quad 200 \quad 300$

$400 \quad 500$

$600 \quad 700$

- Ladders

Roofs

- Vehicles

Scaffolds, staging $\square$ Machinery

- Trees

Stairs, steps $\quad$ All other sources

Figure 3: Fatal work-related falls to a lower level by source and height of fall, 2011-16

\subsubsection{Falls to Lower Level}

In 2016 alone, 693 fatal falls to lower level occurred which was an increase of 8 percent from 2015 [29]. Nearly half (47\%) of those falls were from a height of less than 15 feet (Figure 4). Among the fatal falls from known heights, one in five fell from more than 30 feet in height. Figure 4 below shows the breakdown of the falls to lower height in 2016. 


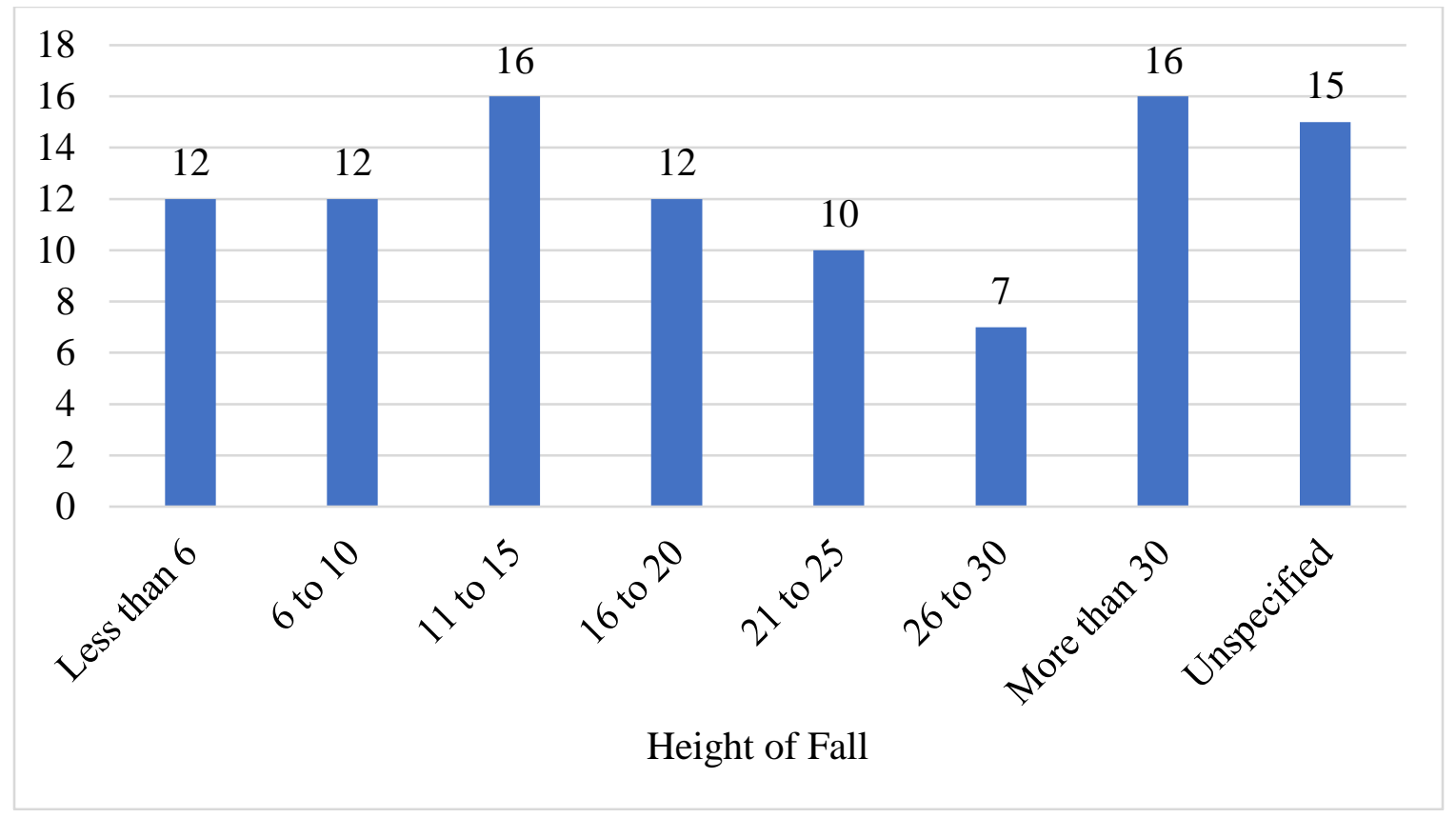

Figure 4: Percent of fatal falls to lower level by height of fall, 2016

\subsubsection{Falls VS Other Fatalities}

According to the 2017 CWPR (The Center for Construction Research and Training) data report [30], the rate of increase of fatal falls was higher than the rate of other fatalities in construction between 2011 and 2015 (Figure 5). While other fatalities increased by $26.1 \%$ between 2011 and 2015, fatal falls in construction increased by $36.7 \%$, from 269 to 367 during the same period. 
Falls vs Other Fatalities in Construction, 2011-2015

1200

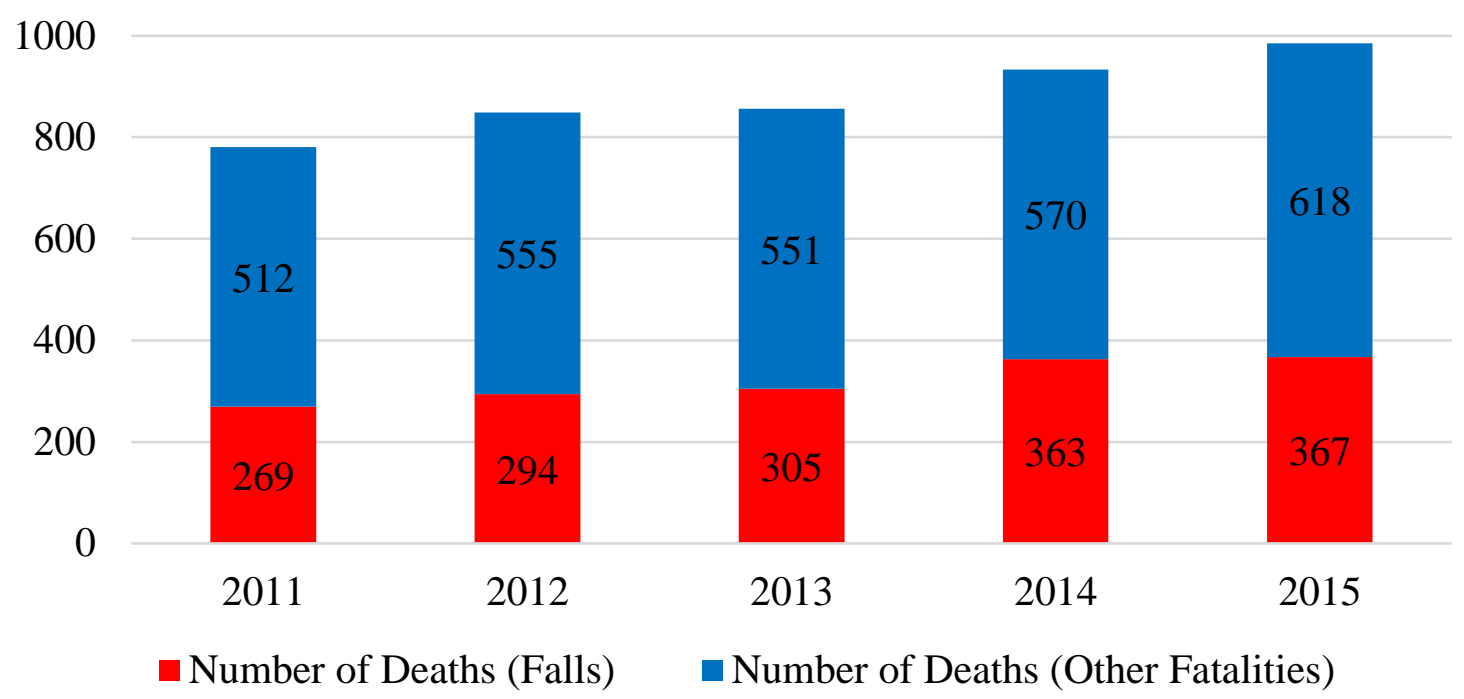

Figure 5: Falls vs Other Fatalities in Construction, 2011-2015

\subsubsection{Falls by Construction Trades}

According to the same report, laborers had the highest number of deaths, 323, among the construction trades between 2011 and 2015 (Figure 6). Roofers were second with 291 fatalities during the same period. The chart below shows the breakdown of number of fatalities and rate per 100,000 Full-Time Equivalent Workers(FTEs) of different construction trades in the US between 2011 and 2015. The FTEs were estimated by the 
CWPR which might not represent the calculations done by BLS.

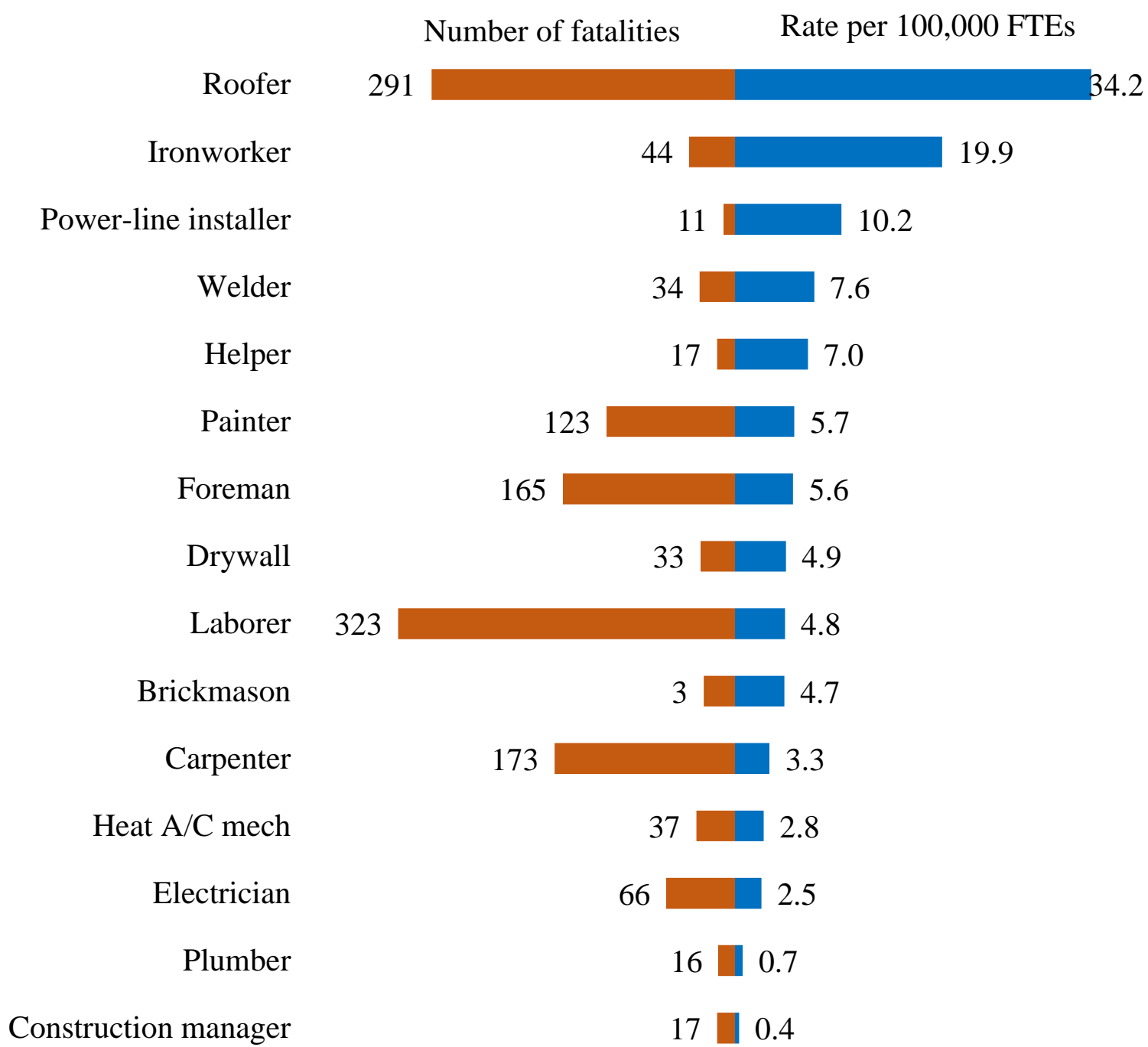

Figure 6: Work-related fatalities from falls to a lower level in US construction, 20112015

\subsubsection{Fatal Injuries in Private Industry in Florida}

In Florida, 286 fatal work injuries occurred in private industry sector in 2016, about a $17 \%$ increase from 243 deaths in 2015 [3]. The highest number of deaths, 76, was in the construction industry in 2016 (Figure 7). Figure 7 below shows the breakdown of the fatal 
injuries in Florida in 2015 and 2016. The fatalities for some categories were missing, and the categories did not add up to the total in the data provided by the BLS.

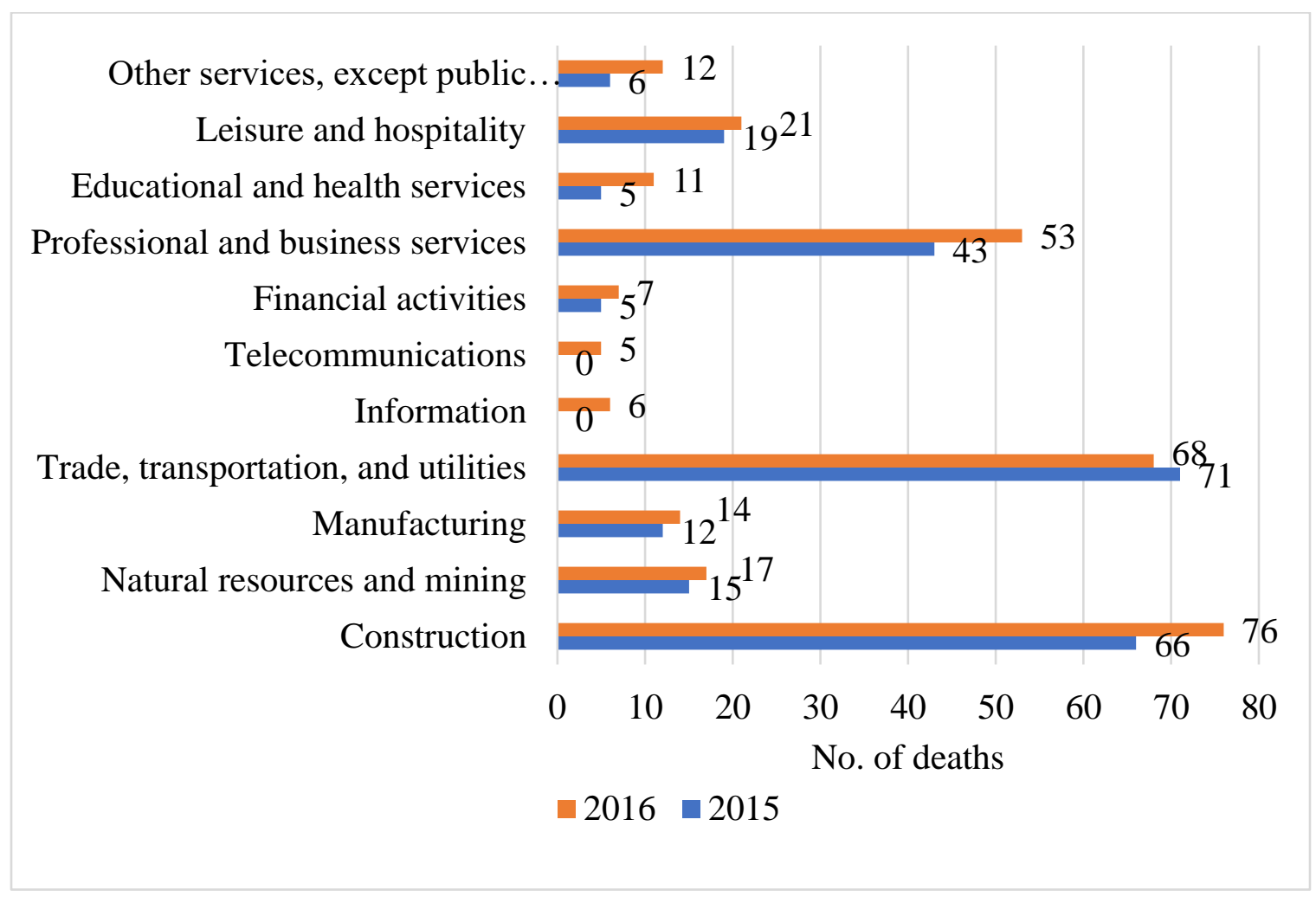

Figure 7: Fatal Injuries in Private Industry in Florida, 2015-16

\subsubsection{Fatal Injuries in Construction and Extraction in Florida}

In Florida, 68 fatal injuries occurred in construction and extraction occupation in 2016, about a $21 \%$ increase from 56 deaths in 2015 (Figure 8). Roofers suffered the most deaths, 11, followed by 10 deaths for laborers and 9 for carpenters. Figure 8 below shows the breakdown of the deaths in various subcategories in 2015 and 2016. 
Other construction and related workers

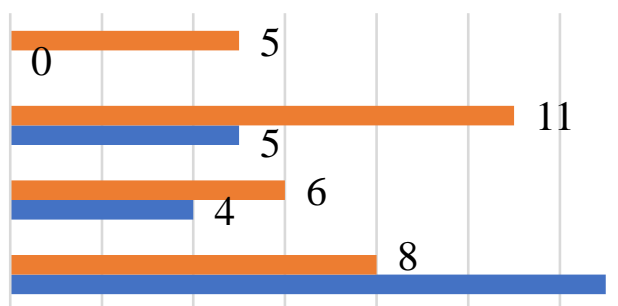

Construction equipment operators

Construction laborers

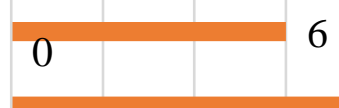

6

Carpenters

Supervisors

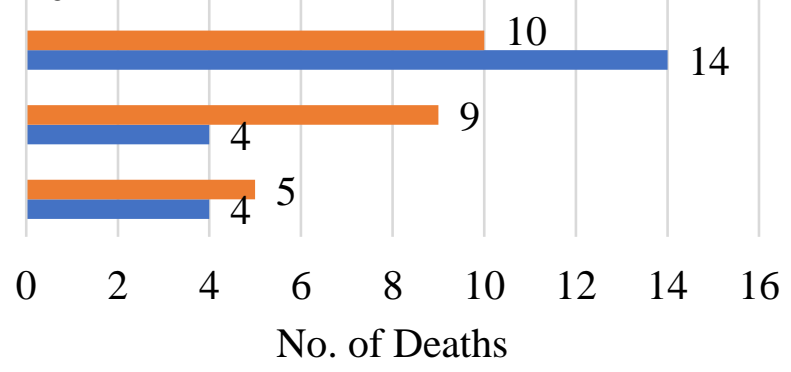

$\square 2016 \square 2015$

Figure 8: Fatal injuries in Construction and extraction occupations in Florida, 2015-16

\subsubsection{Fatal Injuries in the US vs. Florida}

In Florida, worker fatalities due to falls, slips or trips increased from 52 in 2015 to 64 in 2016. Falls, slips, or trips caused $21 \%$ of fatal workplace injuries in Florida in 2016, which is greater than the national average (Figure 9). Fall, slips, or trips were responsible for $16 \%$ of fatal work injuries in the US. 


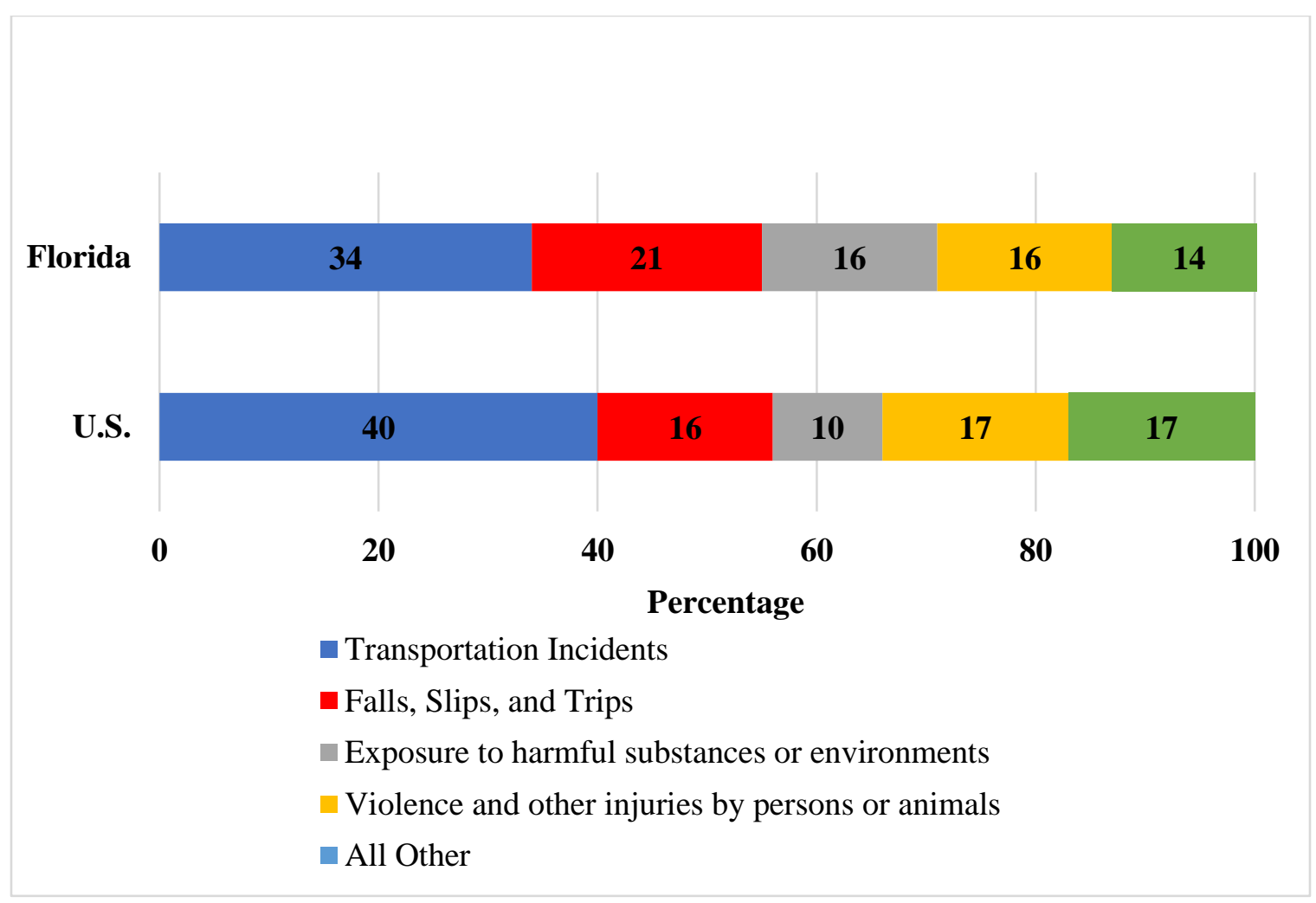

Figure 9: Fatal occupational injuries by event or exposure, US and Florida - 2016

\section{Methodology}

The overall methodology steps employed in this research is represented by Figure 10. This section discusses three of those steps: questionnaire formulation, data collection, and data analysis. 


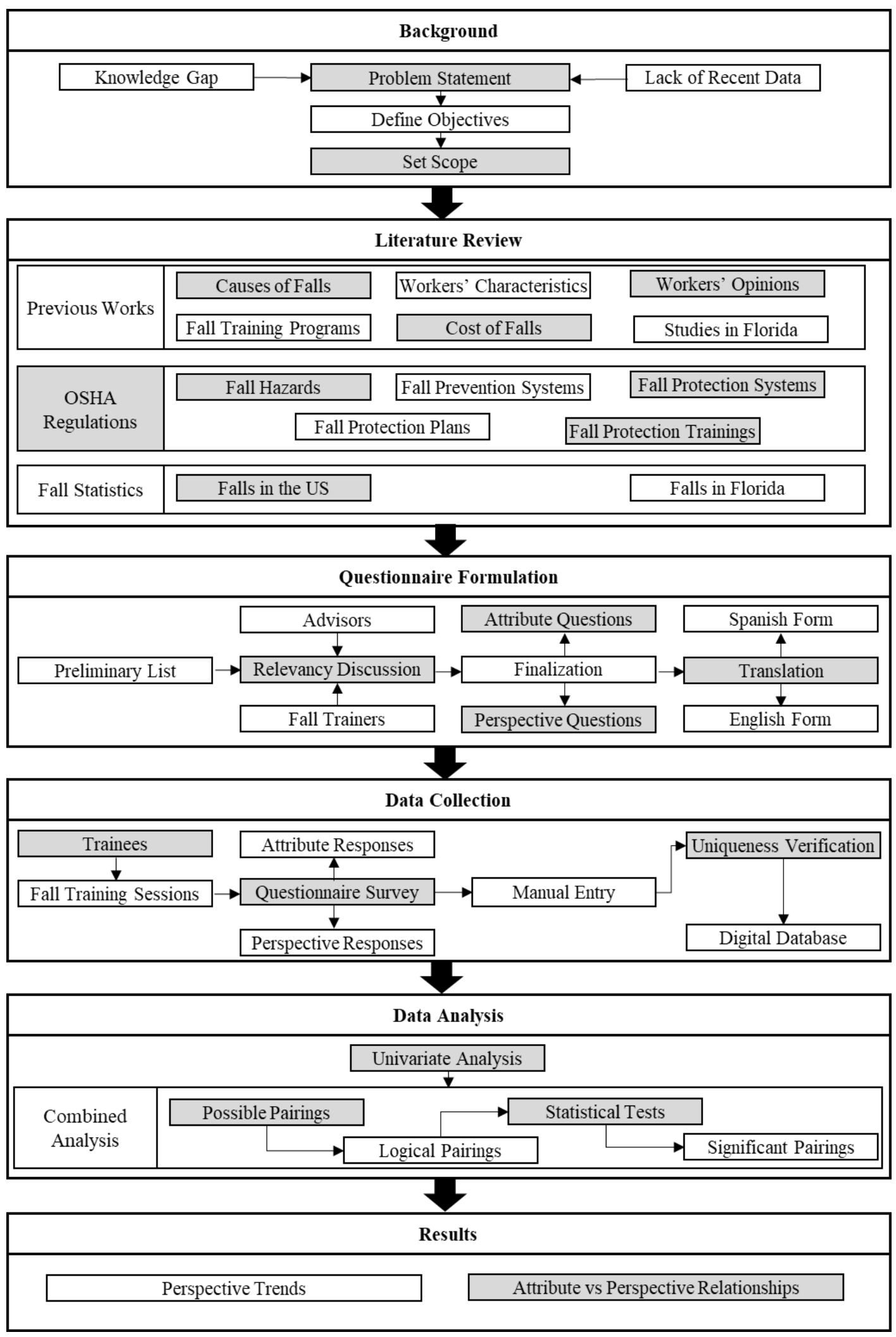

Figure 10: Research Methodology 


\subsection{Questionnaire Formulation}

\subsubsection{Preliminary List}

An extensive literature review of existing research and books on fall prevention and safety related topics was conducted to come up with the information used in the survey questionnaires, which are discussed in the later section. Based on the literature review, a list of fall-related questions was prepared.

\subsubsection{Relevancy Discussion}

The initial list of questions were taken to the advisor and the recommendations were noted. A discussion was conducted with the safety instructor of the fall training program who gave his input on the pertinence of the questions.

\subsubsection{Finalization}

After a few discussion sessions, a final list of questions was set which covered the important safety-related questions which asked. The final questionnaire asked the participants to provide responses about their attributes as well as their opinions of different aspect of fall safety relating to themselves, their employers and their coworkers. The final questionnaire had 22 questions which were divided into 4 sections. The first section has attribute related questions which asked the participants about their trade, age, years of experience and education level. The second section asked the participants about the safety culture of their employers: whether their employers provided safety training, adequate safety equipment and so on. The third section asked the participants about their own safety conduct: whether they felt they had adequate knowledge of fall hazards and safety measures, how often they encountered fall hazards on the job site and so on. The fourth 
section asked the participants about their co-workers' safety behavior and its influence: whether their coworkers followed safety procedures, the effect of co-workers' safety behavior in their own safety conduct and so on.

\subsubsection{Translation}

The fall protection training sessions were conducted in English and Spanish languages. The details of the fall training sessions are listed in a later section. The questionnaire was first prepared in English and then converted to Spanish using Google Translate. The accuracy of translation was verified, and corrections were made after review from the Safety Instructor of the fall training program who was fluent in both Spanish and English.

\subsection{Data Collection}

\subsubsection{Fall Training Sessions}

The fall protection training was conducted under the OSHA's (Occupational Safety and Health Administration) Susan Harwood Training Grant program. A three-hour long training titled "Fall Protection Training" was conducted in English and Spanish language sessions in various locations including FIU Engineering Center and FIU at I-75 Campus. Training materials included a PowerPoint presentation, safety equipment demonstration, Fall Prevention handouts and survey questionnaires.

\subsubsection{Questionnaire Survey}

The participants of the training were asked to fill 5 different survey forms. The first form (Form-1) had personal information related questions which were used as an identification and to maintain unique entry from the participants. The second form (Form-

2) had questions about safety environment, safety behavior and safety experience of the 
participants. The third form (Form-3) had fall safety-related questions designed to understand the safety knowledge of participants before they took the training. Participants were asked to fill those three forms before the training started. The fourth form (Form-4) provided to the participants, which was optional so that they could note the important facts from the training and take it with them for future use. The fifth form (Form-5) has the same questions as in form three which the participants filled after the training. The intention was to compare the safety knowledge before and after the training. The sixth form (Form-6) had questions about the evaluation of the training itself which the participants filled at the end of the training. Participants were asked to write their names on all the forms so that their answers on different forms could be associated.

The training sessions and subsequent data collection through survey forms were done in 4 different monthly quarters in 2017-18. During the training period, December/ 2017 September/2018, we trained a total of 1009 individuals. There was a total of 50 training sessions conducted, 38 in English with a total of 729 participants (about 78\%), and 12 in Spanish with a total of 219 participants (about 22\%). Table 4: List of Fall Training Sessions Conducted below shows the details of the training program during the training period.

Table 4: List of Fall Training Sessions Conducted

\begin{tabular}{|c|c|c|c|}
\hline No & Date/Time & Language & Attended \\
\hline 1 & $12 / 2 / 20178: 30$ & English & 19 \\
\hline 2 & $12 / 9 / 20178: 30$ & Spanish & 16 \\
\hline 3 & $12 / 14 / 201713: 30$ & English & 15 \\
\hline 4 & $12 / 16 / 20178: 30$ & Spanish & 4 \\
\hline 5 & $1 / 13 / 20188: 30$ & English & 21 \\
\hline 6 & $1 / 20 / 20188: 30$ & Spanish & 8 \\
\hline 7 & $1 / 27 / 20188: 30$ & English & 18 \\
\hline 8 & $2 / 3 / 20188: 30$ & Spanish & 10 \\
\hline
\end{tabular}




\begin{tabular}{|c|c|c|c|}
\hline No & Date/Time & Language & Attended \\
\hline 9 & $2 / 7 / 20188: 30$ & English & 40 \\
\hline 10 & $2 / 10 / 2018$ 8:30 & Spanish & 32 \\
\hline 11 & $2 / 17 / 20188: 30$ & English & 8 \\
\hline 12 & $2 / 24 / 20188: 30$ & English & 8 \\
\hline 13 & 2/27/2018 8:00 & English & 18 \\
\hline 14 & 3/10/2018 8:30 & English & 17 \\
\hline 15 & $3 / 31 / 20188: 30$ & English & 14 \\
\hline 16 & 4/3/2018 18:00 & English & 46 \\
\hline 17 & 4/5/2018 17:30 & Spanish & 7 \\
\hline 18 & $4 / 12 / 20188: 30$ & English & 9 \\
\hline 19 & $4 / 19 / 2018$ 17:30 & Spanish & 3 \\
\hline 20 & $4 / 21 / 20188: 30$ & English & 25 \\
\hline 21 & $4 / 23 / 20188: 30$ & Spanish & 43 \\
\hline 22 & $4 / 24 / 20188: 30$ & English & 26 \\
\hline 23 & $4 / 25 / 20188: 30$ & English & 40 \\
\hline 24 & 4/26/2018 8:30 & English & 31 \\
\hline 25 & 4/28/2018 8:00 & English & 8 \\
\hline 26 & 4/28/2018 14:00 & Spanish & 7 \\
\hline 27 & 5/1/2018 8:00 & English & 29 \\
\hline 28 & 5/2/2018 8:00 & English & 32 \\
\hline 29 & 5/3/2018 17:30 & English & 7 \\
\hline 30 & 5/8/2018 8:00 & English & 44 \\
\hline 31 & 5/9/2018 18:00 & English & 39 \\
\hline 32 & $5 / 24 / 201817: 30$ & Spanish & 18 \\
\hline 33 & 7/10/2018 17:30 & English & 25 \\
\hline 34 & 7/28/2018 8:00 & English & 3 \\
\hline 35 & $7 / 31 / 20187: 30$ & Spanish & 54 \\
\hline 36 & 8/11/2018 8:30 & English & 6 \\
\hline 37 & 8/18/2018 8:30 & English & 26 \\
\hline 38 & $8 / 21 / 201817: 30$ & English & 2 \\
\hline 39 & 8/29/2018 17:00 & English & 37 \\
\hline 40 & 8/30/2018 7:30 & English & 22 \\
\hline 41 & 9/8/2018 8:30 & English & 3 \\
\hline 42 & 9/11/2018 18:00 & English & 16 \\
\hline 43 & 9/12/2018 18:00 & English & 10 \\
\hline 44 & 9/12/2018 18:00 & Spanish & 17 \\
\hline 45 & 9/12/2018 18:00 & English & 20 \\
\hline 46 & 9/12/2018 18:00 & English & 21 \\
\hline
\end{tabular}




\begin{tabular}{|c|c|c|c|}
\hline No & Date/Time & Language & Attended \\
\hline 47 & $9 / 13 / 201818: 00$ & English & 35 \\
\hline 48 & $9 / 18 / 201818: 00$ & English & 11 \\
\hline 49 & $9 / 19 / 201818: 00$ & English & 34 \\
\hline 50 & $9 / 22 / 201818: 00$ & English & 5 \\
\hline & Total & & $\mathbf{1 0 0 9}$ \\
\hline
\end{tabular}

Out of the 1009 participants in the training, 847 participants filled and submitted form2 which is utilized in this study.

\subsubsection{Manual Entry}

Our research uses the data obtained from the second form or Form-2 mentioned above for the analysis. The individual responses from the form-2, along with corresponding responses of all other forms were read and carefully entered into the "Google Forms" software to create a digital record of the data. The entry of five forms from one individual required about 12 minutes. The manual entry of all five forms took about 200 hours in total.

\subsubsection{Uniqueness Verification}

The participants were asked to provide their names in every form. Their names were used as an identifier for their responses across the forms. The names and date of birth of the participants were used to identify the repeated entry from a single participant and duplicate entries were removed.

\subsubsection{Digital Database}

Finally, a digital database free form repeated entries was obtained. The digital data was then transferred to "MATLAB," and the options in the individual questions were converted into numbers. A count of the responses for each question in the Form-2 was made with 
MATLAB. MATLAB was also used to count the responses for two-question combinations for the combined analysis part which is discussed in a later section.

\subsection{Data Analysis}

Descriptive and Inferential statistics were used to analyze the collected data. Descriptive statistics is the analysis of data that helps to reduce the data into a simpler summary. Descriptive statistics allows us to look at our data and see if any pattern emerges without conducting complex statistical calculations. Accompanied by simple graphical analysis, descriptive statistics help us identify the basic features of our study data. The general methods used for descriptive analysis are measures of central tendency and measures of the spread of the data.

Inferential statistics is the analysis of data outside the basic information provided by the data. We use inferential statistics to analyze sample data to deduce the characteristics of the population. The general methods used for inferential statistics are an estimation of parameters and hypothesis testing.

The data collected for this research were of nominal and ordinal scales. Nominal variables classify observations into discrete categories [31]. An individual observation of a nominal variable can be expressed as a word, not a number. In our research, we ask participants their role in the construction industry. Their responses to the question: roofer, laborer, electrician, and so on, are nominal variables. Nominal variables are generally summarized as proportions or percentages.

Ordinal variables are also called ranked variables. The individual observations for ordinal variables can be put in order from smallest to largest. For example, in our research, 
we ask the participants how strict their employers about safety measures. Their responses to the question: Very strict, Strict, Neutral, Lenient, and Very lenient, are ordinal variables.

\subsubsection{Univariate Analysis}

Univariate analysis is the simplest way of analyzing data with only one variable. It does not show relationships but describes the data by summarizing the data and finding basic patterns in the data.

We asked 22 different questions in the Form-2 to the participants of the training which are used for analysis in this research. The univariate analysis of the data obtained for those 22 questions is presented below.

\subsubsection{Q1. "What is your role in the construction site?"}

We placed the 847 participants who filled the Form-2 into 11 categories according to their response to this question. The categories include nine different construction trades which have at least 10 participants each (Figure 11). Participants were also allowed to write their trades if they could not find an appropriate match on the given list. Their written response was evaluated to place them in one of the nine categories. Participants who did not answer this question were placed in the "Unanswered" category. The participants whose responses were ambiguous and did not have enough frequency to meet the threshold value of 10 , were placed in the "Others" category.

The category with most participants was "Electricians." Electricians outnumbered the next three large trades: plumbers, laborers, and supervisors combined. 


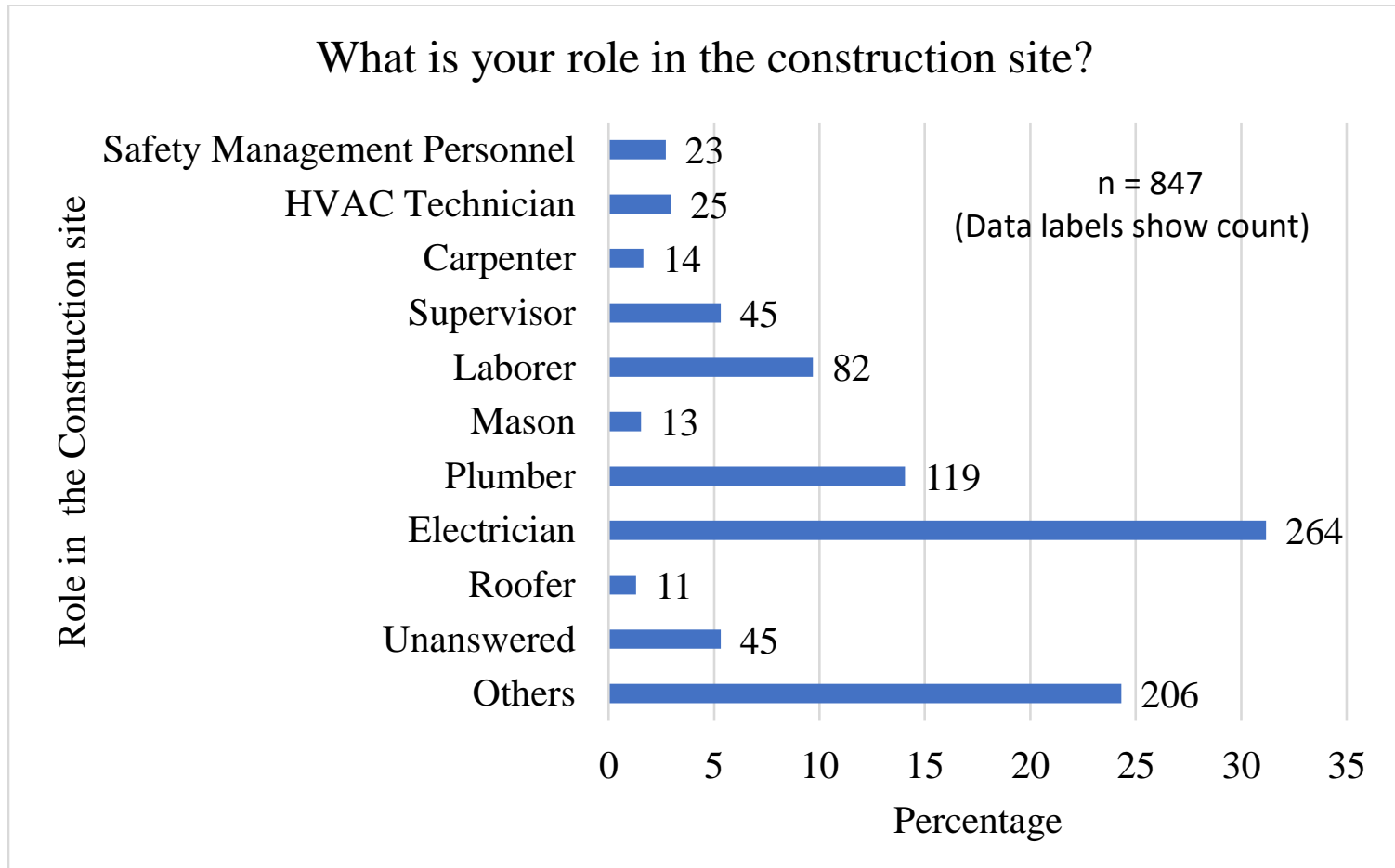

Figure 11: Role in the construction site in Percentage

\subsubsection{Q2. "How many years of experience do you have in the construction industry?"}

We placed 827 participants into seven categories according to their response to this question: 6 categories starting from zero experience to more than 20 years of experience, and an "unanswered" category for those who do not respond to the question.

We observed that beginners with less than 2 years of experience had the highest participation in the training (Figure 12). The number of participants had a decreasing trend as their years of experience increased. We also had about $8 \%$ of participants who answered they had zero experience in the construction industry. We assume those responses were from the participants who had just started their job and did not have even a year of 
experience and the FIU students who attended the training session open to them.

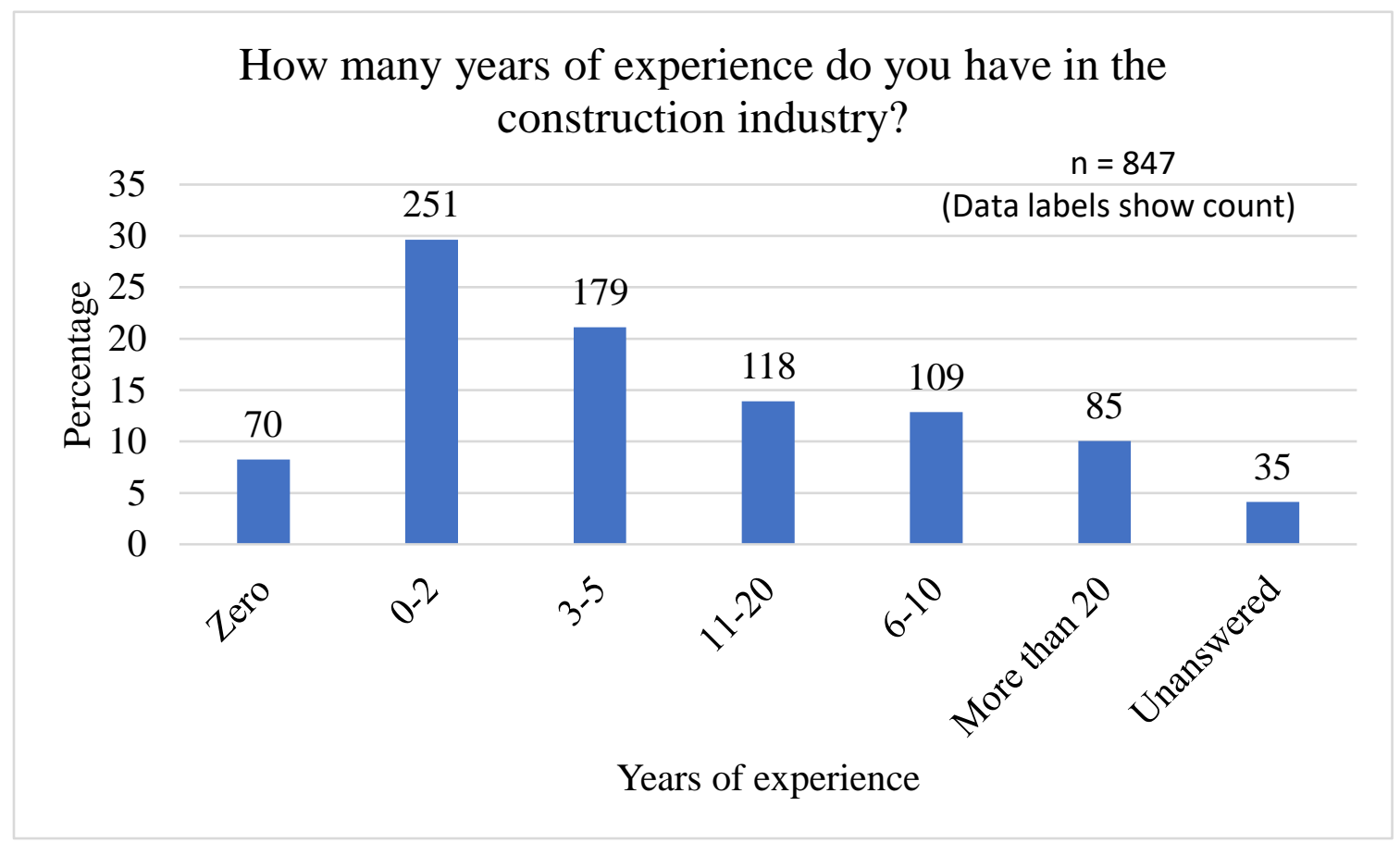

Figure 12: Years of Experience by Percentage

\subsubsection{Q3. "How old are you?"}

We placed 827 participants in six categories according to their response to this question. We had five categories starting from less than 18 years of age to more than 65 years of age. We put participants who did not respond to another category named "unanswered".

We observed that middle-aged participants, 30 to 49 years of age, had the highest number of responses: nearly $50 \%$ of total responses(Figure 13). There were about 1.5 times younger (29 years or less) participants than older participants (50 years or more). 


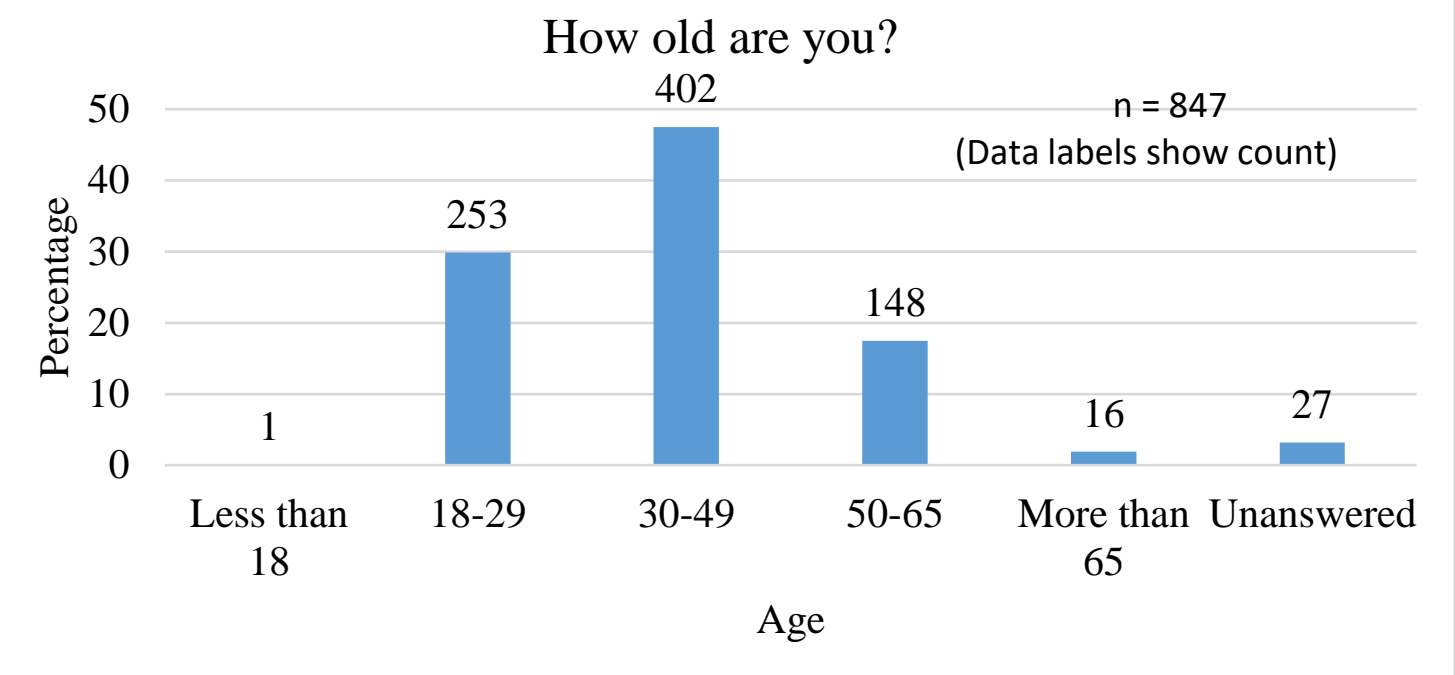

Figure 13: Age by Percentage

\subsubsection{Q4. "What is your level of education?"}

We placed the 847 participants into five categories according to their response. The largest number of participants said they had school education who were more than participants with a college degree and undergraduate degree combined(Figure 14). The "Graduate degree" had an unexpectedly high amount of response. We assume those who choose that response were largely students in graduate level who misinterpreted the option. 


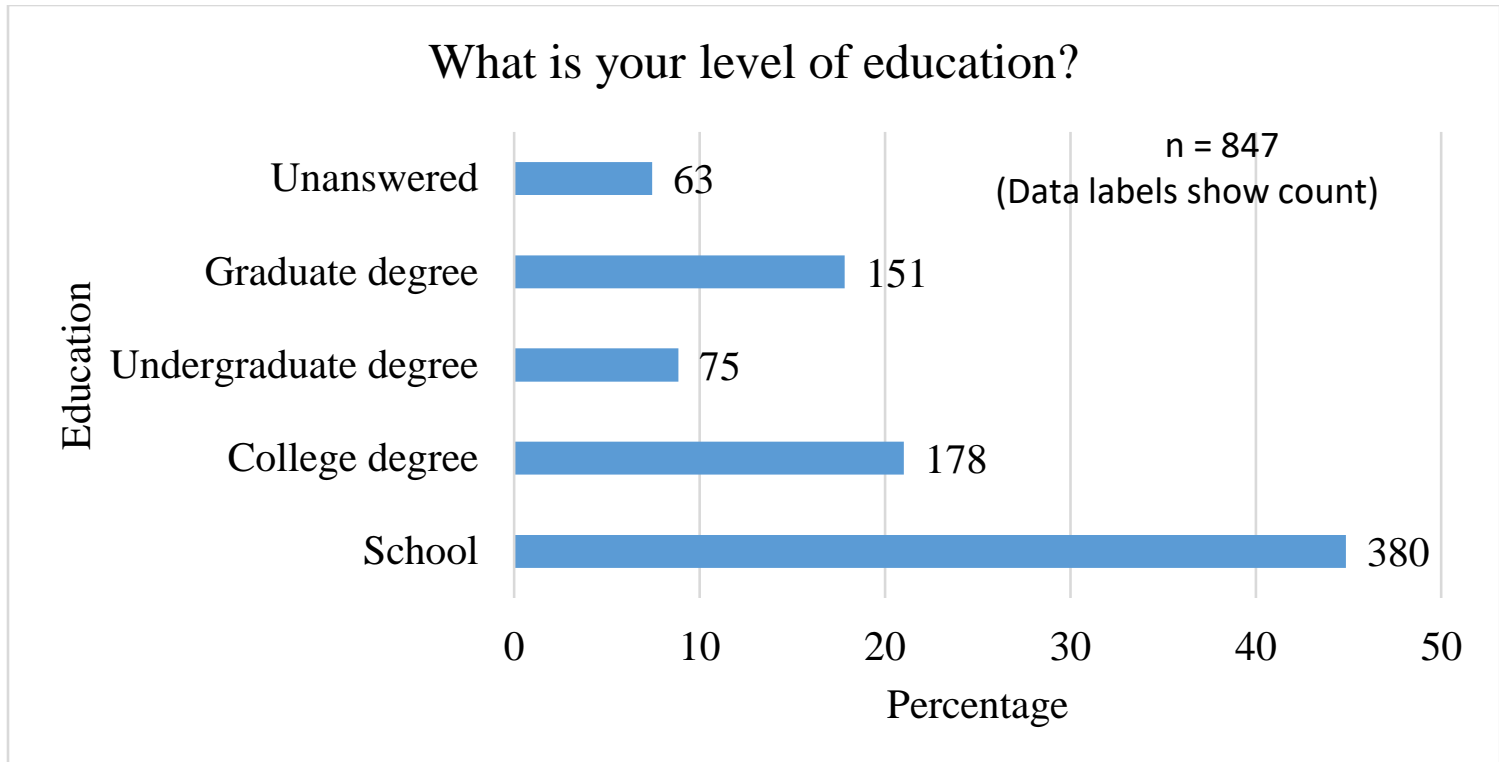

Figure 14: Level of education by Percentage

\subsubsection{Q5. " How often do you need a safety training certificate to get a job?"'}

We placed 847 participants in six categories according to their response. About $48 \%$ of participants said they always or most of the time needed safety certificate to get a job compared to $38 \%$ who said they never or only sometimes needed a safety certificate(Figure 15). We observed that construction professionals had some leniency in terms of needing a safety training certificate to get a job. 


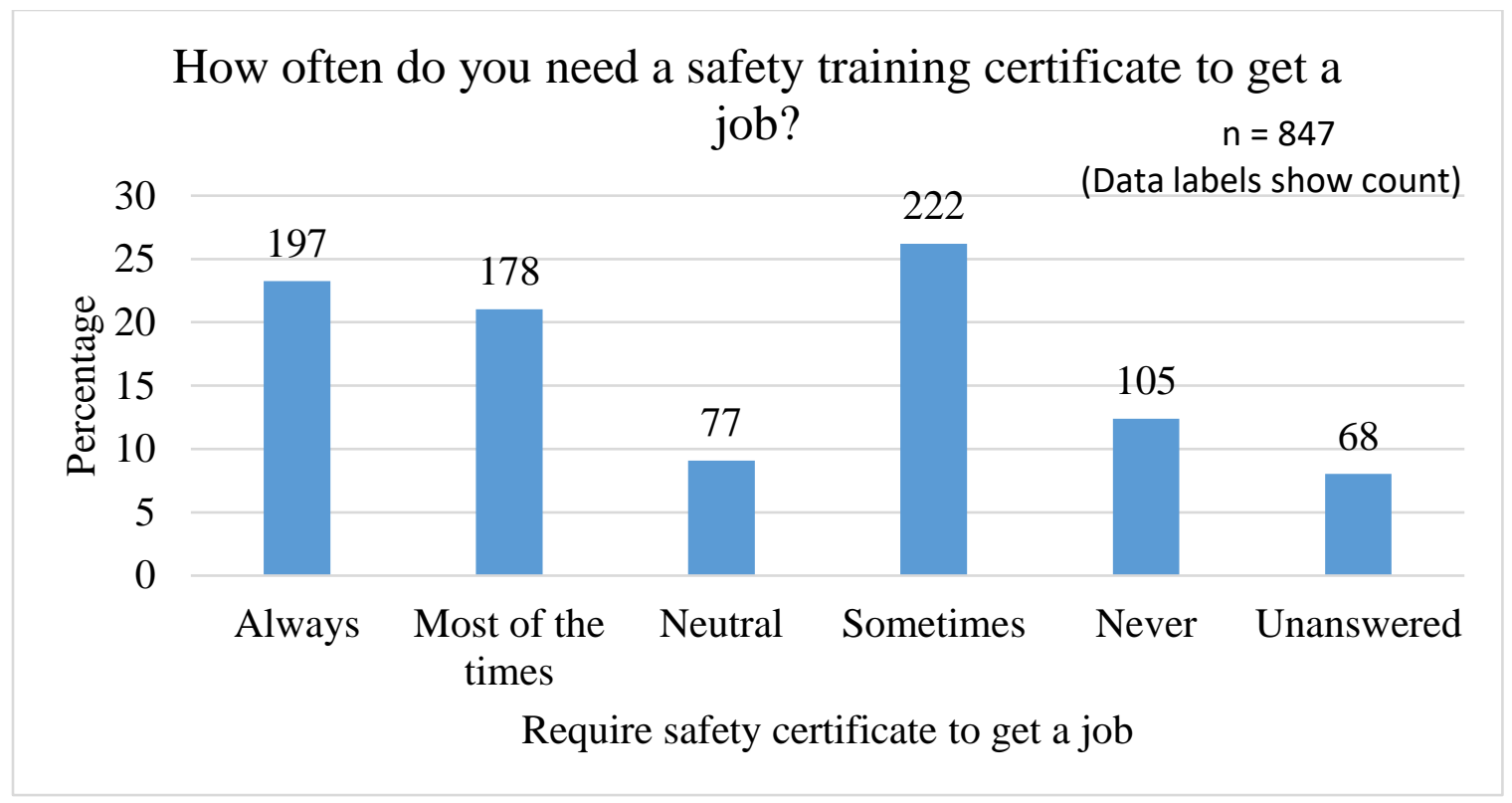

Figure 15: Requisite of a safety training certificate to get a job in Percentage

\subsubsection{Q6. "Does your employer provide training for safety on site?"}

We place the 847 participants into the four categories: "Yes," "No," "Neutral," and "Unanswered," according to their response to this question. About three-fourths of the participants said they were provided safety training on site(Figure 16). 


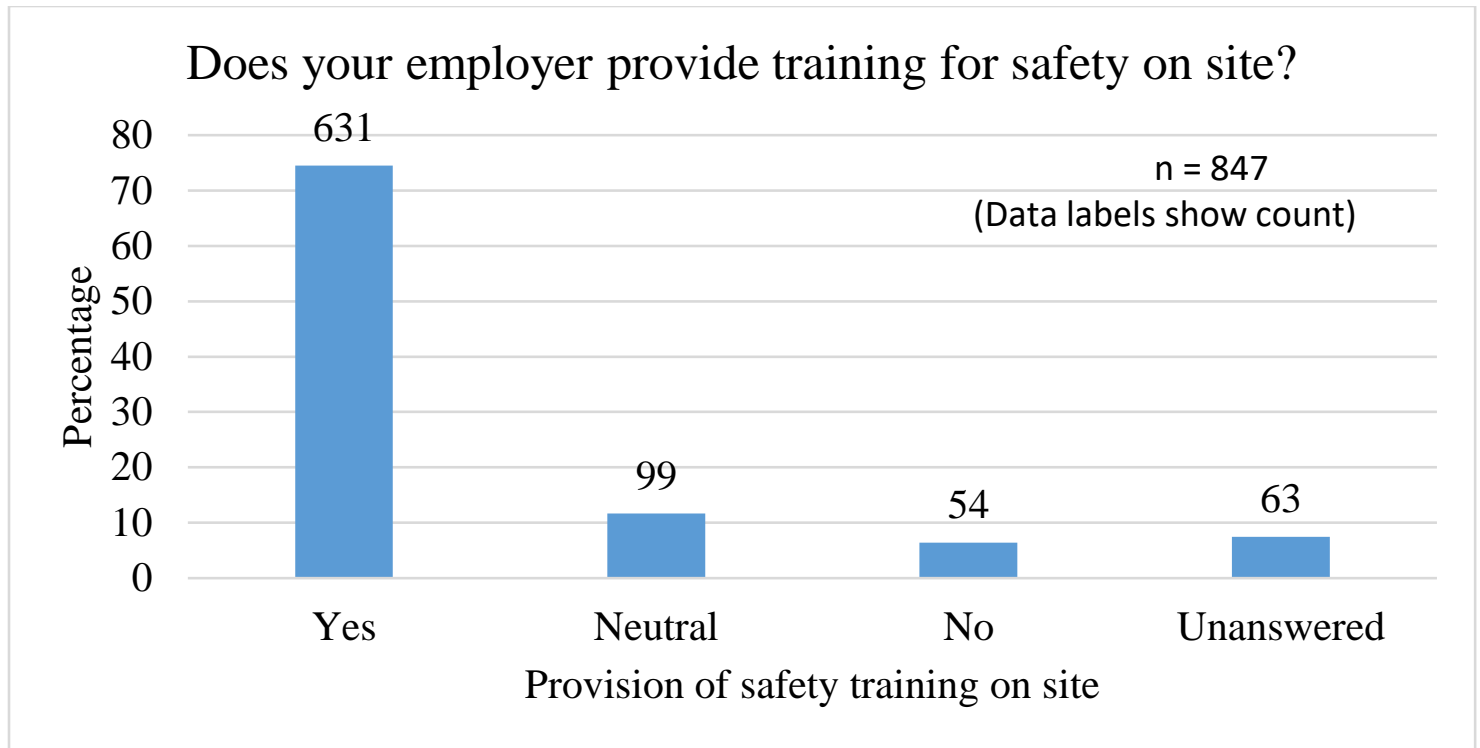

Figure 16: Provision of safety training on site by Employer in Percentage

\subsubsection{Q7. "If Yes, what kind of safety training? SELECT ALL THAT APPLY."}

We gave participants five categories to choose from: "Verbal Instructions," "Posters on site," "Safety manuals," "Audio-visual presentation" and "Not Listed Above." We placed the 847 participants into those categories according to their responses and added one more category "All four options" for participants who choose the first four options.

We observed that about two-thirds of the participants said they were provided verbal instruction as safety training measure(Figure 17). The audio-visual presentation was the least chosen measure for safety training. Only one in five participants said that they were provided all four safety training measures: verbal instructions, posters on site, safety manuals and audio-visual presentation. Among the participants who chose "not listed above," safety meeting at the site was the most common response as an additional training measure. 


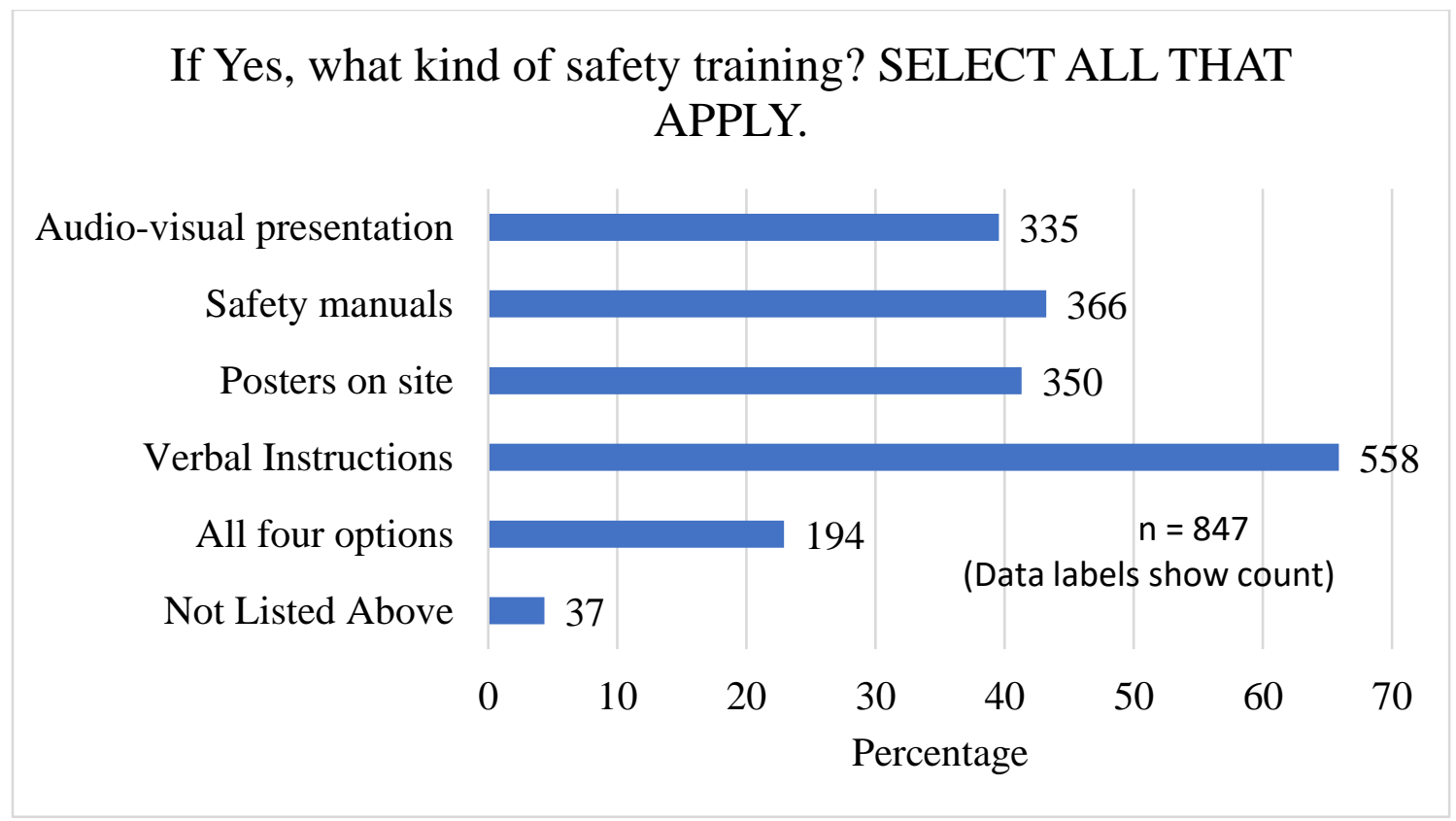

Figure 17: Type of safety training provided in Percentage

\subsubsection{Q8. "What do you think about the adequacy of safety equipment provided by your employers?"}

We placed the 847 participants into the four categories: "Yes," "No," "Neutral," and "Unanswered," according to their response to this question. About three-fourths of the participants said that all workers were provided adequate safety equipment by their employers(Figure 18). 


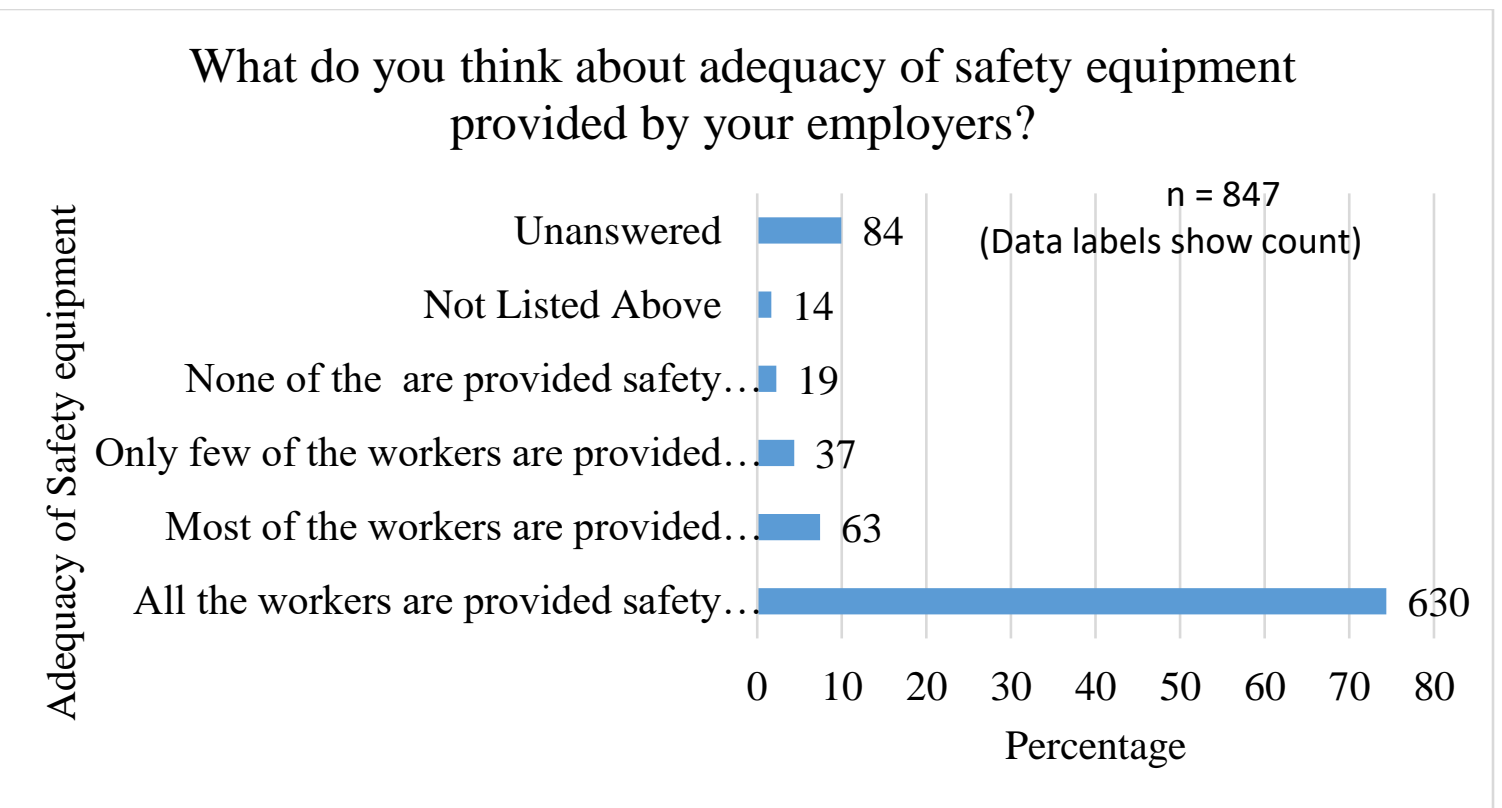

Figure 18: Adequacy of Safety equipment provided by the employers in Percentage

\subsubsection{Q9. "How strict or lenient is your employer about safety measures?"}

We placed the 847 participants into six groups according to their response to this question. About half of the participants said their employers were very strict(Figure 19). Combined with participants who responded that their employers were strict, nearly $80 \%$ of participants had employers who were strict about the safety measures. 


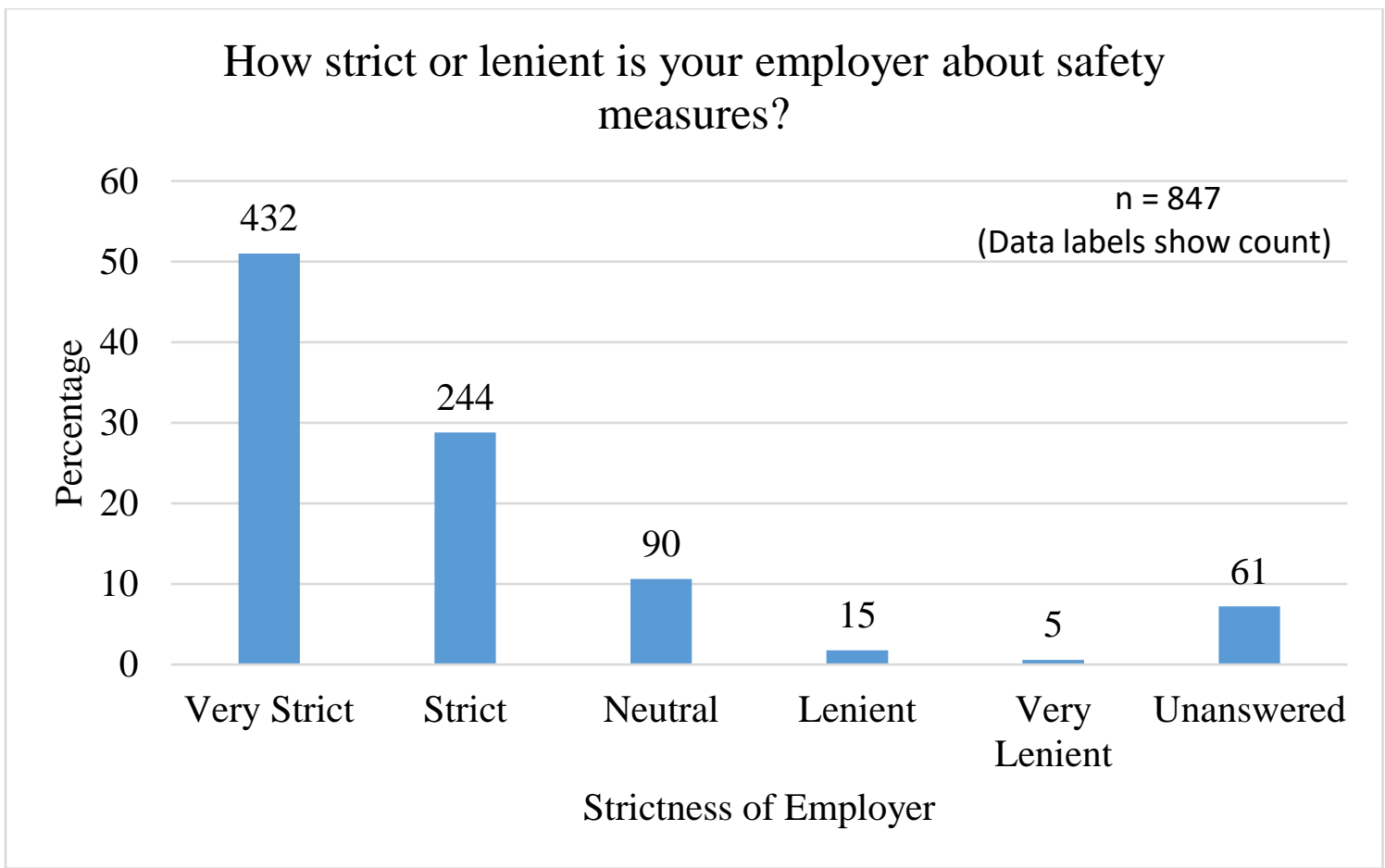

Figure 19: Employers' strictness about safety measures in Percentage

\subsubsection{Q10. "Do you get noticed for not following the safety procedures on site?"}

We place the 847 participants into the four categories: "Yes," "No," "Neutral," and "Unanswered," according to their response to this question. Nearly half of the participants said they were noticed if they did not follow safety procedures on site(Figure 20). An alarming 30\% responded that they were not noticed if they did not follow safety procedures on site. 


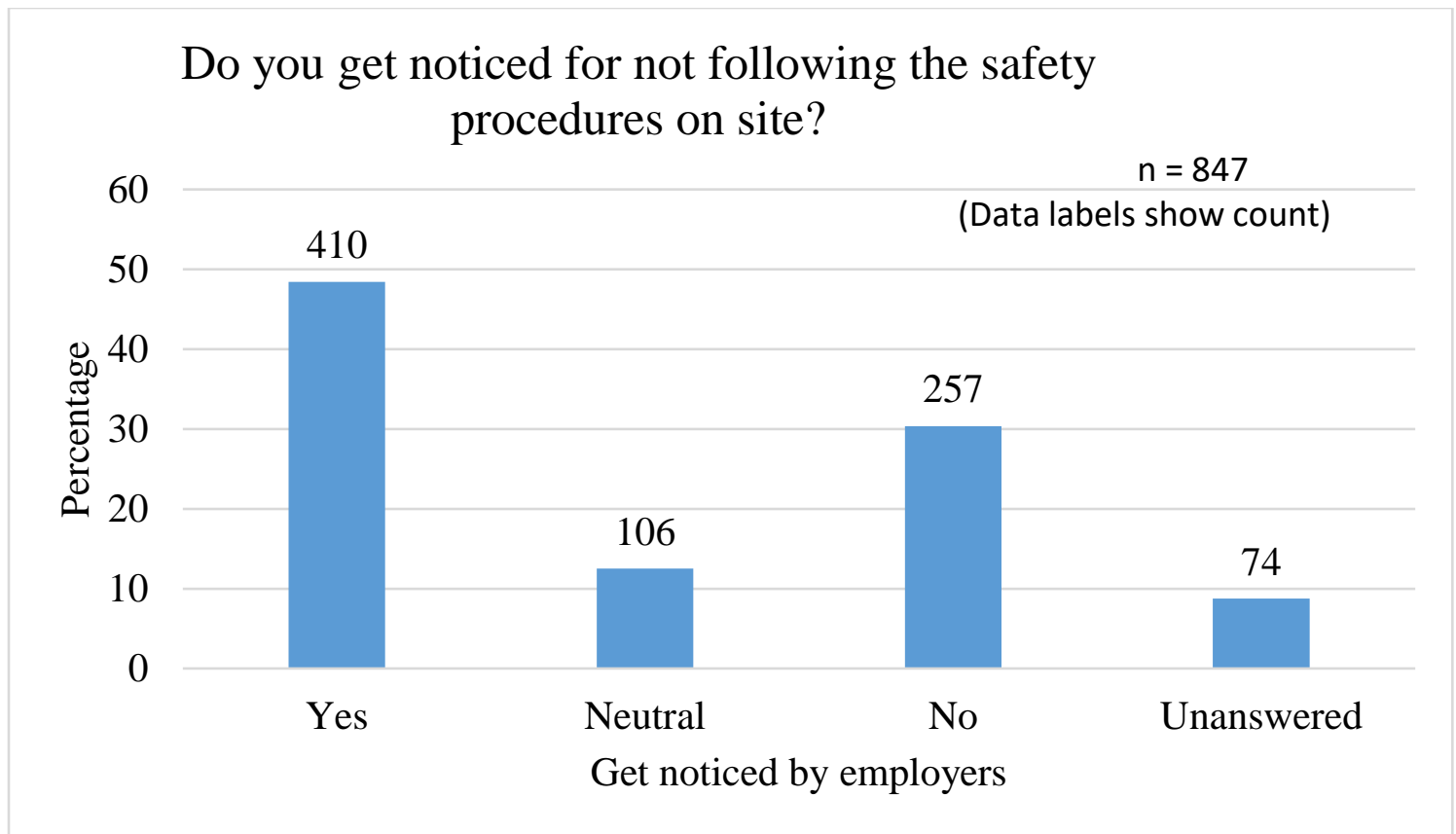

Figure 20: Percentage of participants who get noticed by employers if they don't follow safety procedures

\subsubsection{Q11. "Do you get rewarded for following the safety procedures on site?"}

We place the 847 participants into the four categories: "Yes," "No," "Neutral," and "Unanswered," according to their response to this question. More participants, about $41 \%$ said they were not rewarded compared to $25 \%$ of participants who said they were rewarded for following safety procedures on site(Figure 21). 


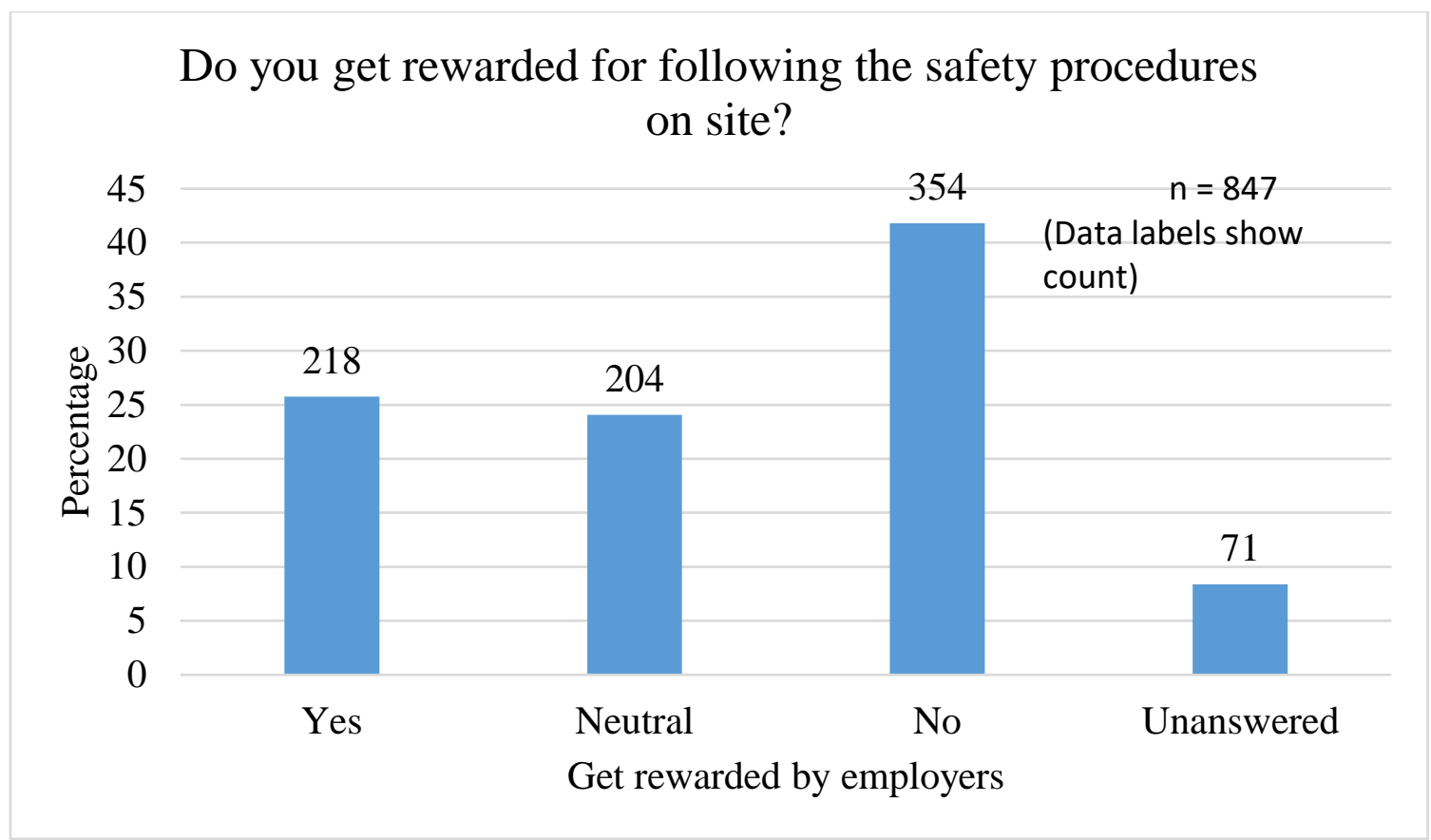

Figure 21: Percentage of participants who get rewarded by employers for following safety procedures

\subsubsection{Q12. "Would you be encouraged to follow the safety procedures if you were rewarded for doing so?"}

We place the 847 participants into the four categories: "Yes," "No," "Neutral," and "Unanswered," according to their response to this question. More than half, about 53\%, said they would be encouraged to follow safety procedures if rewarded(Figure 22). 


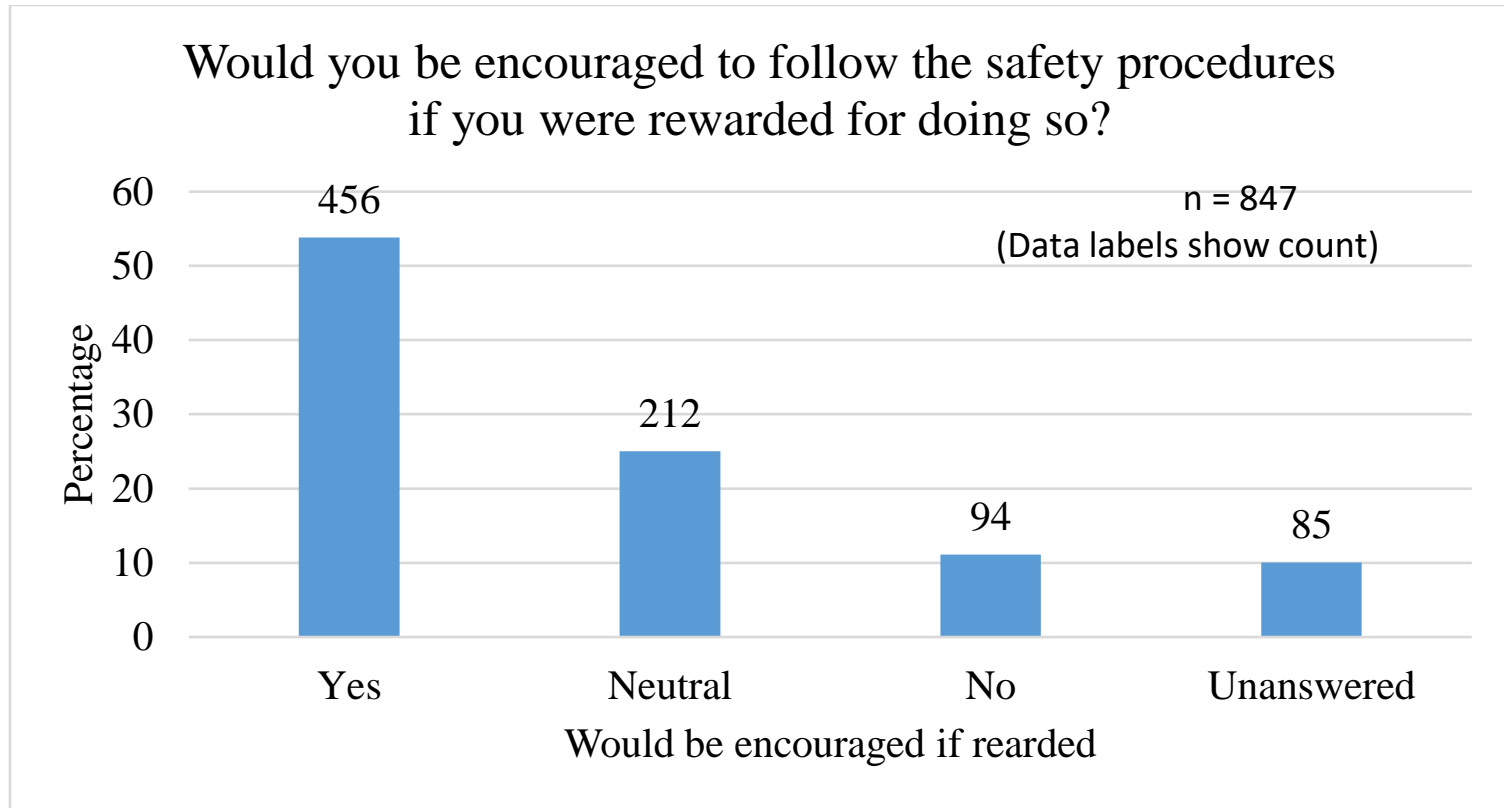

Figure 22: Percentage of participants who would be encouraged to follow the safety procedures if rewarded

\subsubsection{Q13. "Do you feel you have adequate knowledge about hazards and prevention measures?"}

We place the 847 participants into the four categories: "Yes," "No," "Neutral," and "Unanswered," according to their response to this question. About two-thirds of the participants said that they feel they have adequate knowledge about hazards and prevention measures(Figure 23). 


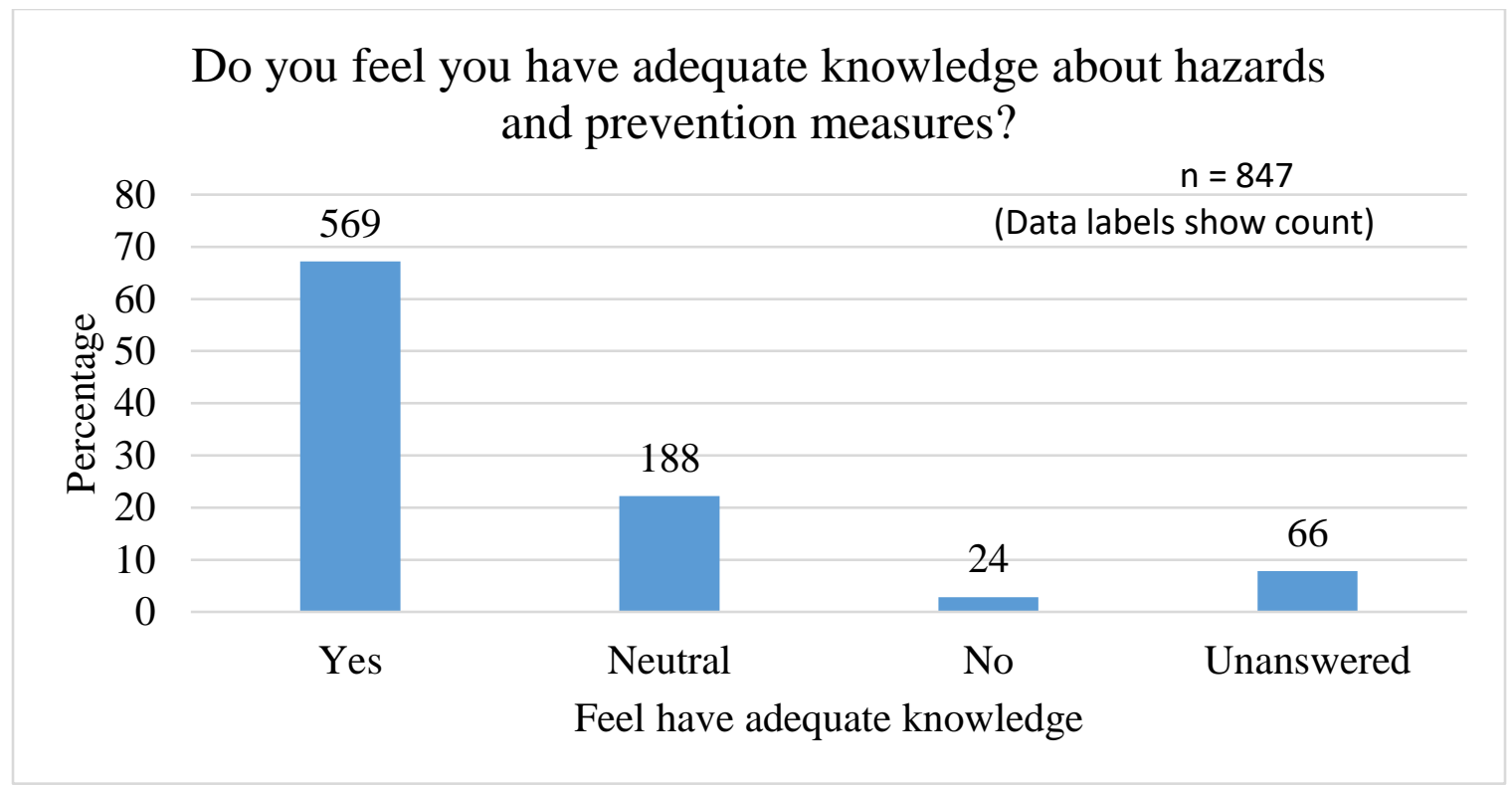

Figure 23: Participants who feel they have adequate safety knowledge in Percentage

\subsubsection{Q14. "How often do you encounter fall hazards on your job?"}

We place the 847 participants into the seven categories according to their response to this question. Participants who said they encountered fall hazards every day were $10 \%$ more than the other four categories ("Every week," "Every Month," "Every six months", and "Every Year") combined(Figure 24). 


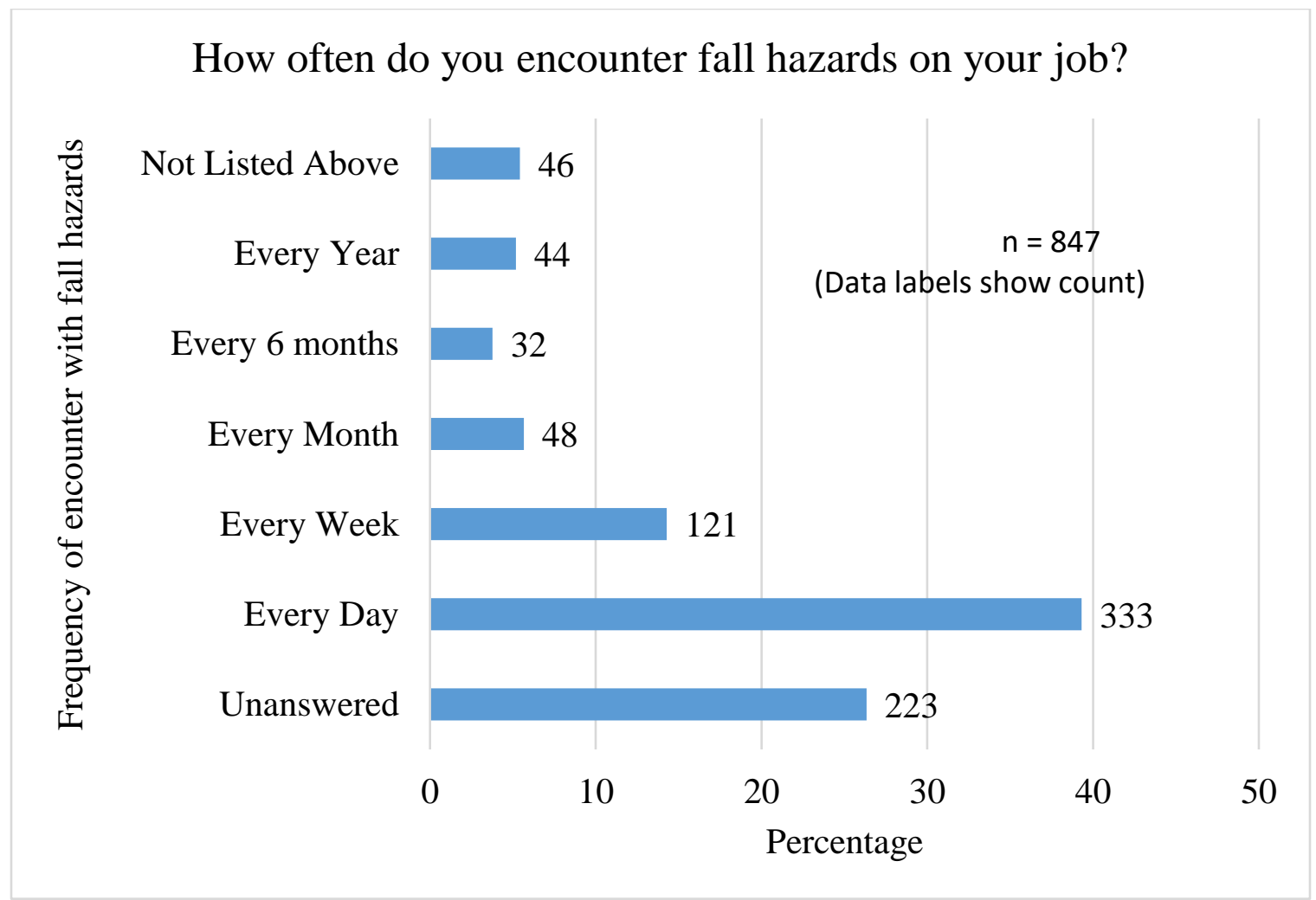

Figure 24: Participants' frequency of encounter with fall hazards in Percentage

\subsubsection{Q15. "Your work requires you to stand on an unprotected surface or edge in an upper level; you consider it safe if the lower level is"}

We place the 847 participants into the six categories according to their response to this question. About $27 \%$ of participants considered the lower level safe if it was at knee level(Figure 25). The other three categories ("Below your Head level," "Below your Waist level," "Below your Eye level") combined had only about $2 \%$ more responses than those who responded, "Below your Knee level." 


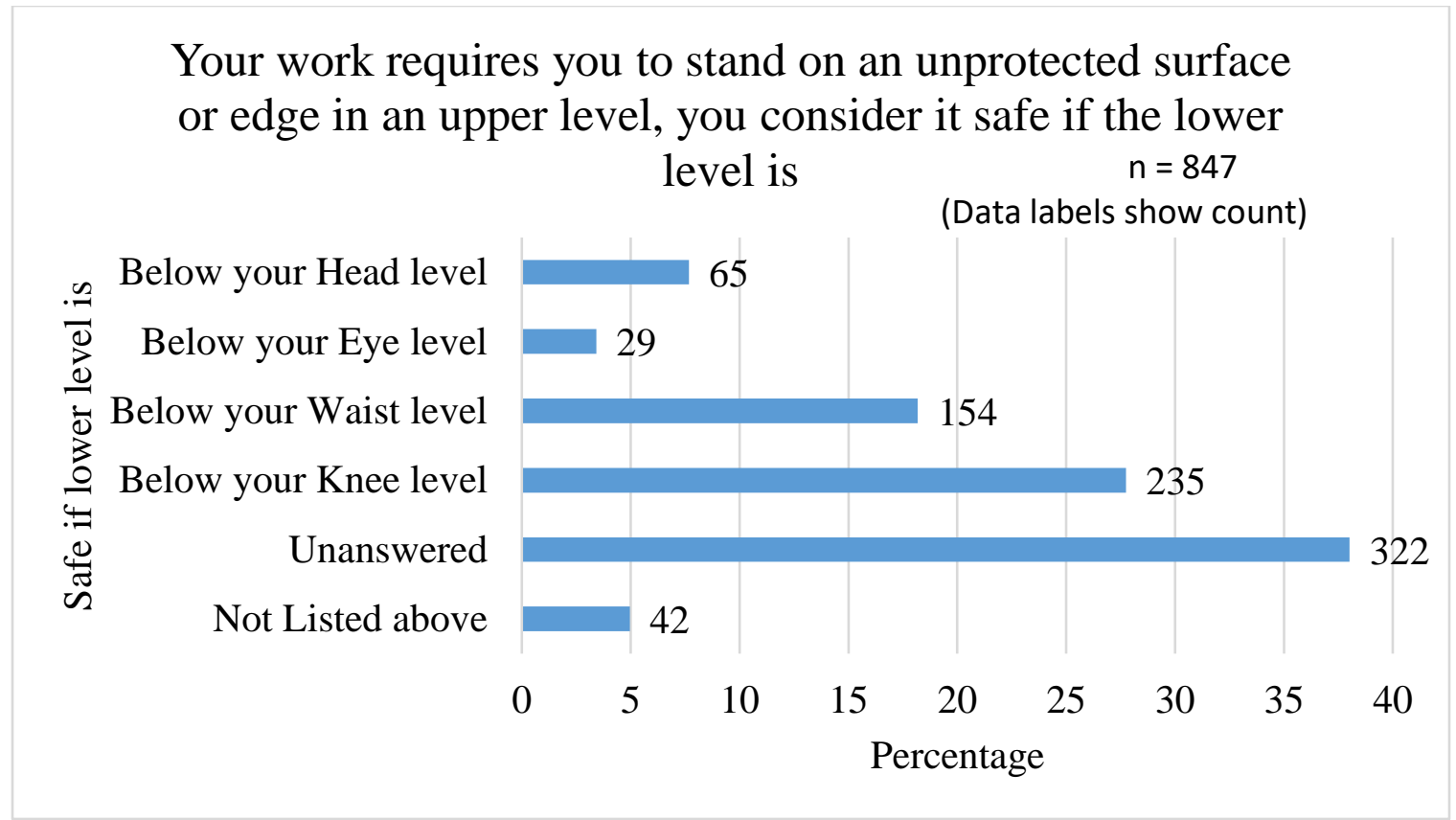

Figure 25: Considered safe lower level in Percentage

\subsubsection{Q16. "How often do you wear the following safety equipment while working on a construction site?"}

We place the 847 participants into the six categories according to their response to the question about wearing different safety equipment. More than half of the participants said they always wore hard hats, safety vests, safety goggles and safety gloves(Figure 26). Only 1 in 5 participants said they always used ear plugs and body harness. More participants said they never wore earplugs followed by a body harness than any other equipment. The discrepancy could be because body harness and earplugs are not common to every construction trade. 


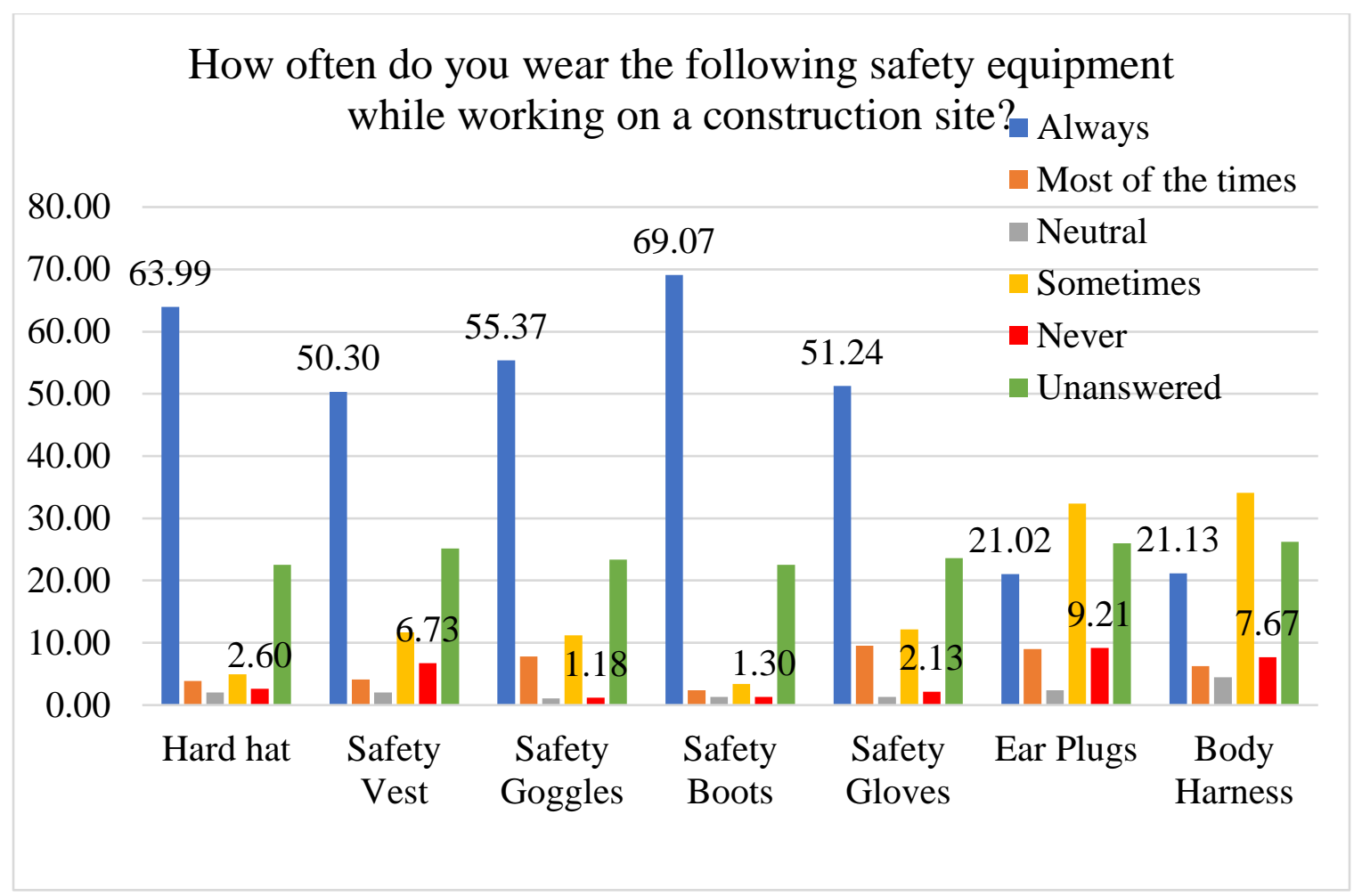

Figure 26: Safety Equipment Use in Percentage

\subsubsection{Q17. "Why do you NOT wear safety equipment? SELECT ALL THAT APPLY."}

We gave eight options to the participants to choose as reasons for not wearing safety equipment. The most common reason was "Reduces ability to work," followed by "Heat \& Sweat inducing," "Restricts movement," and "Ill-fitting"(Figure 27). The most common responses for people who chose not listed above and gave their own answer was "Not required for the job," followed by "Should always wear." 


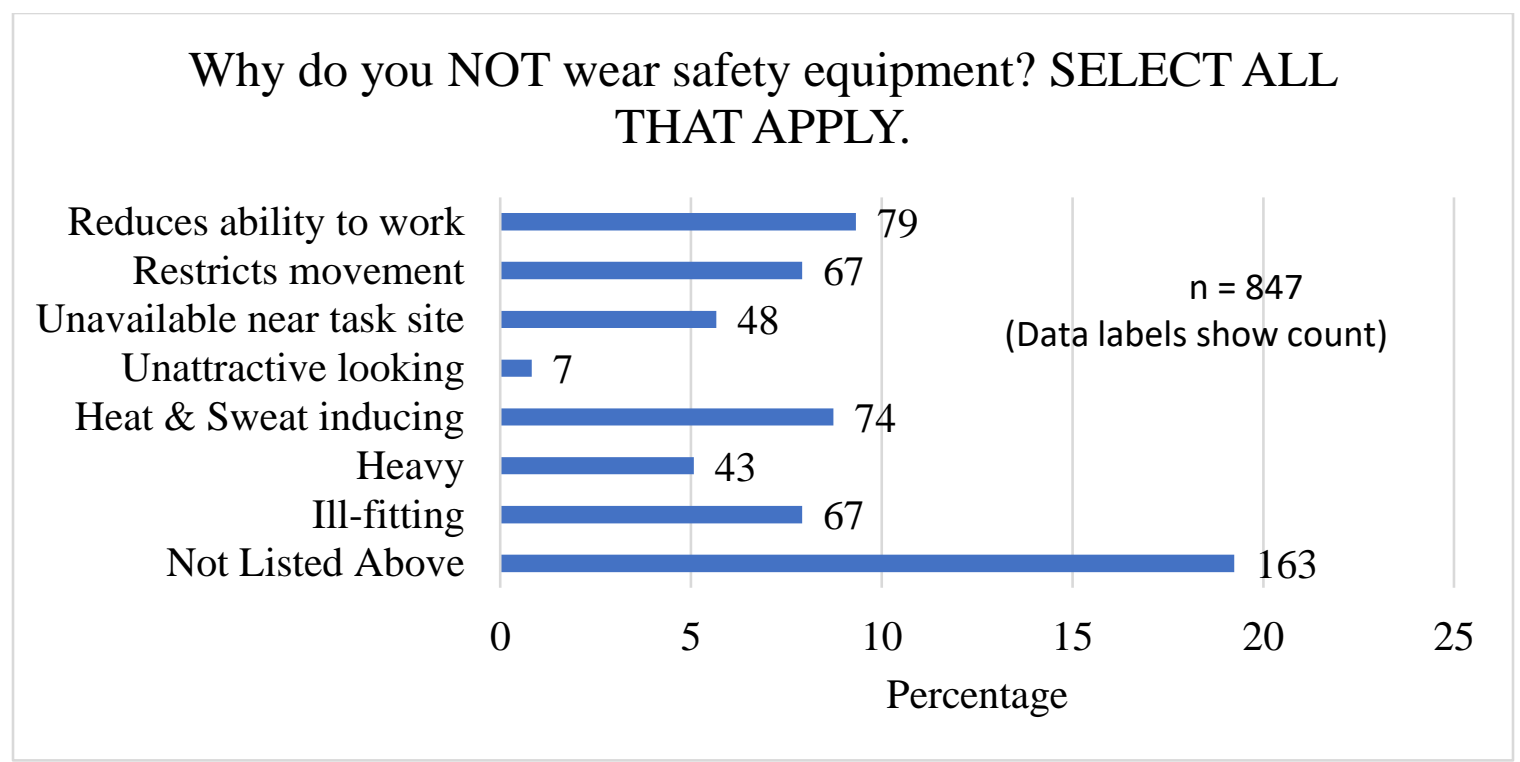

Figure 27: Reasons for not wearing safety equipment in Percentage

\subsubsection{Q18. "Do you think you should have a choice of NOT following} safety procedures?"

We place the 847 participants into the four categories: "Yes", "No", "Neutral", and "Unanswered", according to their response to this question. About two-thirds of the participants said that they should not have a choice of not following safety procedures(Figure 28). 


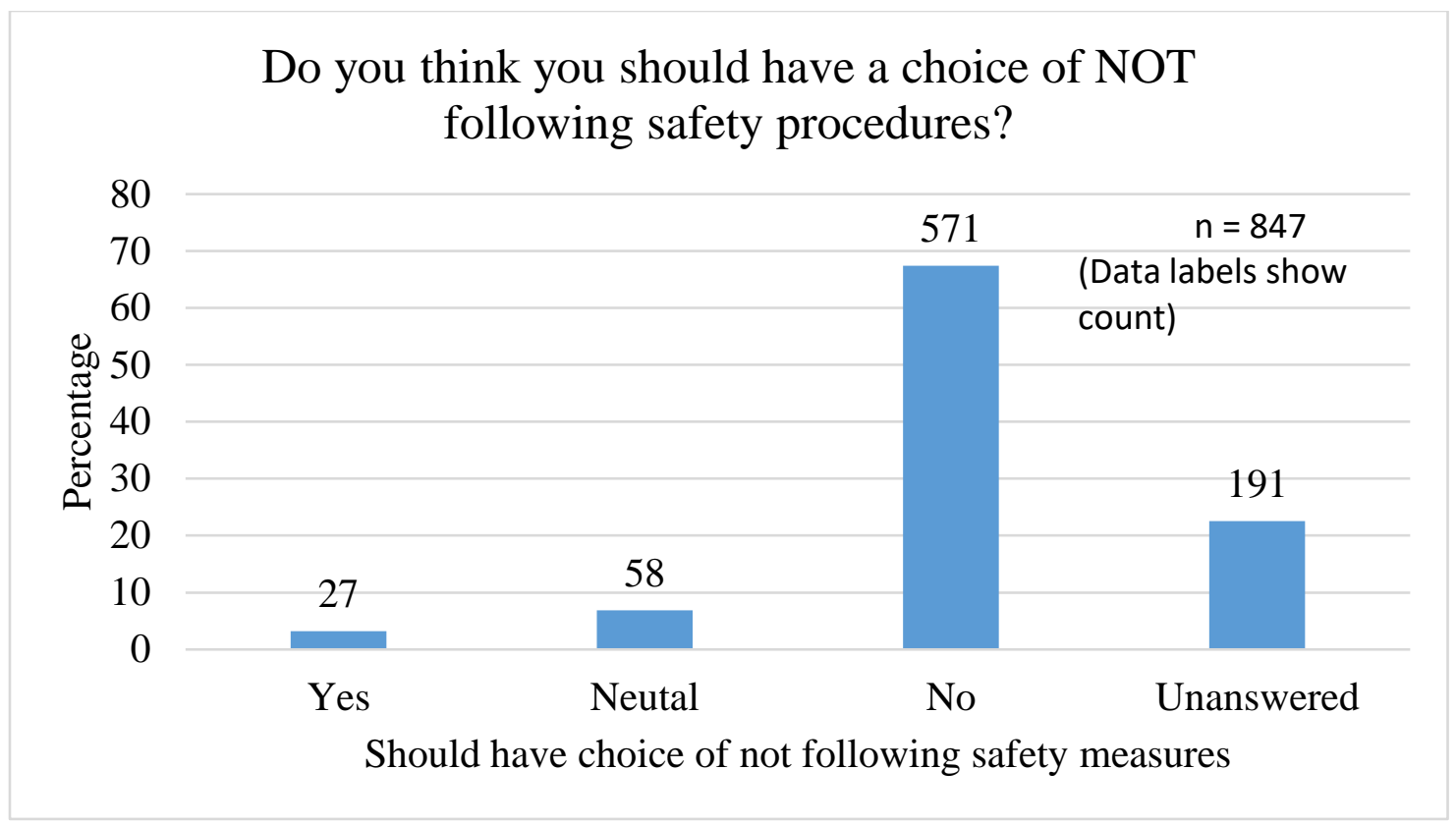

Figure 28: Should have a choice of not following safety measures in Percentage

\subsubsection{Q19. "Which of the following best explains your co-workers' safety habit?"}

We place the 847 participants into the six categories according to their response to the question. About twice as many participants said all their coworkers follow safety procedures compared to those who said most of their coworkers follow safety procedures(Figure 29). Participants who said that some of their coworkers follow safety procedures and none of their coworkers followed safety procedures added up to only $8 \%$ of the total participants. 


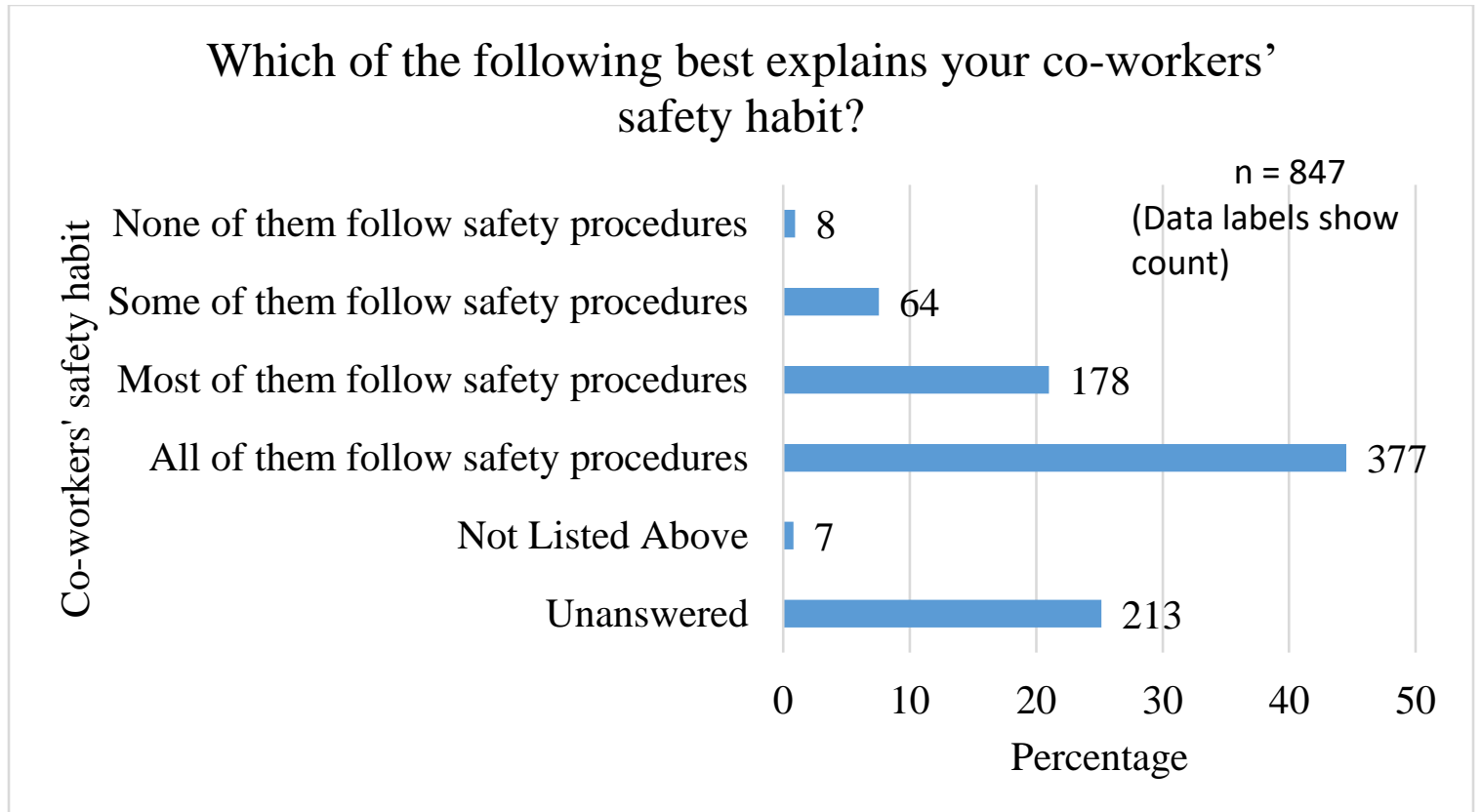

Figure 29: Coworkers follow safety measures in Percentage

\subsubsection{Q20. "Have you witnessed a co-worker having an accident due to fall hazards?"}

We place the 847 participants into the four categories: "Yes," "No," "Neutral," and "Unanswered," according to their response to this question. About three out of five participants said they had not witnessed a co-worker having an accident due to fall hazards(Figure 30). About one in ten participants said they had witnessed a co-worker having an accident due to fall hazards. 


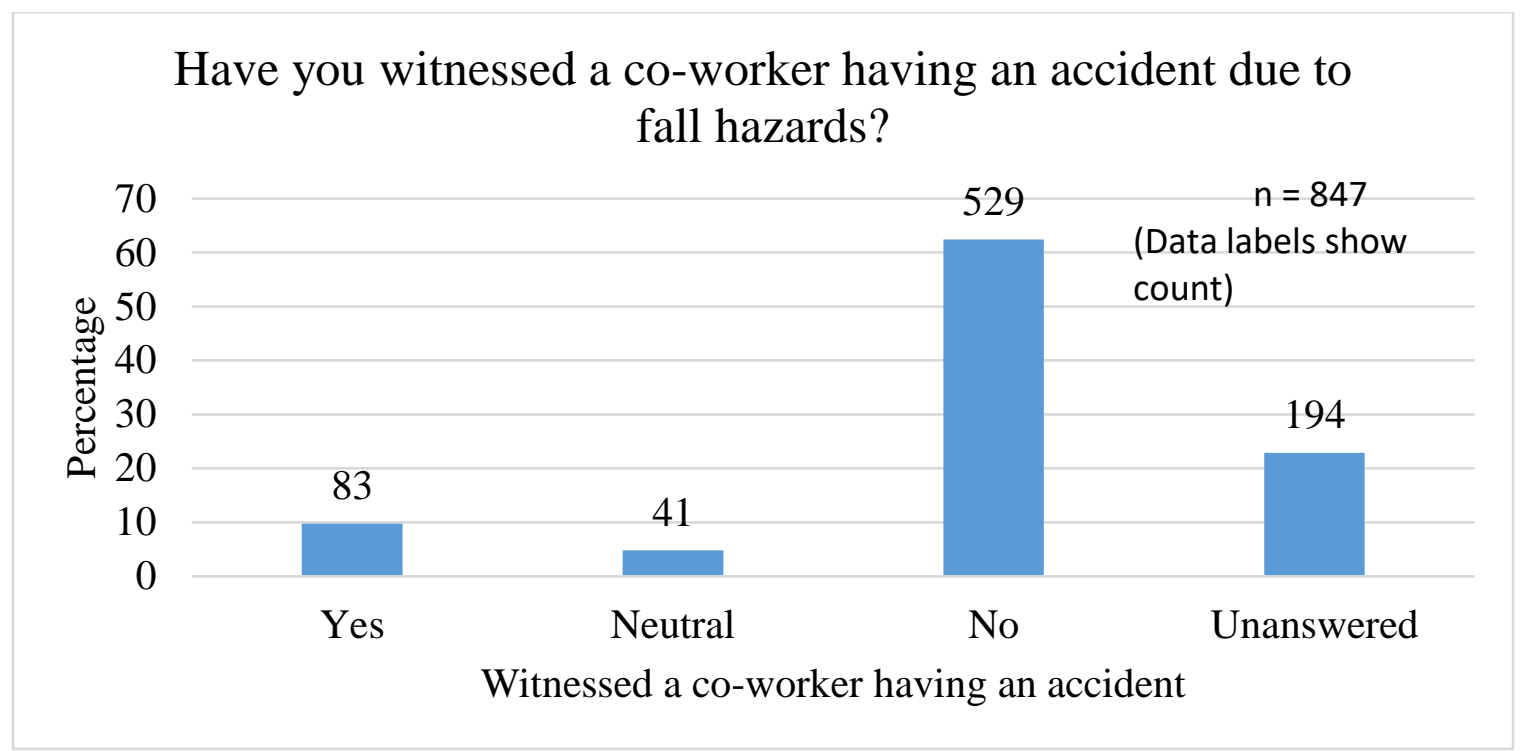

Figure 30: Have witnessed a co-worker having an accident due to fall hazards in Percentage

\subsubsection{Q21. 'How is your behavior affected by your co-workers' safety} behavior?"

We place the 847 participants into the four categories according to their response to this question. Nearly two-thirds of the participants said that they always follow the safety procedures irrespective of their co-workers(Figure 31). Participants in the other two categories who said they are in some form influenced by their coworkers' safety behavior added up to only about $8 \%$ of total participants. 
How is your behavior affected by your co-workers' safety behavior?

I will always follow the safety procedures irrespective of my co-...

I will follow what my co-workers do, unless I feel it is unsafe.

If my co-workers do not follow safety...』8

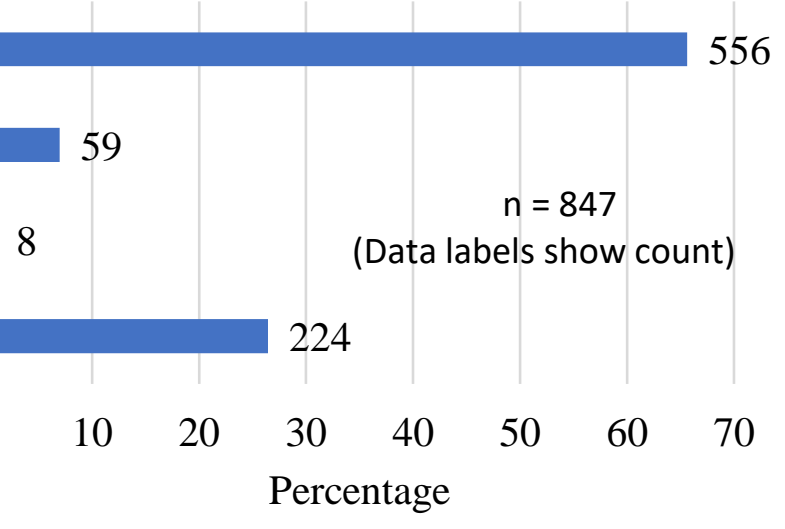

Figure 31: Effect of Co-workers' safety behavior in Percentage

\title{
3.3.1.22. Q22. "What would you do if you see your co-workers not
} following the safety procedures in a hazardous situation? SELECT

\begin{abstract}
ALL THAT APPLY."
We place the 847 participants into the four categories according to their response to this question. We added one more category for participants who had chosen two options given: "Ask them to follow safety procedures" and "Inform Safety Supervisor."

We observe that nearly two-thirds of the participants said they would ask their coworkers to follow safety procedures if they see them not doing so in a hazardous situation(Figure 32). Only a quarter of the participants said they would inform the safety supervisor. Only $15 \%$ of the total participants said they would use both options.
\end{abstract}




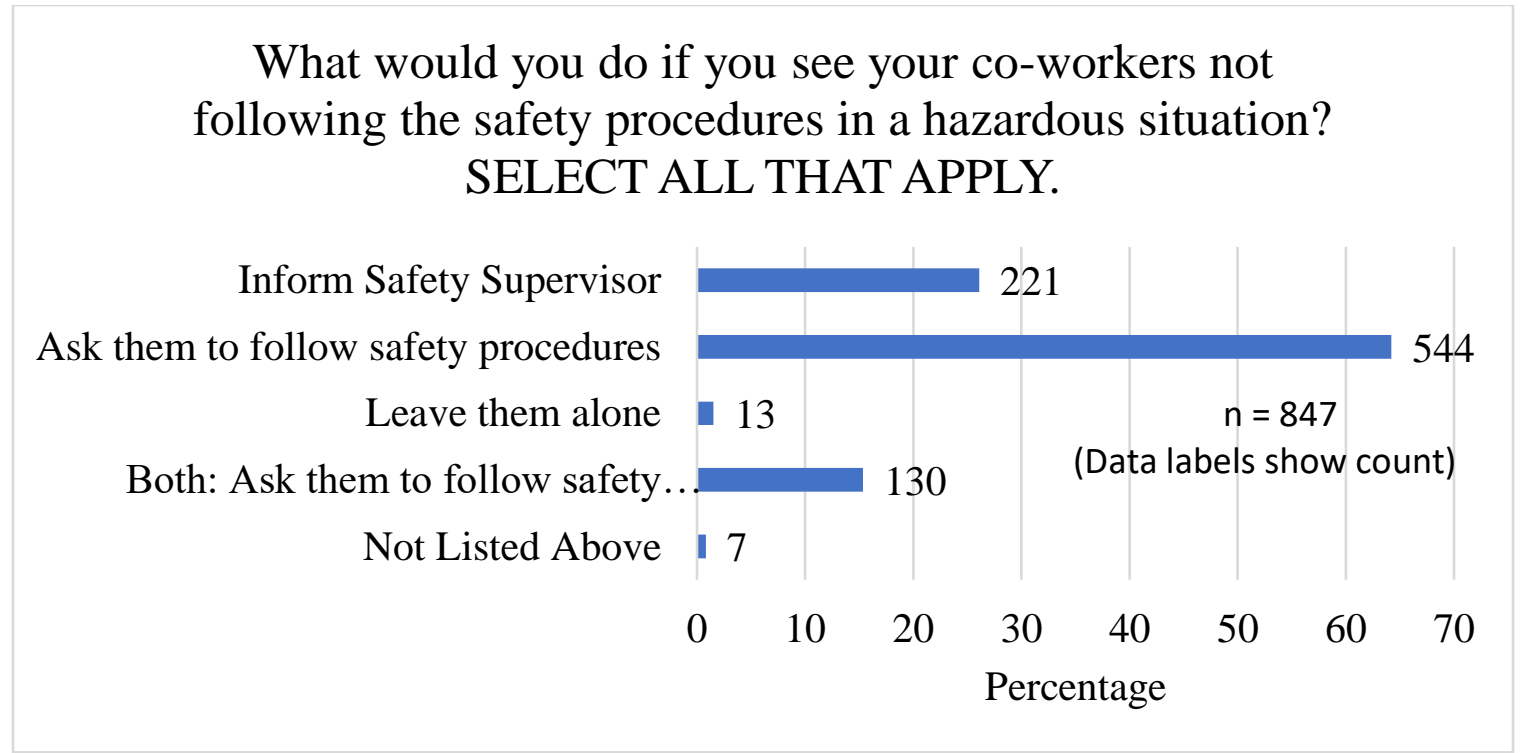

Figure 32: Action taken if you see coworkers not following the safety procedures in Percentage

\subsubsection{Combined Analysis}

\subsubsection{Possible Pairings}

For combined analysis, the responses of participants for two questions in the questionnaire, for example, "How old are you? ", and "What do you think about the adequacy of safety equipment provided by your employers?" were combined to see how response on one question related to the response on the second question.

\subsubsection{Logical Pairings}

However, not every pairing made logical sense. The attribute-related questions, asking age, education or experience of the participants, were not paired together as those pairings were not of interest in our study. Instead, attribute-related questions were paired with perspective-related questions, such as the age of the participant VS participants' opinion about their own safety knowledge were paired. Perspective-related questions, such as the 
provision of safety training on job site and effect of co-workers' safety behavior, which made logical sense were also paired together for analysis.

\subsubsection{Statistical Tests}

\subsection{Chi-square Test of Independence}

Chi-square test of independence is the most commonly used non-parametric hypothesis test for categorical (nominal or ordinal) data [32]. It is used to compare the relative frequency of two or more groups. Chi-square test is the comparison between the observed frequencies and expected frequencies of the data. The Chi-square statistic calculation is done by arranging the data into a contingency table. For example: if we compare two variables with two categories each, we would use a $2 \times 2$ contingency table. Following are the steps involved in the Chi-square test of independence:

Step1: Null and alternative hypothesis

The null hypothesis for the Chi-square test of Independence is that there is no relationship between the groups. The chi-square test statistic is denoted as " $\chi^{2 "}$. The null hypothesis is written as:

$\mathrm{H}_{0}: \chi^{2}=0$

The alternative hypothesis is that there is a relationship between the variables. Since the chi-square statistic always has a positive value, the alternative hypothesis states that chi-square statistic is greater than zero. The alternative hypothesis is written as:

$$
\mathrm{H}_{1}: \chi^{2}>0
$$




\section{Step 2: Chi-Square Distribution and Degree of freedom}

The probability distribution of the chi-square statistic is called chi-square distribution. The chi-square distribution is a family of curves whose shape are governed by the degree of freedom of the distribution. The degree of freedom depends on the size of the contingency table. It is calculated as:

The degree of freedom $=($ No. of rows in the table -1$) *($ No. of columns -1$)$

Step 3: Identify the critical value of the test statistic

The critical value of the test statistic depends on the degree of freedom and confidence level of the data. It is calculated from the Chi-square distribution table using the alpha value $(\alpha)$ and the degree of freedom (Df). It is denoted by " $\chi^{2}$ crit". For example, the degree of freedom for $2 \times 2$ contingency table is $1((2-1) *(2-1))$. At $95 \%(\alpha=0.05)$ confidence interval, the critical value of $\chi^{2}$ is 3.84 .

Step 4: Calculate the value of the test statistic $\left(\chi^{2}\right)$

The formula for calculating the Chi-square test statistic is:

$$
\chi^{2}=\sum \frac{(f o-f e)^{2}}{f e}
$$

Where,

$f_{0}=$ Observed frequency for each cell in the contingency table matrix.

$f_{e}=$ Expected frequency for each cell in the contingency table matrix. 
The expected frequency is calculated as:

$$
f_{e=\frac{(\text { Row Total }) *(\text { Column Total })}{\text { Sum of all frequencies }}}
$$

Step 5: Interpret the result

The decision on the hypothesis depends on whether the obtained chi-square statistic value exceeds the critical chi-square value or not. If $\chi 2>\chi 2$ crit then the null hypothesis is rejected. The alternative hypothesis becomes true which means there is a relationship between the test variables.

\subsection{Yates' Correction}

Yates' correction is used to calculate the chi-square statistic when the expected frequencies in any cell of the data matrix are less than five. The Yates' correction makes the standard for rejecting the null hypothesis more stringent. Yates' correction is applied by subtracting 0.5 from the absolute value of the difference between each observed and expected frequency in the table matrix. The formula for Yates' correction is:

$$
\chi 2=\sum \frac{(|f o-f e|-0.5)^{2}}{f e}
$$

We used the Chi-square Test of Independence with Yates' correction for the combined analysis portion of our which is discussed in the later section. We checked the independence of the variables in our data at $95 \%$ confidence level, or for an alpha value of 0.05 . 


\subsubsection{Significant Pairings}

Not every logical pairing yielded statistically significant results, though. Only those logical pairings which had statistical significance at the set confidence interval are presented in Table 5 below.

Table 5: Table Showing Logical Pairings Made

\begin{tabular}{|c|c|c|c|c|c|c|c|c|c|c|c|c|c|c|c|c|c|c|c|c|c|c|}
\hline Form-2 & Q1 & Q2 & Q3 & Q4 & Q5 & Q6 & Q7 & Q8 & Q9 & Q10 & Q11 & Q12 & Q13 & Q14 & Q15 & Q16 & Q17 & Q18 & Q19 & Q20 & Q21 & Q22 \\
\hline \multicolumn{23}{|l|}{ Q1 } \\
\hline \multicolumn{23}{|l|}{ Q2 } \\
\hline Q3 & & & & & & & & & & & & & \multicolumn{3}{|c|}{$p$-value $>0.10$} & & & & & & & \\
\hline Q4 & & & & & & & & & & & & & \multicolumn{3}{|c|}{$p$-value $<0.10$} & & & & & & & \\
\hline Q5 & 0.0047 & 0.373 & 0.295 & 0.981 & & & & & & & & & \multicolumn{5}{|c|}{$\mathrm{p}$-value $<0.10$ but no trend } & & & & & \\
\hline Q6 & 0.261 & 0.092 & 0.641 & 0.908 & & & & & & & & & & & & & & & & & & \\
\hline \multicolumn{23}{|l|}{ Q7 } \\
\hline Q8 & 0.889 & 0.691 & 0.001 & 0.882 & & & & & & & & & & & & & & & & & & \\
\hline Q9 & 0.883 & 0.955 & 0.295 & 0.241 & & & & & & & & & & & & & & & & & & \\
\hline Q10 & 0.066 & 0.013 & 0.0001 & 0.0001 & & & & & & & & & & & & & & & & & & \\
\hline Q11 & 0.122 & 0.597 & 0.017 & 0.0978 & & & & & & & & & & & & & & & & & & \\
\hline Q12 & 0.836 & 0.189 & 0.29 & 0.252 & & & & & & & & & & & & & & & & & & \\
\hline Q13 & 0.794 & 0.002 & 0.154 & 0.025 & & 0.000 & & & & & & 0.0001 & & & & & & & & & & \\
\hline Q14 & 0.918 & 0.661 & 0.757 & 0.928 & & \begin{tabular}{|l|l|} 
\\
\end{tabular} & & & 0.716 & & & & 0.54 & & & & & & & & & \\
\hline Q15 & 0.85 & 0.297 & 0.918 & 0.805 & & & & & & & & & & & & & & & & & & \\
\hline \multicolumn{23}{|l|}{ Q16 } \\
\hline \multicolumn{23}{|l|}{ Q17 } \\
\hline Q18 & 0.654 & 0.904 & 0.361 & 0.615 & & & & & & & & & & & & & & & & & & \\
\hline Q19 & 0.563 & 0.453 & 0.256 & 0.976 & 0.1214 & 0.000 & & & 0.000 & 0.0001 & & 0.0001 & & \begin{tabular}{|l|}
0.894 \\
\end{tabular} & & & & & & & & \\
\hline Q20 & 0.153 & 0.0004 & 0.105 & 0.799 & & 0.067 & & & 0.002 & & & & & & & & & & 0.0829 & & & \\
\hline Q21 & 0.421 & \begin{tabular}{|l|}
0.349 \\
\end{tabular} & 0.013 & 0.255 & 0.542 & 0.001 & & & 0.0001 & & & 0.789 & 0.281 & & & & & & & 0.0080 & & \\
\hline Q22 & & & & & & & & & & & & & & & & & & & & & & \\
\hline
\end{tabular}

\subsection{Experience of the participants' vs Adequacy of the} knowledge about hazards and prevention measures

We analyzed the participants' response to two of the questions asked in the questionnaire: "How many years of experience do you have in the construction industry?" and "Do you feel you have adequate knowledge about hazards and prevention measures?". The first question inquiring about the years of experience of the participants allowed participants to choose one of these six categories: "Zero," "0-2", "3-5", "6-10", "11-20", and "More than 20". The second question allowed participants to choose one of the three 
categories: "Yes," "Neutral," and "No." Table 6 below shows the observed frequency of the responses to those two questions.

Table 6: Observed Frequency Table for Q2 vs Q13

\begin{tabular}{|l|l|c|c|c|c|c|c|c|c|c|}
\hline & \multicolumn{7}{|l|}{ Observed Frequency Table } \\
\hline & Q2 & \multicolumn{7}{|l|}{ How many years of experience do you have in the construction industry? } \\
\hline & & & Zero & $\mathbf{0 - 2}$ & $\mathbf{3 - 5}$ & $\mathbf{1 0 - 1 9}$ & $\mathbf{1 1 - 2 0}$ & More than 20 & Unanswered \\
\hline $\begin{array}{l}\text { Q1 } \\
\mathbf{3}\end{array}$ & Do you feel you have adequate knowledge about hazards and prevention measures? \\
\hline & Yes & 29 & 167 & 125 & 78 & 81 & 68 & 21 \\
\hline & Neutral & 28 & 59 & 40 & 20 & 24 & 9 & 8 \\
\hline & No & 5 & 8 & 3 & 4 & 3 & 1 & 0 \\
\hline & $\begin{array}{l}\text { Unanswere } \\
\text { d }\end{array}$ & 8 & 17 & 11 & 7 & 10 & 7 & 6 \\
\hline
\end{tabular}

Table 7 below shows the expected frequency calculated for the data. Data from the "Unanswered" category was not used in the analysis. The expected frequency is calculated as:

$$
f_{e}=\frac{(\text { Row Total }) *(\text { Column Total })}{\text { Sum of all frequencies }}
$$


Table 7: Expected Frequency Table for Q2 vs Q13

\begin{tabular}{|c|c|c|c|c|c|c|c|}
\hline & \multicolumn{7}{|c|}{ Expected Frequency Table } \\
\hline & Q2 & \multicolumn{6}{|c|}{ How many years of experience do you have in the construction industry? } \\
\hline & & Zero & $0-2$ & $3-5$ & 10-19 & 11-20 & More than 20 \\
\hline Q1 & \multicolumn{7}{|c|}{$\begin{array}{l}\text { Do you feel you have adequate knowledge about hazards and prevention } \\
\text { measures? }\end{array}$} \\
\hline \multicolumn{2}{|c|}{ Yes } & 45.181 & 170.521 & 122.426 & 74.330 & 78.702 & 56.840 \\
\hline \multicolumn{2}{|c|}{ Neutral } & 14.840 & 56.011 & 40.213 & 24.415 & 25.851 & 18.670 \\
\hline \multicolumn{2}{|c|}{ No } & 1.979 & 7.468 & 5.362 & 3.255 & 3.447 & 2.489 \\
\hline
\end{tabular}

Table 8 below shows the Yates' Correction for the Chi-Square Test of Independence. The formula for Yates' correction is:

$$
\chi 2=\sum \frac{(|f o-f e|-0.5)^{2}}{f e}
$$

Table 8: Yates' Correction Calculation Table for Q2 vs Q13

\begin{tabular}{|c|c|c|c|c|c|c|c|}
\hline & & \multicolumn{6}{|c|}{ Yates' Correction Calculation Table } \\
\hline & Q2 & \multicolumn{6}{|c|}{ How many years of experience do you have in the construction industry? } \\
\hline & & Zero & 0-2 & 3-5 & 10-19 & 11-20 & More than 20 \\
\hline Q13 & & \multicolumn{6}{|c|}{$\begin{array}{l}\text { Do you feel you have adequate knowledge about hazards and prevention } \\
\text { measures? }\end{array}$} \\
\hline Ye & & 5.442 & 0.054 & 0.035 & 0.135 & 0.041 & 1.999 \\
\hline Neu1 & ral & 10.799 & 0.111 & 0.002 & 0.628 & 0.071 & 4.504 \\
\hline $\mathbf{N}$ & & 3.213 & 0.000 & 0.646 & 0.018 & 0.001 & 0.393 \\
\hline \multicolumn{4}{|c|}{ Chi-Square Statistic Sum } & 28.0923 & & & \\
\hline \multicolumn{4}{|c|}{ Degree of Freedom } & 10.0000 & & & \\
\hline \multicolumn{4}{|c|}{ P-value calculated } & 0.0017 & & & \\
\hline \multirow{2}{*}{\multicolumn{4}{|c|}{$\begin{array}{l}\text { Significance Level } \\
\text { The result is significant at } p< \\
0.05\end{array}$}} & 0.0500 & & & \\
\hline & & & & & & & \\
\hline
\end{tabular}

The chi-square test shows that the variables are independent, and the result is significant at $95 \%$ confidence interval. 
We wanted to evaluate how participants with different levels of experience report their knowledge about hazards and prevention. The responses of the participants are represented by the "100\% stacked" chart (Figure 33).

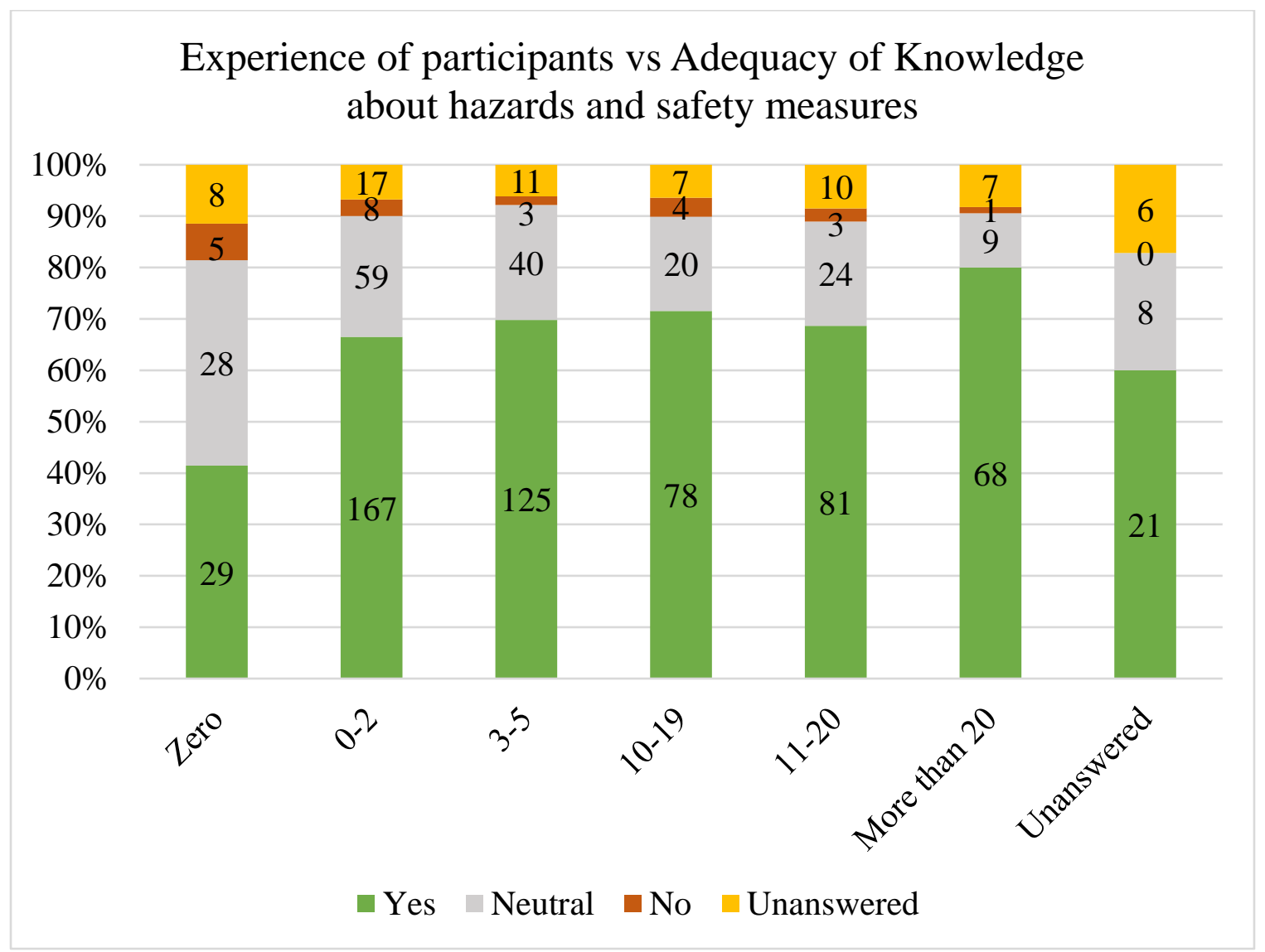

Figure 33: Experience of participants vs Adequacy of Knowledge about hazards and safety measures

We observed that participants with more experience tend to answer "Yes" to the question about the adequacy of their knowledge about fall hazards and prevention measures. Only about $41 \%$ of the participants reported that they feel they have adequate knowledge about hazards and prevention measures. The frequency of participants who felt they had adequate knowledge about hazards and prevention measures increased to about 
$67 \%$ for participants with $0-2$ years of experience. The frequency showed a gradual increase of about $70 \%$ and $72 \%$ over the next two categories. While the frequency slightly decreased from $72 \%$ for participants with 10-19 years of experience to $69 \%$ for participants with 11-19 years of experience, the frequency was highest at $80 \%$ for participants with more than 20 years of experience.

\subsection{Age of the participant vs. effect of co-workers' safety behavior on the participants.}

We analyzed the participants' response to two of the questions asked in the questionnaire: "How old are you? ", and "How is your behavior affected by your coworkers' safety behavior?". The first question inquiring about the age of the participants allowed participants to choose one of these six categories: "Less than 18", "18-29", "3049", "50-65", and "More than 65". The second question allowed participants to choose one of the three categories: "If my co-workers do not follow safety procedures, I don't too", "I will follow what my co-workers do, unless I feel it is unsafe", and "I will always follow the safety procedures irrespective of my co-workers". Table 9 below shows the observed frequency of the responses to those two questions. 
Table 9: Observed Frequency Table for Q3 vs Q21

\begin{tabular}{|c|c|c|c|c|c|c|c|}
\hline & \multicolumn{7}{|c|}{ Observed Frequency Table } \\
\hline & Q3 & \multicolumn{6}{|c|}{ How old are you? } \\
\hline & & $\begin{array}{l}\text { Less than } \\
18\end{array}$ & $18-29$ & $30-49$ & $50-65$ & $\begin{array}{l}\text { More } \\
\text { than } 65\end{array}$ & Unanswered \\
\hline Q21 & \multicolumn{7}{|c|}{ How is your behavior affected by your co-workers' safety behavior? } \\
\hline & $\begin{array}{l}\text { If my co-workers } \\
\text { do not follow } \\
\text { safety procedures, } \\
\text { I don't too. }\end{array}$ & 0 & 3 & 4 & 1 & 0 & 0 \\
\hline & $\begin{array}{l}\text { I will follow what } \\
\text { my co-workers do, } \\
\text { unless I feel it is } \\
\text { unsafe. }\end{array}$ & 0 & 31 & 22 & 4 & 1 & 1 \\
\hline & $\begin{array}{l}\text { I will always } \\
\text { follow the safety } \\
\text { procedures } \\
\text { irrespective of my } \\
\text { co-workers. }\end{array}$ & 0 & 161 & 271 & 101 & 4 & 19 \\
\hline & Unanswered & 1 & 58 & 105 & 42 & 11 & 7 \\
\hline
\end{tabular}

Table 10 below shows the expected frequency calculated for the data. Data from "Less than 18 " category which had only one participant and "Unanswered" category was not used in the analysis.

Table 10: Expected Frequency for Q3 vs. Q21

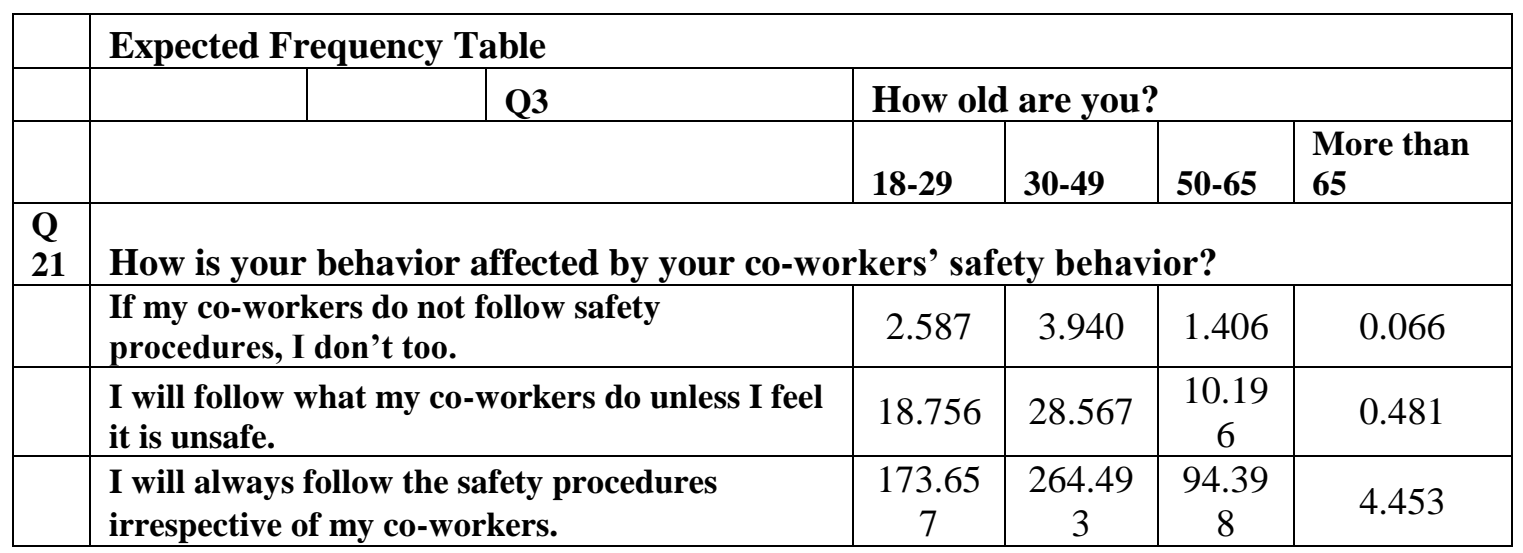


Table 11 below shows the Yates' Correction for the Chi-Square Test of Independence.

Table 11: Yates Correction Calculation Table for Q3 vs Q21

\begin{tabular}{|c|c|c|c|c|c|}
\hline & \multicolumn{5}{|c|}{ Yates Correction Calculation Table } \\
\hline & Q3 & \multicolumn{4}{|c|}{ How old are you? } \\
\hline & & $18-29$ & $30-49$ & $50-65$ & More than 65 \\
\hline Q21 & \multicolumn{5}{|c|}{ How is your behavior affected by your co-workers' safety behavior? } \\
\hline \multicolumn{2}{|c|}{$\begin{array}{l}\text { If my co-workers do not follow safety } \\
\text { procedures, I don't too. }\end{array}$} & 0.003 & 0.049 & 0.006 & 2.835 \\
\hline \multicolumn{2}{|c|}{$\begin{array}{l}\text { I will follow what my co-workers do unless I feel } \\
\text { it is unsafe. }\end{array}$} & 7.353 & 1.289 & 3.182 & 0.001 \\
\hline \multicolumn{2}{|c|}{$\begin{array}{l}\text { I will always follow the safety procedures } \\
\text { irrespective of my co-workers. }\end{array}$} & 0.851 & 0.136 & 0.394 & 0.001 \\
\hline \multicolumn{2}{|c|}{ Chi-Square Statistic Sum } & 16.10011 & & & \\
\hline \multicolumn{2}{|l|}{ Degree of Freedom } & 6 & & & \\
\hline \multicolumn{2}{|l|}{ P-value calculated } & 0.0132 & & & \\
\hline \multicolumn{2}{|l|}{ Significance Level } & 0.0500 & & & \\
\hline \multicolumn{2}{|c|}{ The result is significant at $p<0.05$} & & & & \\
\hline
\end{tabular}

The chi-square test shows that the variables are independent, and the result is significant at $95 \%$ confidence interval.

We wanted to evaluate how participants of different age groups report their knowledge about hazards and prevention. The responses of the participants are represented by the "100\% stacked" chart below(Figure 34): 


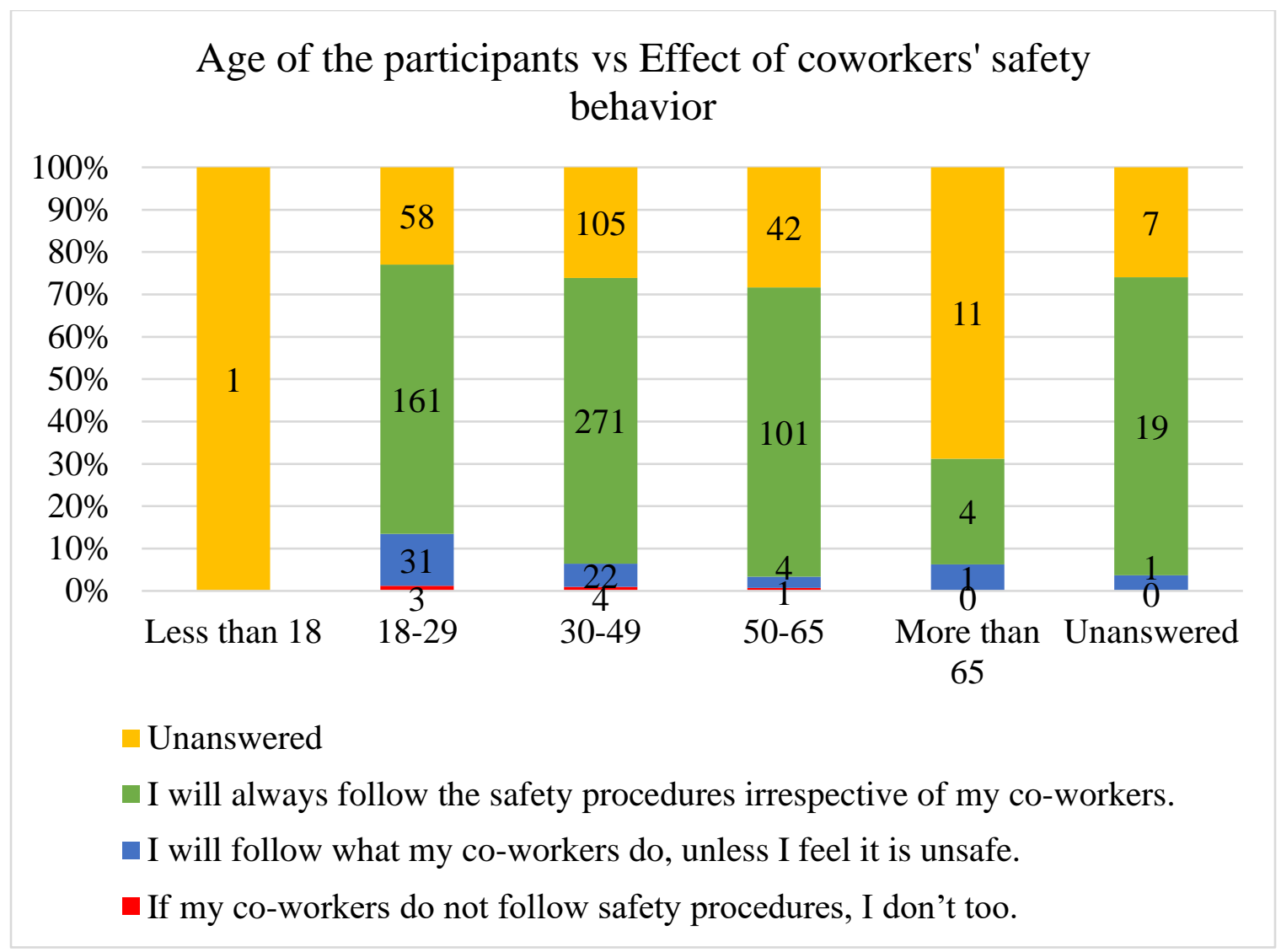

Figure 34: Age of the participants vs. Effect of coworkers' safety behavior

We observed that younger participants tend to follow their co-workers more compared to older participants. The age group of "Less than 18 " had only one participant who did not respond to the second question. Hence, this group is not included in the analysis done in this section. Participants of "18-29" age group had the highest percentage of participants who answered that they would not follow safety procedures if their co-workers did not. The frequency of that response decreased as the age of the participants increased, from about $1.2 \%$ for age-group " $18-29$ " to about $1 \%$ for age-group " $30-49$ " and about $0.7 \%$ for age-group "50-65". A similar trend was observed for the three age-groups when participants said that they would follow their co-workers unless they felt it was unsafe. The 
frequency of that response decreased as the age of the participants increased, from about $12 \%$ for age-group " $18-29$ " to about $5 \%$ for age-group " $30-49$ " and about $3 \%$ for age-group “50-65".

We also observed that a higher percentage of the older participants tend to respond that they will always follow safety procedures irrespective of their co-workers. The frequency of that response was highest, about $68 \%$ for age group " $50-65$ ". The frequency of that response decreased as the age of the participants decreased: about $67 \%$ for age-group "3049 " to about $63 \%$ for age-group 18-29. We also observed that the age group "More than 65 " did not follow the trend of the other three groups. This discrepancy might have happened because of a low number of participants in that particular age-group.

\subsection{Age of the participant vs. adequacy of the safety equipment provided by their employers}

We analyzed the participants' response to two of the questions asked in the questionnaire: "How old are you? ", and "What do you think about the adequacy of safety equipment provided by your employers?". The first question inquiring about the age of the participants allowed participants to choose one of these six categories: "Less than 18", "1829", "30-49", "50-65", and "More than 65". The second question allowed participants to choose one of the five categories: "All the workers are provided safety equipment", "Most of the workers are provided safety equipment", "Only a few of the workers are provided safety equipment", "None of the workers are provided safety equipment", and "Not Listed Above". Table 12 below shows the observed frequency of the responses to those two questions. 
Table 12: Observed Frequency Table for Q3 vs Q8

\begin{tabular}{|c|c|c|c|c|c|c|c|}
\hline & \multicolumn{7}{|c|}{ Observed Frequency Table } \\
\hline & Q3 & \multicolumn{6}{|c|}{ How old are you? } \\
\hline & & Less than 18 & 18-29 & 30-49 & $50-65$ & More than 65 & Unanswered \\
\hline Q8 & \multicolumn{7}{|c|}{$\begin{array}{l}\text { What do you think about the adequacy of safety equipment provided by your } \\
\text { employers? }\end{array}$} \\
\hline & $\begin{array}{l}\text { All the workers } \\
\text { are provided } \\
\text { safety } \\
\text { equipment }\end{array}$ & 1 & 198 & 307 & 100 & 7 & 17 \\
\hline & $\begin{array}{l}\text { Most of the } \\
\text { workers are } \\
\text { provided safety } \\
\text { equipment }\end{array}$ & 0 & 17 & 34 & 9 & 2 & 1 \\
\hline & $\begin{array}{l}\text { Only few of the } \\
\text { workers are } \\
\text { provided safety } \\
\text { equipment }\end{array}$ & 0 & 11 & 10 & 14 & 1 & 1 \\
\hline & $\begin{array}{l}\text { None of the } \\
\text { workers are } \\
\text { provided safety } \\
\text { equipment }\end{array}$ & 0 & 4 & 11 & 4 & 0 & 0 \\
\hline & $\begin{array}{l}\text { Not Listed } \\
\text { Above }\end{array}$ & 0 & 2 & 2 & 8 & 2 & 0 \\
\hline & Unanswered & 0 & 21 & 38 & 13 & 4 & 8 \\
\hline
\end{tabular}

Table 13 below shows the expected frequency calculated for the data. Data from "Less than 18 " category which had only one participant and "Unanswered" category was not used in the analysis. 
Table 13: Expected Frequency Table for Q3 vs Q8

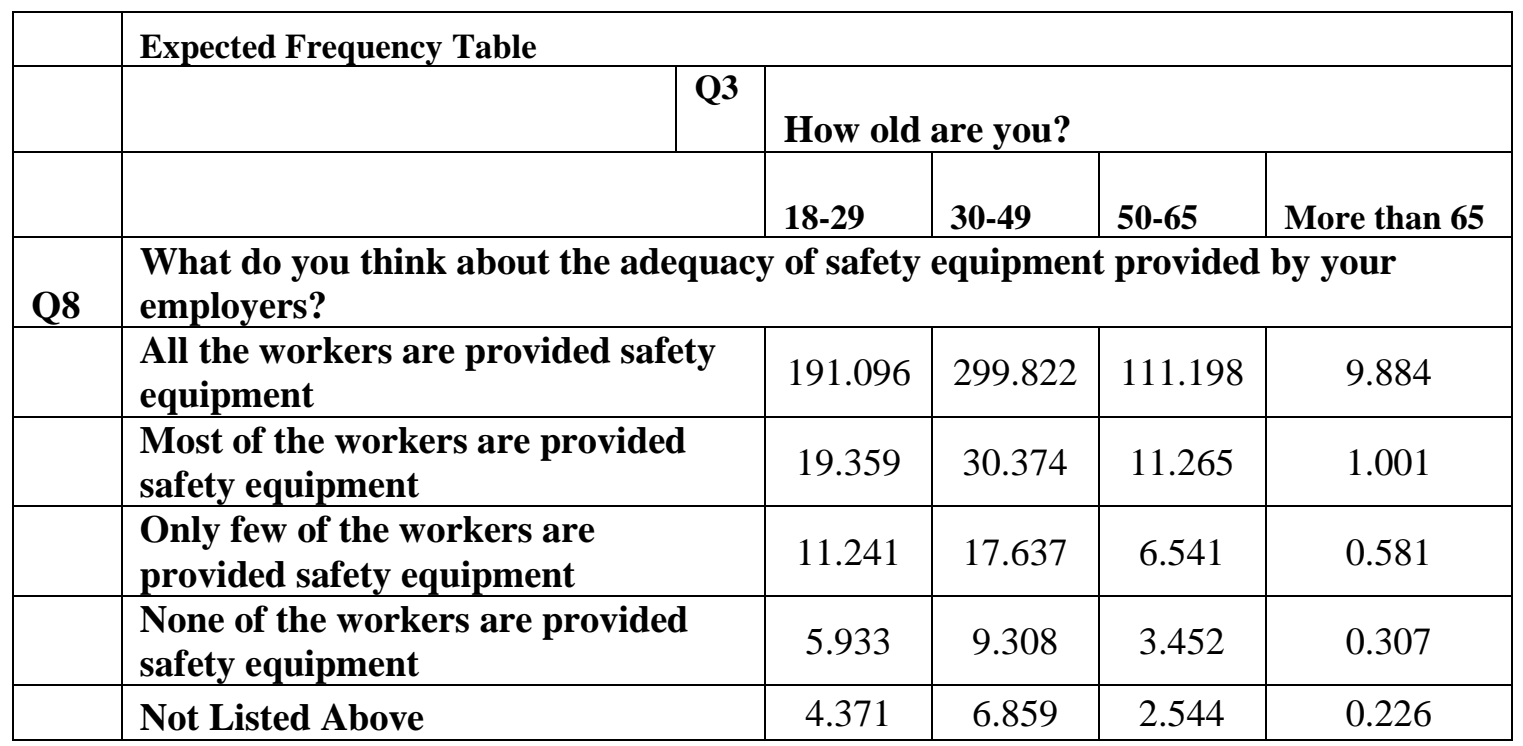

Table 14 below shows the Yates' Correction for the Chi-Square Test of Independence.

Table 14: Yates Correction Calculation Table for Q3 vs Q21

\begin{tabular}{|c|c|c|c|c|c|}
\hline & \multicolumn{5}{|c|}{ Yates Correction Calculation Table } \\
\hline & Q3 & \multicolumn{4}{|c|}{ How old are you? } \\
\hline & & 18-29 & $30-49$ & $50-65$ & More than 65 \\
\hline Q8 & \multicolumn{5}{|c|}{$\begin{array}{l}\text { What do you think about the adequacy of safety equipment provided by } \\
\text { your employers? }\end{array}$} \\
\hline \multicolumn{2}{|c|}{$\begin{array}{l}\text { All the workers are provided safety } \\
\text { equipment }\end{array}$} & 0.215 & 0.149 & 1.029 & 0.575 \\
\hline \multicolumn{2}{|c|}{$\begin{array}{l}\text { Most of the workers are provided } \\
\text { safety equipment }\end{array}$} & 0.179 & 0.322 & 0.277 & 0.248 \\
\hline \multicolumn{2}{|c|}{$\begin{array}{l}\text { Only few of the workers are } \\
\text { provided safety equipment }\end{array}$} & 0.006 & 2.888 & 7.404 & 0.011 \\
\hline \multicolumn{2}{|c|}{$\begin{array}{l}\text { None of the are provided safety } \\
\text { equipment }\end{array}$} & 0.346 & 0.153 & 0.001 & 0.122 \\
\hline \multicolumn{2}{|c|}{ Not Listed Above } & 0.801 & 2.770 & 9.657 & 7.177 \\
\hline \multicolumn{2}{|c|}{ Chi-Square Statistic Sum } & 34.32735 & & & \\
\hline \multicolumn{2}{|c|}{ Degree of Freedom } & 12 & & & \\
\hline \multicolumn{2}{|c|}{ P-value calculated } & 0.0006 & & & \\
\hline \multicolumn{2}{|c|}{ Significance Level } & 0.0500 & & & \\
\hline \multicolumn{2}{|c|}{ The result is significant at $p<0.05$} & & & & \\
\hline
\end{tabular}


The chi-square test shows that the variables are independent, and the result is significant at $95 \%$ confidence interval.

We wanted to evaluate how participants of different age groups report the adequacy of the safety equipment provided by the employers. The responses of the participants are represented by the "100\% stacked" chart below(Figure 35):

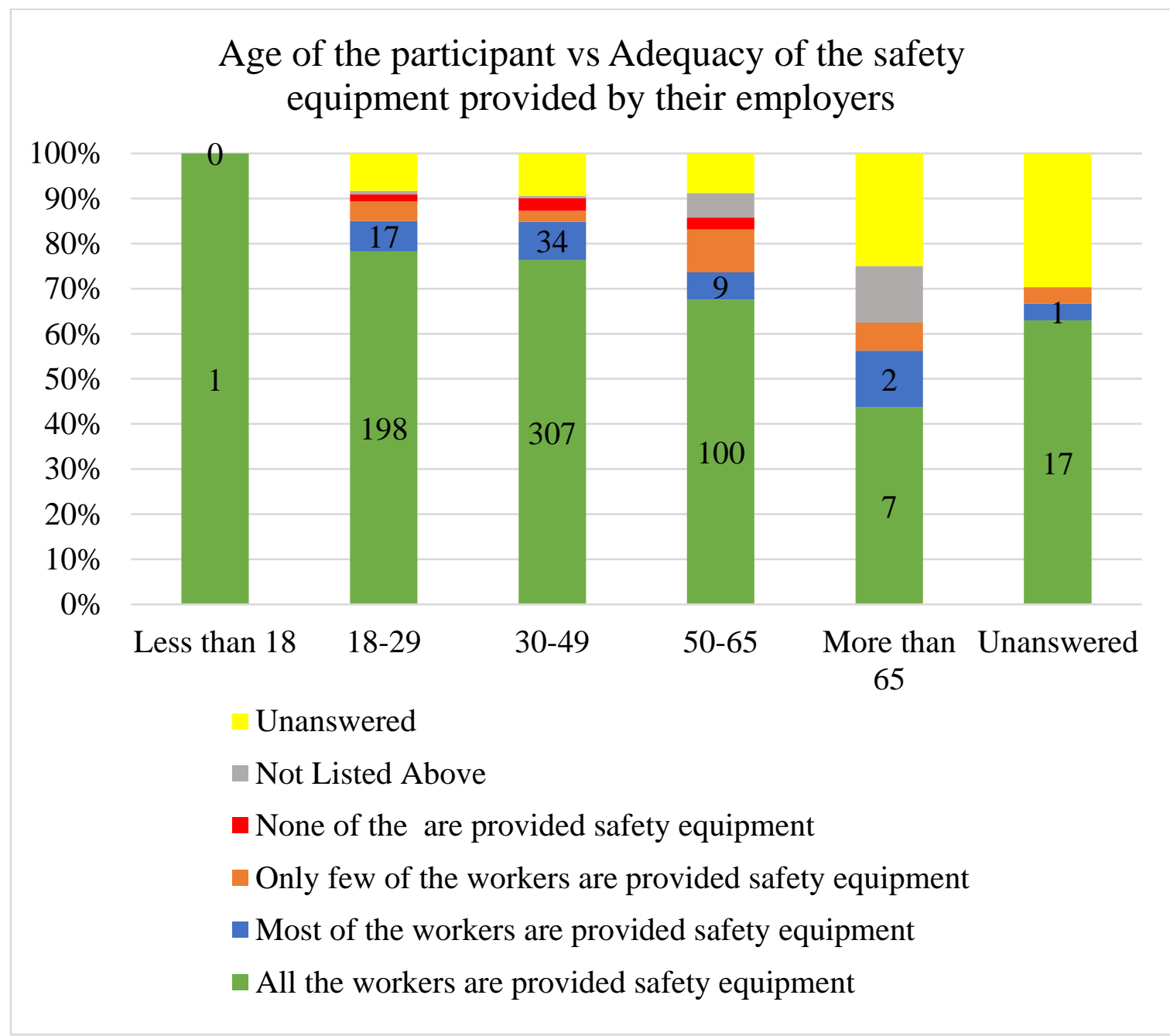

Figure 35: Age of the participant vs Adequacy of the safety equipment provided by their employers 
We observed that younger participants tend to say that all the workers are provided safety equipment compared to older participants. The age group of "Less than 18 " had only one participant. Hence, this group is included in the analysis done in this section. Participants of age-group 18-29 had the highest percentage who said that all the workers are provided safety equipment. The frequency of the participants who choose that response decreased as the age of the participants increased: about $78 \%$ for age-group " $18-29$ " to about $43 \%$ for age group "More than 65 ".

\subsection{Level of education vs. adequacy of knowledge about hazards and prevention measures}

We analyzed the participants' response to two of the questions asked in the questionnaire: "What is your level of education?" and "Do you feel you have adequate knowledge about hazards and prevention measures?". The first question inquiring about the years of experience of the participants allowed participants to choose one of these four categories: "School," "College degree," "Undergraduate degree," and "Graduate degree." The second question allowed participants to choose one of the three categories: "Yes," "Neutral," and "No.” Table 15: Observed Frequency Table for Q4 vs Q13 below shows the observed frequency of the responses to those two questions.

Table 15: Observed Frequency Table for Q4 vs Q13

\begin{tabular}{|c|c|c|c|c|c|c|}
\hline & \multicolumn{6}{|c|}{ Observed Frequency Table } \\
\hline & Q4 & \multicolumn{5}{|c|}{ What is your level of education? } \\
\hline & & School & $\begin{array}{l}\text { College } \\
\text { degree }\end{array}$ & $\begin{array}{l}\text { Undergraduate } \\
\text { degree }\end{array}$ & $\begin{array}{l}\text { Graduate } \\
\text { degree }\end{array}$ & Unanswered \\
\hline Q13 & \multicolumn{6}{|c|}{$\begin{array}{l}\text { Do you feel you have adequate knowledge about hazards and prevention } \\
\text { measures? }\end{array}$} \\
\hline & Yes & 266 & 122 & 47 & 96 & 38 \\
\hline & Neutral & 82 & 43 & 17 & 36 & 10 \\
\hline
\end{tabular}




\begin{tabular}{|l|l|r|r|r|r|r|}
\hline No & 8 & 3 & 8 & 4 & 1 \\
\hline & Unanswered & 24 & 10 & 3 & 15 & 14 \\
\hline
\end{tabular}

Table 16: Expected Frequency for Q4 vs. Q13 below shows the expected frequency calculated for the data. Data from the "Unanswered" category was not used in the analysis.

Table 16: Expected Frequency for Q4 vs. Q13

\begin{tabular}{|c|c|c|c|c|c|}
\hline & \multicolumn{5}{|c|}{ Expected Frequency } \\
\hline & \multirow[t]{2}{*}{ Q4 } & \multicolumn{4}{|c|}{ What is your level of education? } \\
\hline & & School & College degree & Undergraduate degree & Graduate degree \\
\hline Q13 & \multicolumn{5}{|c|}{$\begin{array}{l}\text { Do you feel you have adequate knowledge about hazards and prevention } \\
\text { measures? }\end{array}$} \\
\hline & Yes & 258.246 & 121.869 & 52.230 & 98.656 \\
\hline & Neutral & 86.568 & 40.852 & 17.508 & 33.071 \\
\hline & No & 11.186 & 5.279 & 2.262 & 4.273 \\
\hline
\end{tabular}


Table 17 below shows the Yates' Correction for the Chi-Square Test of Independence.

Table 17: Yates Correction Calculation Table for Q4 vs Q13

\begin{tabular}{|c|c|c|c|c|c|c|}
\hline & & \multicolumn{5}{|c|}{ Yates Correction Calculation Table } \\
\hline & Q4 & \multicolumn{5}{|c|}{ What is your level of education? } \\
\hline & & & 18-29 & $30-49$ & $50-65$ & More than 65 \\
\hline Q13 & \multicolumn{6}{|c|}{$\begin{array}{l}\text { Do you feel you have adequate knowledge about hazards and prevention } \\
\text { measures? }\end{array}$} \\
\hline & & Yes & 0.204 & 0.001 & 0.428 & 0.047 \\
\hline & & Neutral & 0.191 & 0.066 & 0.000 & 0.178 \\
\hline & & No & 0.645 & 0.599 & 12.126 & 0.012 \\
\hline \multicolumn{3}{|c|}{ Chi-Square Statistic Sum } & 14.49898 & & & \\
\hline \multicolumn{3}{|c|}{ Degree of Freedom } & 6 & & & \\
\hline \multicolumn{3}{|c|}{ P-value calculated } & 0.0006 & & & \\
\hline \multicolumn{3}{|c|}{ Significance Level } & 0.0500 & & & \\
\hline \multicolumn{3}{|c|}{$\begin{array}{l}\text { The result is significant at } p< \\
0.05\end{array}$} & & & & \\
\hline
\end{tabular}

The chi-square test shows that the variables are independent, and the result is significant at $95 \%$ confidence interval.

We wanted to evaluate how participants with different levels of education report their knowledge about hazards and prevention. The responses of the participants are represented by the " $100 \%$ stacked" chart below(Figure 36: Level of education vs adequacy of knowledge about hazards and prevention measures): 


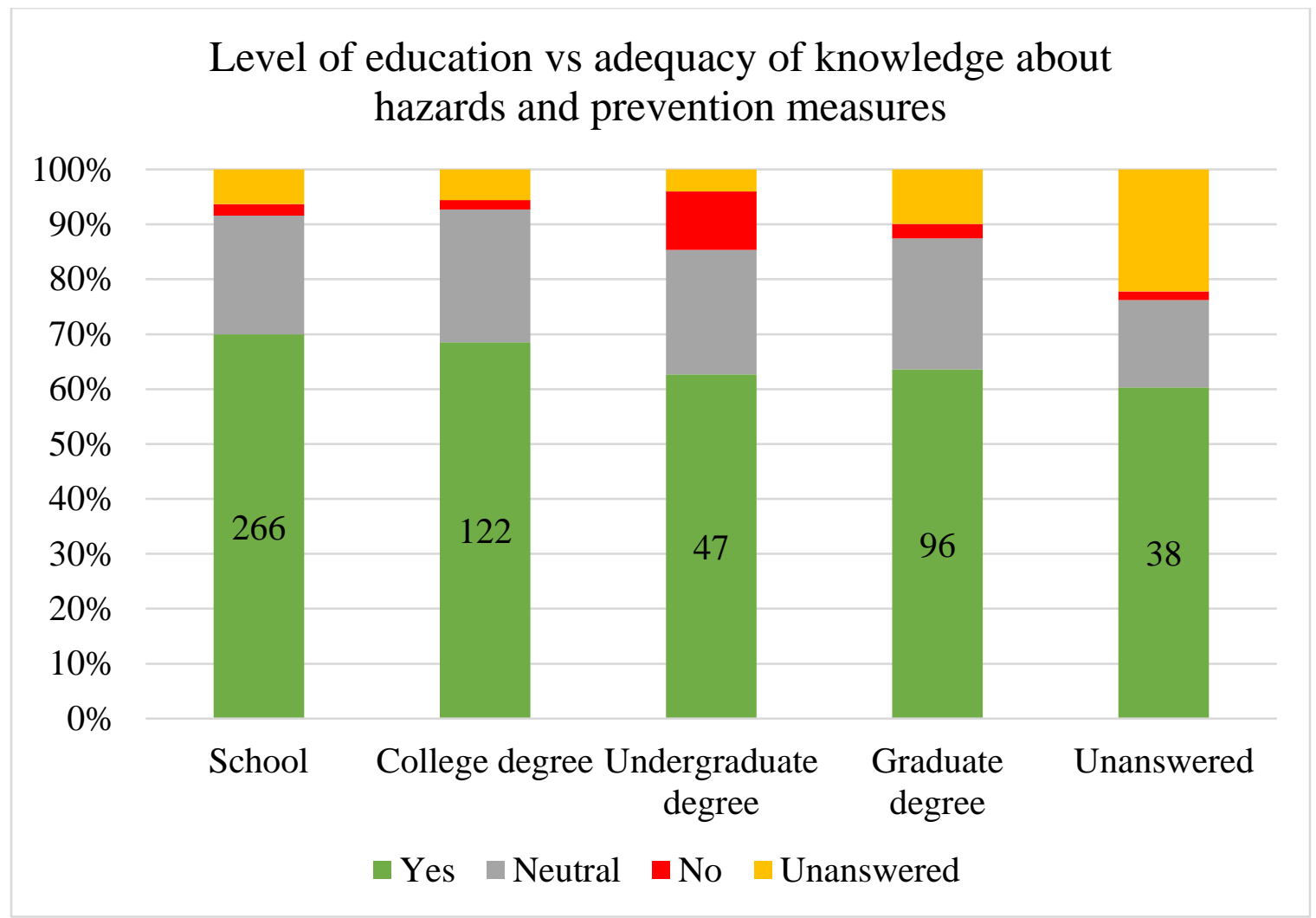

Figure 36: Level of education vs adequacy of knowledge about hazards and prevention measures

We observed that participants who had school level education were more inclined to say that they had adequate knowledge about hazards and prevention measures. About $70 \%$ of the participants choose that response compared to about $69 \%, 63 \%$ and $64 \%$ of participants with a college degree, an undergraduate degree and graduate degree respectively. This finding shows that more participants with a lower level of education feel that they have adequate knowledge about hazards and safety measures than participants with a higher level of education. 


\subsection{Provision of safety training on site by the employer vs Co-workers' safety habit}

We analyzed the participants' response to two of the questions asked in the questionnaire: "Does your employer provide training for safety on site?" and "Which of the following best explains your co-workers' safety habit?". The first question inquiring about the provision of safety training on site by the employer to the participants allowed participants to choose one of these three categories: "Yes," "Neutral," and "No." The second question allowed participants to choose one of the five categories: "All of them follow safety procedures," "Most of them follow safety procedures," "Some of them follow safety procedures," "None of them follow safety procedures," and "Not Listed Above." Table 18: Observed Frequency Table for Q19 vs Q8 below shows the observed frequency of the responses to those two questions.

Table 18: Observed Frequency Table for Q19 vs Q8

\begin{tabular}{|l|l|l|r|r|r|r|r|r|}
\hline \multicolumn{6}{|l|}{ Observed Frequency Table } \\
\hline & Q19 & Which of the following best explains your co-workers' safety habit? & \\
\hline & $\begin{array}{l}\text { All of them } \\
\text { follow safety } \\
\text { procedures }\end{array}$ & $\begin{array}{l}\text { Most of them } \\
\text { follow safety } \\
\text { procedures }\end{array}$ & $\begin{array}{l}\text { Some of } \\
\text { them follow } \\
\text { safety } \\
\text { procedures }\end{array}$ & $\begin{array}{l}\text { None of } \\
\text { them follow } \\
\text { safety } \\
\text { procedures }\end{array}$ & $\begin{array}{l}\text { Not } \\
\text { Listed } \\
\text { Above }\end{array}$ & $\begin{array}{l}\text { Una } \\
\text { nswe } \\
\text { red }\end{array}$ \\
\hline
\end{tabular}


Table 19 below shows the expected frequency calculated for the data. Data from the "Unanswered" category was not used in the analysis.

Table 19: Expected Frequency Table for Q19 vs Q8

\begin{tabular}{|l|l|l|l|l|l|l|}
\hline \multicolumn{6}{|l|}{ Expected Frequency Table } \\
\hline & Q19 & Which of the following best explains your co-workers' safety habit? \\
\hline & & $\begin{array}{l}\text { All of them } \\
\text { follow safety } \\
\text { procedures }\end{array}$ & $\begin{array}{l}\text { Most of them } \\
\text { follow safety } \\
\text { procedures }\end{array}$ & $\begin{array}{l}\text { Some of them } \\
\text { follow safety } \\
\text { procedures }\end{array}$ & $\begin{array}{l}\text { None of them } \\
\text { follow safety } \\
\text { procedures }\end{array}$ & \multicolumn{1}{l|}{$\begin{array}{l}\text { Not } \\
\text { Listed } \\
\text { Above }\end{array}$} \\
\hline
\end{tabular}

Table 20 below shows the Yates' Correction for the Chi-Square Test of Independence.

Table 20: Yates Correction Calculation Table for Q19 vs Q8

\begin{tabular}{|l|l|l|l|l|l|l|}
\hline & \multicolumn{7}{|c|}{ Yates Correction Calculation Table } \\
\hline & Q19 & \multicolumn{7}{|l|}{ Which of the following best explains your co-workers' safety habit? } \\
\hline & & $\begin{array}{l}\text { All of them } \\
\text { follow safety } \\
\text { procedures }\end{array}$ & $\begin{array}{l}\text { Most of them } \\
\text { follow safety } \\
\text { procedures }\end{array}$ & $\begin{array}{l}\text { Some of them } \\
\text { follow safety } \\
\text { procedures }\end{array}$ & $\begin{array}{l}\text { None of them } \\
\text { follow safety } \\
\text { procedures }\end{array}$ & $\begin{array}{l}\text { Not } \\
\text { Listed } \\
\text { Above }\end{array}$ \\
\hline
\end{tabular}


The chi-square test shows that the variables are independent, and the result is significant at $95 \%$ confidence interval.

We wanted to evaluate how the participants who are provided safety training on site respond to question about their co-workers' safety habit compared to the participants who are not provided safety training on site. The responses of the participants are represented by the "100\% stacked" chart below(Figure 37):

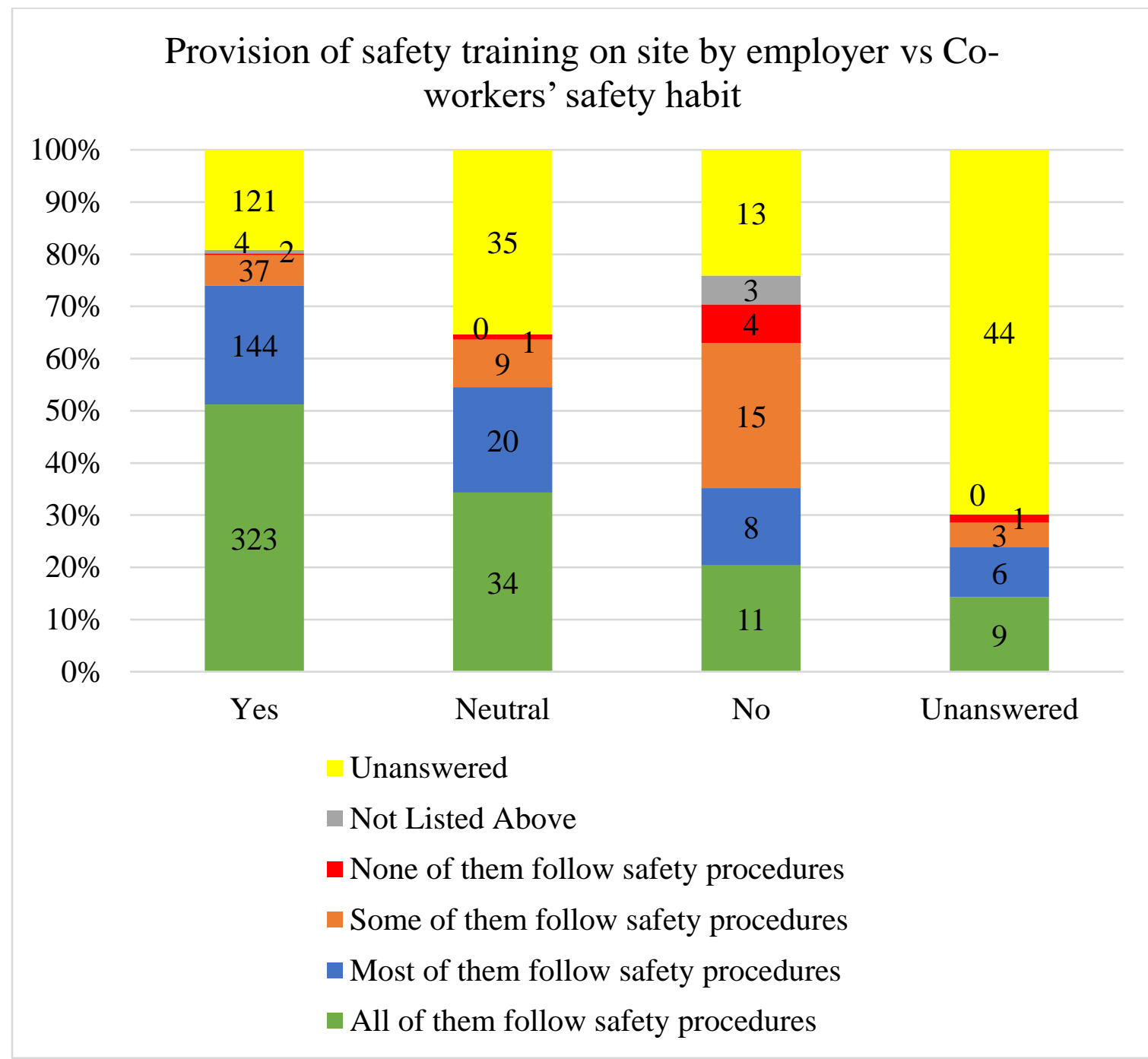

Figure 37: Provision of safety training on site by employer vs. Co-workers' safety habit 
We observed that about $51 \%$ percent of that participant who said that they were provided safety by the employers also said that all of their co-workers follow the safety procedures. Also, about $23 \%$ of the participants who said that they provide safety training by employers said that most of their co-workers follow safety procedures.

We also found that only about $20 \%$ of the participants who said their employers did not provide safety training on site also said that all their co-workers follow safety procedures. And, only about $15 \%$ of the participants who said their employers did not provide safety training said that most of their co-workers followed safety procedures.

This finding shows that participants who are provided safety training are more likely to see their co-workers follow safety procedures compared to participants who are not provided safety training on site.

\subsection{Provision of safety training on site by the employer vs Effect of co-workers' safety behavior}

We analyzed the participants' response to two of the questions asked in the questionnaire: "Does your employer provide training for safety on site?" and "Which of the following best explains your co-workers' safety habit?". The first question inquiring about the provision of safety training on site by the employer to the participants allowed participants to choose one of these three categories: "Yes," "Neutral," and "No." The second question allowed participants to choose one of the three categories: "If my coworkers do not follow safety procedures, I don't too", "I will follow what my co-workers do, unless I feel it is unsafe", and "I will always follow the safety procedures irrespective of my co-workers". 
Table 21 below shows the observed frequency of the responses to those two questions.

Table 21: Observed Frequency Table for Q21 vs Q6

\begin{tabular}{|l|l|l|l|l|r|r|}
\hline \multicolumn{6}{|l|}{ Observed Frequency Table } \\
\hline & Q21 & \begin{tabular}{l} 
How is your behavior affected by your co-workers' safety behavior? \\
\hline
\end{tabular} & $\begin{array}{l}\text { If my co-workers } \\
\text { do not follow } \\
\text { safety procedures, } \\
\text { I don't too. }\end{array}$ & $\begin{array}{l}\text { I will follow what } \\
\text { my co-workers do, } \\
\text { unless I feel it is } \\
\text { unsafe. }\end{array}$ & $\begin{array}{l}\text { I will always follow } \\
\text { the safety procedures } \\
\text { irrespective of my co- } \\
\text { workers. }\end{array}$ & Unanswered \\
\hline Q6 & Does your employer provide training for safety on site? & 453 & 136 \\
\hline & Yes & 7 & 35 & 53 & 30 \\
\hline & Neutral & 1 & 15 & 32 & 14 \\
\hline & No & 0 & 8 & 1 & 18 & 44 \\
\hline
\end{tabular}

Table 22 below shows the expected frequency calculated for the data. Data from the "Unanswered" category was not used in the analysis.

Table 22: Expected Frequency Table for Q3 vs Q6

\begin{tabular}{|l|l|l|l|l|}
\hline \multicolumn{5}{|l|}{ Expected Frequency Table } \\
\hline & Q21 & \multicolumn{2}{|l|}{ How is your behavior affected by your co-workers' safety behavior? } \\
\hline & & $\begin{array}{l}\text { If my co-workers do } \\
\text { not follow safety } \\
\text { procedures, I don't too. }\end{array}$ & $\begin{array}{l}\text { I will follow what my co- } \\
\text { workers do, unless I feel it is } \\
\text { unsafe. }\end{array}$ & $\begin{array}{l}\text { I will always follow the } \\
\text { safety procedures } \\
\text { irrespective of my co- } \\
\text { workers. }\end{array}$ \\
\hline
\end{tabular}


Table 23 below shows the Yates' Correction for the Chi-Square Test of Independence.

Table 23: Yates Correction Calculation Table for Q21 vs Q6

\begin{tabular}{|l|l|l|l|l|}
\hline \multicolumn{5}{|c|}{ Yates Correction Calculation Table } \\
\hline & Q21 & How is your behavior affected by your co-workers' safety behavior? \\
\hline & $\begin{array}{l}\text { If my co-workers do not } \\
\text { follow safety procedures, } \\
\text { I don't too. }\end{array}$ & $\begin{array}{l}\text { I will follow what my } \\
\text { co-workers do, unless I } \\
\text { feel it is unsafe. }\end{array}$ & $\begin{array}{l}\text { I will always follow the } \\
\text { safety procedures } \\
\text { irrespective of my co- } \\
\text { workers. }\end{array}$ \\
\hline Q6 & Does your employer provide training for safety on site? \\
\hline & Yes & 0.000 & 3.046 & 0.305 \\
\hline & Neutral & 0.187 & 9.358 & 1.031 \\
\hline & No & 0.002 & 3.485 & 0.275 \\
\hline Chi-Square Statistic Sum & $\mathbf{1 7 . 6 8 9 4 5}$ & \\
\hline Degree of Freedom & $\mathbf{4}$ & \\
\hline P-value calculated & $\mathbf{0 . 0 0 1 4}$ & \\
\hline Significance Level & $\mathbf{0 . 0 5 0 0}$ & \\
\hline The result is significant at $\mathbf{p}<\mathbf{0 . 0 5}$ & & \\
\hline
\end{tabular}

The chi-square test shows that the variables are independent, and the result is significant at $95 \%$ confidence interval.

We wanted to evaluate how the participants who are provided safety training on site respond about the effect of their coworkers' safety behavior compared to the participants who are not provided safety training on site. The responses of the participants are represented by the "100\% stacked" chart below (Figure 38): 


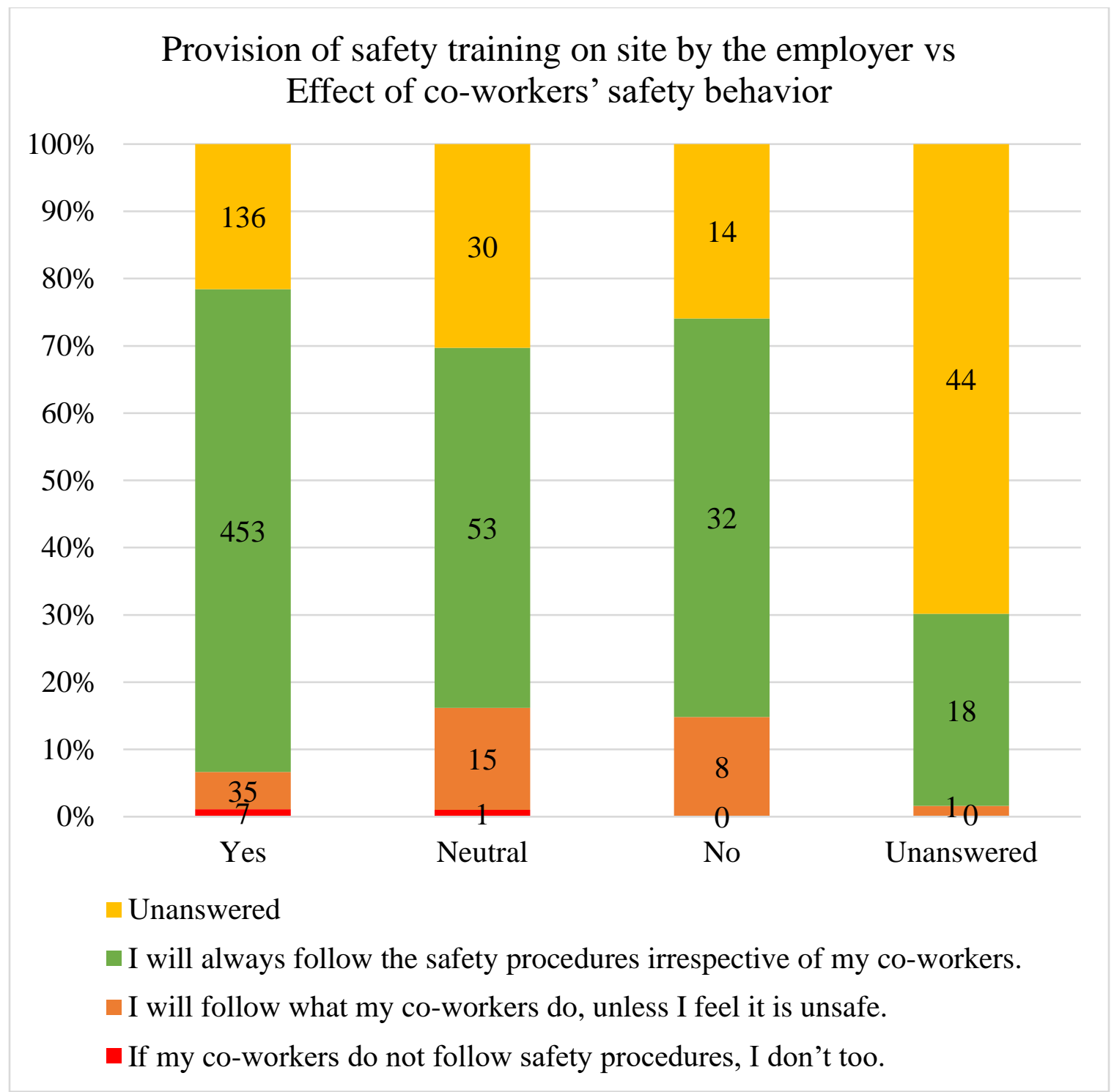

Figure 38: Provision of safety training on site by the employer vs. Effect of co-workers' safety behavior

We found that only about $6 \%$ of the participants who said they are provided safety training by their employers also said that they would follow their co-workers unless they feel it was unsafe. But about $72 \%$ of the participants who said that they are provided safety training by their employers said that they would follow the safety procedure irrespective of their co-workers. When compared to the participants who said that their employers did 
not provide safety training, about $15 \%$ of those participants said that they would follow their coworkers unless they feel it was unsafe, and only about $54 \%$ of them said that they would follow safety procedures irrespective of their co-workers.

This finding shows that participants who are provided safety training on the site are less likely to follow their co-workers and more likely to follow safety procedures.

\subsection{Strictness of the employer vs. Witnessing co-worker accident}

We analyzed the participants' response to two of the questions asked in the questionnaire: "How strict or lenient is your employer about safety measures?" and "Have you witnessed a co-worker having an accident due to fall hazards?". The first question inquiring about the strictness of the employer about safety measures allowed participants to choose one of these five categories: "Very Strict," "Strict," "Neutral," "Lenient," and "Very Lenient." The second question allowed participants to choose one of the three categories: "Yes," "Neutral," and "No." Table 24 shows the observed frequency of the responses for those two questions.

Table 24: Observed Frequency Table for Q20 vs Q9

\begin{tabular}{|l|l|l|l|r|l|}
\hline \multicolumn{7}{|l|}{ Observed Frequency Table } \\
\hline & \multicolumn{7}{l|}{ Have you witnessed a co-worker having an accident due to fall } \\
& Q20 & \multicolumn{2}{l|}{ Nazards? } \\
\hline & & Yes & Neutral & No & Unanswered \\
\hline Q9 & & How strict or lenient is your employer about safety measures? & 76 \\
\hline & Very Strict & 38 & 15 & 303 & 40 \\
\hline & Strict & 29 & 13 & 162 & 22 \\
\hline & Neutral & 9 & 10 & 49 & 3 \\
\hline & Lenient & 5 & 0 & 7 & \\
\hline
\end{tabular}




\begin{tabular}{|l|l|r|r|r|r|}
\hline & Very & 1 & 2 & 1 & 1 \\
\hline Lenient & 1 & 1 & 7 & 52 \\
\hline
\end{tabular}

Table 25 below shows the expected frequency calculated for the data. Data from the "Unanswered" category was not used in the analysis.

Table 25: Expected Frequency Table for Q20 vs Q9

\begin{tabular}{|l|l|r|r|r|}
\hline \multicolumn{4}{|l|}{ Expected Frequency Table } \\
\hline & Q20 & \multicolumn{4}{l|}{$\begin{array}{l}\text { Have you witnessed a co-worker having an accident due to fall } \\
\text { hazards? }\end{array}$} & \multicolumn{2}{|c|}{ Yes } & \multicolumn{2}{c|}{ Neutral } & No \\
\hline & \multicolumn{4}{|c|}{ How strict or lenient is your employer about safety measures? } \\
\hline Q9 & & 45.329 & 22.112 & 288.559 \\
\hline & Very Strict & 25.975 & 12.671 & 165.354 \\
\hline & Strict & 8.658 & 4.224 & 55.118 \\
\hline & Neutral & 1.528 & 0.745 & 9.727 \\
\hline & Lenient & 0.509 & 0.248 & 3.242 \\
\hline
\end{tabular}


Table 26 below shows the Yates' Correction for the Chi-Square Test of Independence.

Table 26: Yates Correction Calculation Table for Q20 vs Q9

\begin{tabular}{|c|c|c|c|c|c|}
\hline & \multicolumn{5}{|c|}{ Yates Correction Calculation Table } \\
\hline & \multirow[t]{2}{*}{ Q20 } & & \multicolumn{3}{|c|}{$\begin{array}{l}\text { Have you witnessed a co-worker having an accident due to fall } \\
\text { hazards? }\end{array}$} \\
\hline & & & Yes & Neutral & No \\
\hline \multicolumn{2}{|l|}{ Q9 } & \multicolumn{4}{|c|}{ How strict or lenient is your employer about safety measures? } \\
\hline & Very Strict & & 1.029 & 1.977 & 0.674 \\
\hline & Strict & & 0.245 & 0.002 & 0.049 \\
\hline & Neutral & & 0.003 & 6.592 & 0.573 \\
\hline & Lenient & & 5.781 & 0.081 & 0.510 \\
\hline & Very Lenient & & 0.000 & 6.305 & 0.936 \\
\hline \multicolumn{4}{|c|}{ Chi-Square Statistic Sum } & 24.756 & \\
\hline \multicolumn{4}{|c|}{ Degree of Freedom } & 8 & \\
\hline \multicolumn{4}{|c|}{ P-value calculated } & 0.0017 & \\
\hline \multicolumn{4}{|c|}{ Significance Level } & 0.0500 & \\
\hline \multicolumn{4}{|c|}{ The result is significant at $\mathrm{p}<0.05$} & & \\
\hline
\end{tabular}

The chi-square test shows that the variables are independent, and the result is significant at $95 \%$ confidence interval.

We wanted to evaluate how the strictness of the employers about safety measures affects whether the participants witness a co-worker accident due to fall hazards or not. The responses of the participants are represented by the " $100 \%$ stacked" chart below(Figure 39: Strictness of the employer vs. Witnessing co-worker accident): 


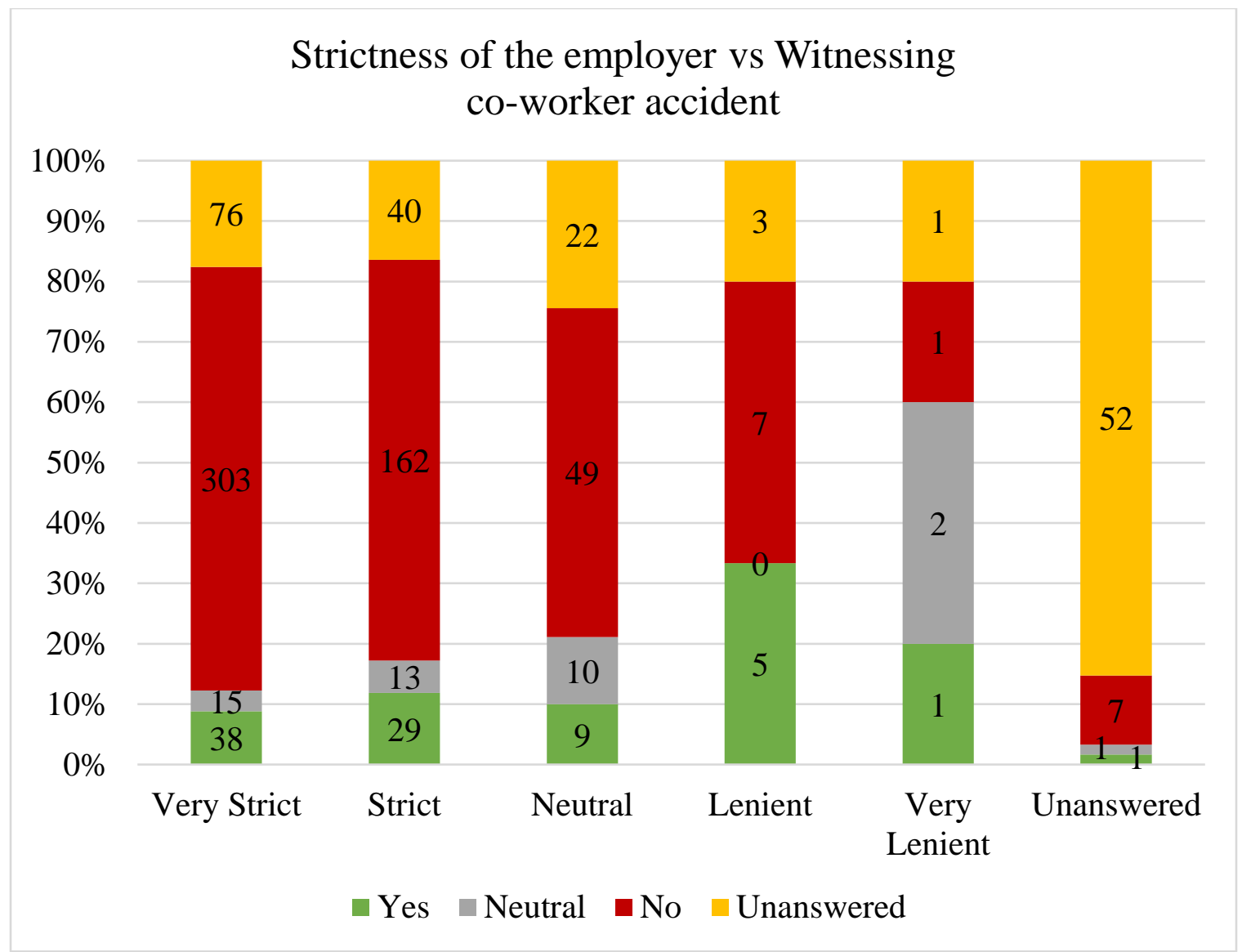

Figure 39: Strictness of the employer vs. Witnessing co-worker accident

We found that only about $9 \%$ of participants who said that their employers were "Very Strict" about safety measures also said that they had witnessed a co-worker accident due to fall hazards. But about $70 \%$ of those participants said that they had not witnessed a coworker accident due to fall hazards. Among the participants who said that their employers were "Strict," about $12 \%$ admitted to witnessing a co-worker's accident and about $66 \%$ said they had not witnessed a co-worker's accident.

About 33\% of the participants who said their employers were "Lenient" about safety measures also said that they had witnessed a co-worker's accident. About $46 \%$ of those participants said they had not witnessed a co-worker accident. Among the participants who 
said that their employers were "Very Lenient," about 20\% said they had witnessed a coworker accident, and about $20 \%$ said that they had not witnessed a co-worker accident due to fall hazards.

This finding shows that a lesser number of participants who work for stricter employer witness a co-worker accident compared to participants who work for a more lenient employer.

\subsection{Provision of safety training on site from employer VS Participants self-acknowledged adequacy of knowledge about hazards and prevention measures}

We analyzed the participants' response to two of the questions asked in the questionnaire: "Does your employer provide training for safety on site?" and "Do you feel you have adequate knowledge about hazards and prevention measures?". The first question inquiring about the provision of safety training on site by the employer to the participants allowed participants to choose one of these three categories: "Yes," "Neutral," and "No." The second question inquiring about the participants' perspective about their own knowledge about hazards and prevention measures, allowed participants to choose one of the same three categories as above: "Yes," "Neutral," and "No." Table 27: Observed Frequency Table for Q13 vs Q6 below shows the observed frequency of the responses to those two questions.

Table 27: Observed Frequency Table for Q13 vs Q6

\begin{tabular}{|l|l|l|l|l|l|}
\hline & \multicolumn{3}{|l|}{ Observed Frequency Table } \\
\hline Q13 & $\begin{array}{l}\text { Do you feel you have adequate knowledge about hazards and prevention } \\
\text { measures? }\end{array}$ & Yes & Neutral & No & Unanswered \\
\hline & \multicolumn{5}{|l|}{} \\
\hline
\end{tabular}




\begin{tabular}{|l|l|r|r|r|r|}
\hline \multicolumn{2}{|l|}{ Q6 } & Does your employer provide training for safety on site? \\
\hline & Yes & 467 & 124 & 8 & 32 \\
\hline Neutral & 49 & 37 & 6 & 7 \\
\hline No & 29 & 13 & 9 & 3 \\
\hline Unanswered & 24 & 14 & 1 & 24 \\
\hline
\end{tabular}

Table 28: Expected Frequency Table for Q13 vs Q6 below shows the expected frequency calculated for the data. Data from the "Unanswered" category was not used in the analysis.

Table 28: Expected Frequency Table for Q13 vs Q6

\begin{tabular}{|l|l|l|r|r|r|}
\hline \multicolumn{6}{|l|}{ Expected Frequency Table } \\
\hline & Q13 & $\begin{array}{l}\text { Do you feel you have adequate knowledge about hazards and prevention } \\
\text { measures? }\end{array}$ & \multicolumn{1}{|l|}{ Yes } & Neutral & \multicolumn{1}{|l|}{ No } \\
\hline & & & 439.966 & 140.466 & 18.567 \\
\hline Q6 & Does your employer provide training for safety on site? & 21.574 & 2.852 \\
\hline & Yes & 67.574 & 11.960 & 1.581 \\
\hline & Neutral & & 37.460 & & \\
\hline & No & & & &
\end{tabular}


Table 29 below shows the Yates' Correction for the Chi-Square Test of Independence.

Table 29: Yates Correction Calculation Table for Q13 vs Q6

\begin{tabular}{|l|l|r|r|r|}
\hline \multicolumn{5}{|l|}{ Yates Correction Calculation Table } \\
\hline & $\begin{array}{l}\text { Do you feel you have adequate knowledge about hazards and prevention } \\
\text { measures? }\end{array}$ & \multicolumn{1}{|l|}{ Yes } & Neutral & No \\
\hline & \multicolumn{3}{|l|}{} \\
\hline Q6 & Does your employer provide training for safety on site? \\
\hline & Yes & 1.600 & 1.815 & 5.459 \\
\hline & Neutral & 4.834 & 10.326 & 2.459 \\
\hline & No & 1.691 & 0.024 & 30.284 \\
\hline Chi-Square Statistic Sum & & $\mathbf{5 8 . 4 9 3 0 4}$ & \\
\hline Degree of Freedom & & $\mathbf{4}$ & \\
\hline P-value calculated & $\mathbf{0 . 0 0 0 0 1}$ & \\
\hline Significance Level & $\mathbf{0 . 0 5 0 0}$ & \\
\hline The result is significant at p $<\mathbf{0 . 0 5}$ & & \\
\hline
\end{tabular}

The chi-square test shows that the variables are independent, and the result is significant at $95 \%$ confidence interval.

We wanted to evaluate how the participants who are provided safety training on site acknowledge whether they have adequate safety knowledge or not, compared to the participants who are not provided safety training on site. The responses of the participants are represented by the "100\% stacked" chart below(Figure 40): 


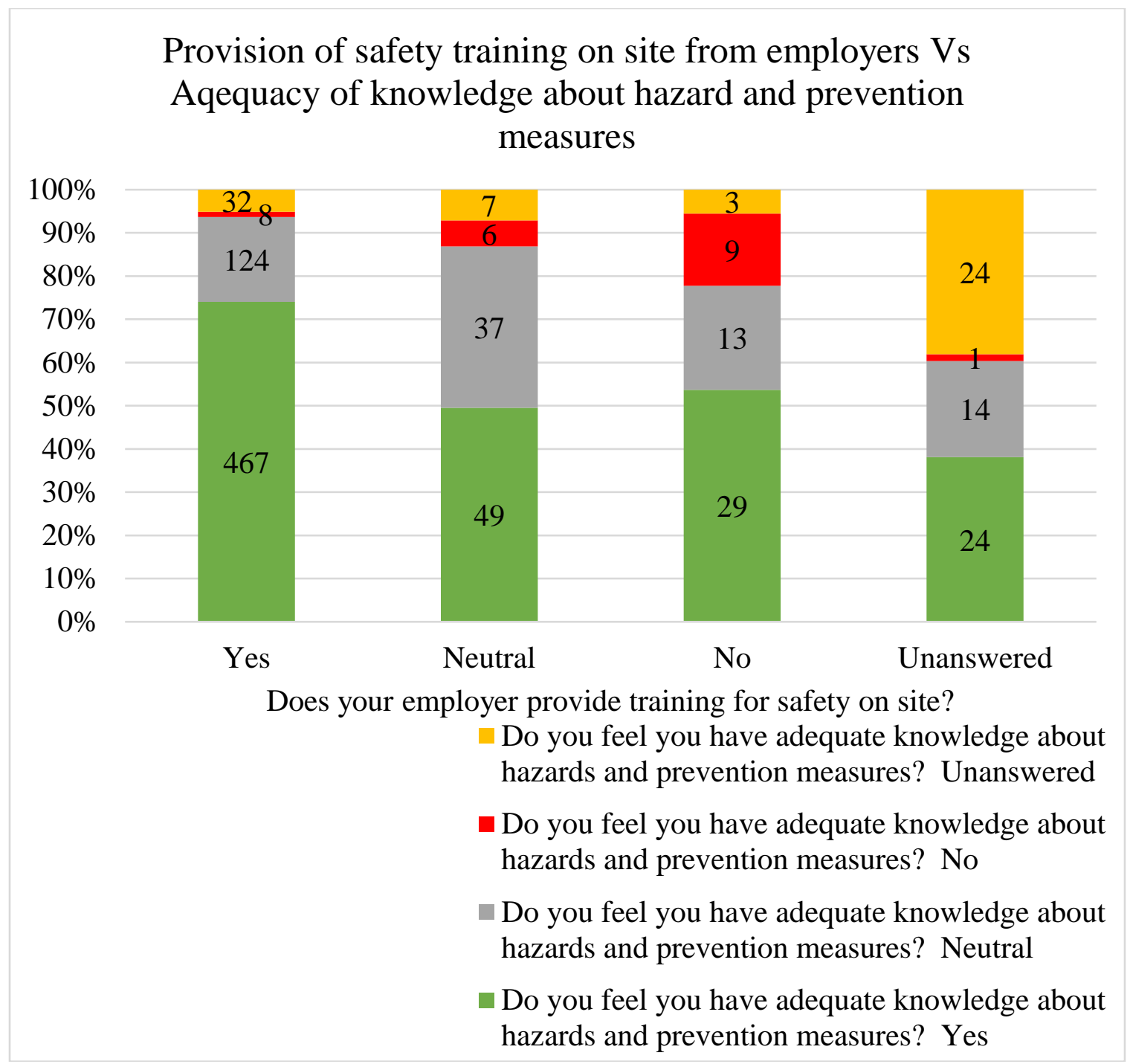

Figure 40: Provision of safety training on site from employers Vs. Adequacy of knowledge about hazard and prevention measures

We observed that about $74 \%$ of the participants who say that their employers provide training for safety on site also said that they have adequate knowledge about hazards and safety measures whereas only about $13 \%$ of those participants said that they did not feel that they had adequate knowledge about hazards and safety measures.

When compared to the participants who said that their employers did not provide safety training on site, about 54\% said that they feel they had adequate knowledge about hazards 
and safety measures, and about $16 \%$ said that they did not feel they had adequate knowledge about hazards and safety measures.

This finding shows that participants who are provided safety training by the employers are more likely to feel that they have adequate knowledge about safety hazards and prevention measures compared to participants who are not provided safety training.

\subsection{Strictness of the employer VS Co-workers' safety habit}

We analyzed the participants' response to two of the questions asked in the questionnaire: "How strict or lenient is your employer about safety measures?" and "Which of the following best explains your co-workers' safety habit?". The first question inquiring about the strictness of the employer about safety measures allowed participants to choose one of these five categories: "Very Strict," "Strict," "Neutral," "Lenient," and "Very Lenient." The second question allowed participants to choose one of the five categories: "All of them follow safety procedures," "Most of them follow safety procedures," "Some of them follow safety procedures," "None of them follow safety procedures," and "Not Listed Above." Table 30 below shows the observed frequency of the responses for those two questions. 
Table 30: Observed Frequency Table for Q19 vs Q9

\begin{tabular}{|c|c|c|c|c|c|c|c|}
\hline \multicolumn{8}{|c|}{ Observed Frequency Table } \\
\hline & \multirow{2}{*}{ Q19 } & \multicolumn{6}{|c|}{ Which of the following best explains your co-workers' safety habit? } \\
\hline & & $\begin{array}{l}\text { All of them } \\
\text { follow safety } \\
\text { procedures }\end{array}$ & $\begin{array}{l}\text { Most of them } \\
\text { follow safety } \\
\text { procedures }\end{array}$ & $\begin{array}{l}\text { Some of them } \\
\text { follow safety } \\
\text { procedures }\end{array}$ & $\begin{array}{l}\text { None of them } \\
\text { follow safety } \\
\text { procedures }\end{array}$ & $\begin{array}{l}\text { Not } \\
\text { Listed } \\
\text { Above }\end{array}$ & $\begin{array}{l}\text { Unans } \\
\text { wered }\end{array}$ \\
\hline Q & & \multicolumn{6}{|c|}{ How strict or lenient is your employer about safety measures? } \\
\hline & $\begin{array}{l}\text { Very } \\
\text { Strict }\end{array}$ & 265 & 65 & 17 & 3 & 1 & 81 \\
\hline & Strict & 78 & 93 & 23 & 0 & 3 & 47 \\
\hline & Neutral & 22 & 16 & 18 & 2 & 3 & 29 \\
\hline & Lenient & 4 & 1 & 6 & 1 & 0 & 3 \\
\hline & $\begin{array}{l}\text { Very } \\
\text { Lenient }\end{array}$ & 1 & 2 & 0 & 1 & 0 & 1 \\
\hline & $\begin{array}{l}\text { Unanswe } \\
\text { red }\end{array}$ & 7 & 1 & 0 & 1 & 0 & 52 \\
\hline
\end{tabular}

Table 31 below shows the expected frequency calculated for the data. Data from the "Unanswered" category was not used in the analysis.

Table 31: Expected Frequency Table for Q19 vs Q9

\begin{tabular}{|l|l|l|l|l|l|l|}
\hline \multicolumn{6}{|l|}{ Expected Frequency Table } \\
\hline Q19 & \multicolumn{2}{|l|}{ Which of the following best explains your co-workers' safety habit? } \\
\hline & $\begin{array}{l}\text { All of them } \\
\text { follow safety } \\
\text { procedures }\end{array}$ & $\begin{array}{l}\text { Most of them } \\
\text { follow safety } \\
\text { procedures }\end{array}$ & $\begin{array}{l}\text { Some of them } \\
\text { follow safety } \\
\text { procedures }\end{array}$ & $\begin{array}{l}\text { None of them } \\
\text { follow safety } \\
\text { procedures }\end{array}$ & $\begin{array}{l}\text { Not } \\
\text { Listed } \\
\text { Above }\end{array}$ \\
\hline Q9 & How strict or lenient is your employer about safety measures? & \\
\hline $\begin{array}{l}\text { Very } \\
\text { Strict }\end{array}$ & 207.792 & 99.403 & 35.942 & 3.931 & 3.931 \\
\hline Strict & 116.624 & 55.790 & 20.173 & 2.206 & 2.206 \\
\hline $\begin{array}{l}\text { Neutr } \\
\text { al }\end{array}$ & 36.112 & 17.275 & 0.246 & 0.683 & 0.683 \\
\hline $\begin{array}{l}\text { Lenie } \\
\text { nt }\end{array}$ & 7.104 & 3.3984 & 1.229 & 0.134 & 0.134 \\
\hline $\begin{array}{l}\text { Very } \\
\text { Lenie } \\
\text { nt }\end{array}$ & 2.368 & 1.1328 & & & \\
\hline
\end{tabular}


Table 32 below shows the Yates' Correction for the Chi-Square Test of Independence.

\begin{tabular}{|c|c|c|c|c|c|}
\hline Yates C & $\begin{array}{r}\text { Table 32: Y } \\
\text { Correction Calcul }\end{array}$ & $\begin{array}{l}\text { ates Correction C } \\
\text { tion Table }\end{array}$ & lculation Table & or Q19 vs Q9 & \\
\hline & Which of the fol & wing best explai & s your co-worker & ' safety habit? & \\
\hline & $\begin{array}{l}\text { All of them } \\
\text { follow safety } \\
\text { procedures }\end{array}$ & $\begin{array}{l}\text { Most of them } \\
\text { follow safety } \\
\text { procedures }\end{array}$ & $\begin{array}{l}\text { Some of them } \\
\text { follow safety } \\
\text { procedures }\end{array}$ & $\begin{array}{l}\text { None of them } \\
\text { follow safety } \\
\text { procedures }\end{array}$ & $\begin{array}{l}\text { Not } \\
\text { Listed } \\
\text { Above } \\
\end{array}$ \\
\hline Q9 & w strict or lenien & is your employer & about safety meas & Ires? & \\
\hline $\begin{array}{l}\text { Very } \\
\text { Strict } \\
\end{array}$ & 15.47604 & 11.563 & 9.463 & 0.047 & 1.503 \\
\hline Strict & 12.46261 & 24.155 & 0.268 & 1.320 & 0.039 \\
\hline Neutral & 5.130886 & 0.035 & 20.275 & 0.977 & 4.831 \\
\hline Lenient & 0.954507 & 1.060476 & 14.846 & 0.995 & 0.995 \\
\hline $\begin{array}{l}\text { Very } \\
\text { Lenient }\end{array}$ & 0.318169 & 0.119029 & 0.020 & 4.625 & 4.62 \\
\hline Chi-Squar & re Statistic Sum & & 136.104 & & \\
\hline Degree of & Freedom & & 16 & & \\
\hline P-value ca & Iculated & & $<0.00001$ & & \\
\hline Significan & ce Level & & 0.0500 & & \\
\hline The result & $t$ is significant at & $<0.05$ & & & \\
\hline
\end{tabular}

The chi-square test shows that the variables are independent, and the result is significant at $95 \%$ confidence interval.

We wanted to evaluate how the strictness of the employers about safety measures affects the coworkers' safety habit reported by the. The responses of the participants are represented by the " $100 \%$ stacked" chart below(Figure 41): 


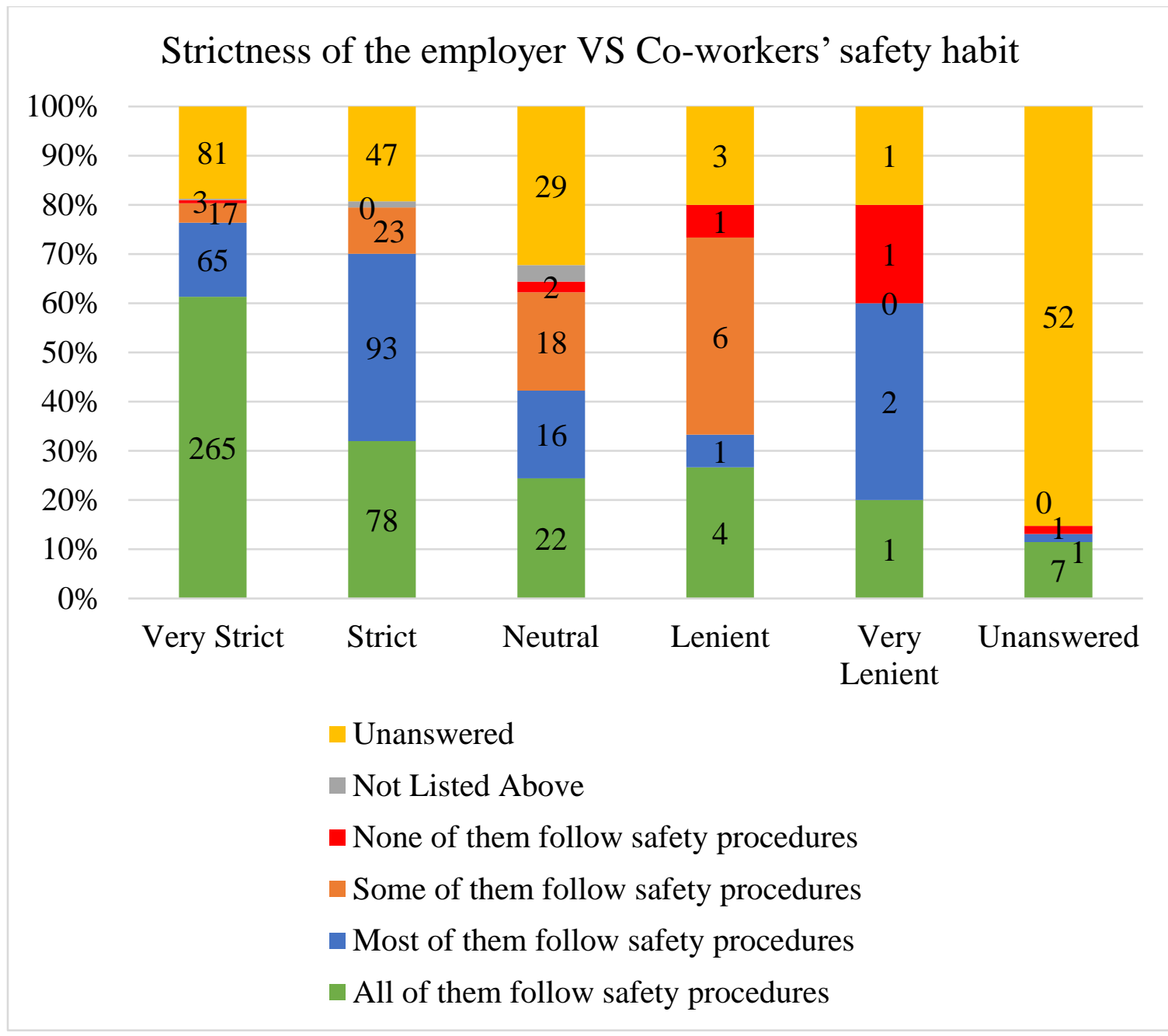

Figure 41: Strictness of the employer VS Co-workers' safety habit

We observed that about $76 \%$ of the participants who said that their employers were "Very strict" about safety procedures also said that all or most of their co-workers followed safety procedures. Lesser percentage, about $70 \%$ of the participants who said that their employers were "Strict" about the safety procedures also said that all or most of their coworkers followed safety procedures. About $42 \%$ of participants who chose the "Neutral" option for the strictness of their employers also said that all or most of their coworkers follow safety procedures. The percentage further decreased to about $27 \%$ for participants 
who said that their employers were "Lenient" and all or most of their coworkers followed safety procedures. The "Very Lenient" category did not follow the decreasing trend which may be the effect of having the least number of participants in this category.

Overall, this shows that participants whose employers are stricter about the safety measures are more likely to have coworkers who follow safety procedures compared to participants with lenient employers.

\subsection{Provision of training from the employer VS Witnessing a co-worker's accident}

We analyzed the participants' response to two of the questions asked in the questionnaire: "Does your employer provide training for safety on site?" and "Which of the following best explains your co-workers' safety habit?". The first question inquiring about the provision of safety training on site by the employer to the participants allowed participants to choose one of these three categories: "Yes," "Neutral," and "No." The second question allowed participants to choose one of the three categories: "If my coworkers do not follow safety procedures, I don't too", "I will follow what my co-workers do, unless I feel it is unsafe", and "I will always follow the safety procedures irrespective of my co-workers". Table 33 below shows the observed frequency of the responses to those two questions. 
Table 33: Observed Frequency Table for Q20 vs Q6

\begin{tabular}{|c|c|c|c|c|c|}
\hline & \multicolumn{5}{|c|}{ Observed Frequency Table } \\
\hline & \multirow[t]{2}{*}{ Q20 } & \multicolumn{4}{|c|}{$\begin{array}{l}\text { Have you witnessed a co-worker having an accident due to fall } \\
\text { hazards? }\end{array}$} \\
\hline & & Yes & Neutral & No & Unanswered \\
\hline Q6 & \multicolumn{5}{|c|}{ Does your employer provide training for safety on site? } \\
\hline & Yes & 64 & 25 & 429 & 113 \\
\hline & Neutral & 10 & 10 & 53 & 26 \\
\hline & No & 8 & 3 & 31 & 12 \\
\hline & Unanswered & 1 & 3 & 16 & 43 \\
\hline
\end{tabular}

Table 34 below shows the expected frequency calculated for the data. Data fromthe "Unanswered" category was not used in the analysis.

Table 34: Expected Frequency Table for Q20 vs Q6

\begin{tabular}{|l|l|l|l|r|}
\hline & \multicolumn{4}{|l|}{ Expected Frequency Table } \\
\hline & Q20 & Have you witnessed a co-worker having an accident due to fall hazards? \\
\hline & & Yes & Neutral & No \\
\hline Q6 & Does your employer provide training for safety on site? \\
\hline & Yes & 67.1027 & 31.0964 & 419.8009 \\
\hline & Neutral & 9.4566 & 4.3823 & 59.1611 \\
\hline & No & 5.4408 & 2.5213 & 34.0379 \\
\hline
\end{tabular}


Table 35 below shows the Yates' Correction for the Chi-Square Test of Independence.

Table 35: Yates Correction Calculation Table for Q20 vs Q6

\begin{tabular}{|l|l|l|r|r|}
\hline \multicolumn{5}{|l|}{ Yates Correction Calculation Table } \\
\hline & Q20 & Have you witnessed a co-worker having an accident due to fall hazards? \\
\hline & Yes & \multicolumn{1}{|l|}{ Neutral } & \multicolumn{1}{|c|}{ No } \\
\hline & Q6 & Does your employer provide training for safety on site? & 0.180 \\
\hline & Yes & 0.101 & 1.007 & 0.542 \\
\hline & Neutral & 0.000 & 5.976 & 0.189 \\
\hline & No & 0.779 & 0.000 & $\mathbf{8 . 7 7 5 5 8 0 2}$ \\
\hline Chi-Square Statistic Sum & & $\mathbf{4}$ \\
\hline Degree of Freedom & $\mathbf{0 . 0 6 6 9 7 6}$ \\
\hline P-value calculated & $\mathbf{0 . 1 0 0}$ \\
\hline Significance Level & \\
\hline
\end{tabular}

The chi-square test shows that the variables are independent, and the result is significant at a $90 \%$ confidence interval.

We wanted to evaluate how the participants who are provided safety training on site respond about the effect of their coworkers' safety behavior compared to the participants who are not provided safety training on site. The responses of the participants are represented by the " $100 \%$ stacked" chart below(Figure 42: Provision of training from the employer VS Witnessing a co-worker's accident): 


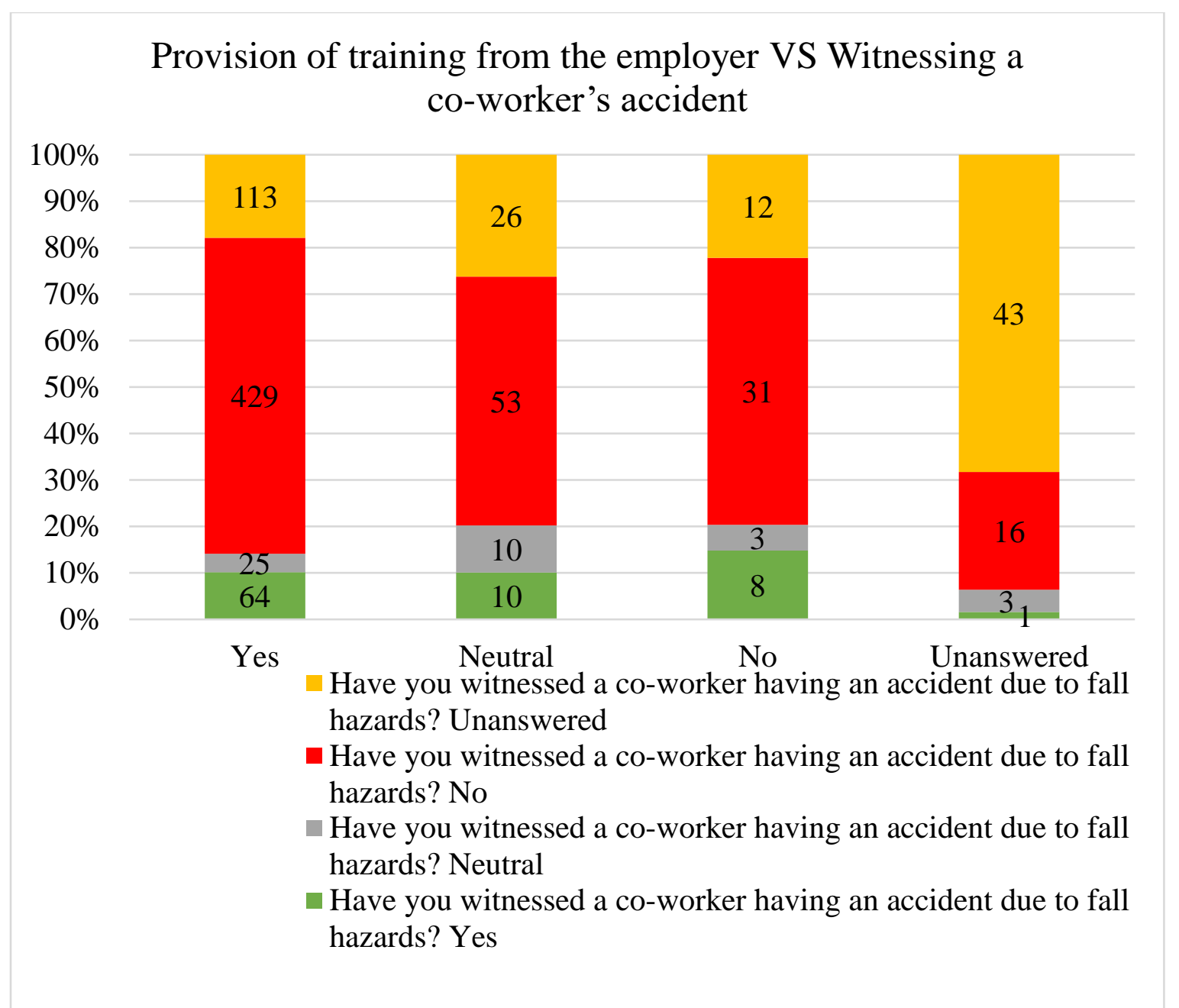

Figure 42: Provision of training from the employer VS Witnessing a co-worker's accident

We observed that among the participants who said that their employers provide safety training, about $10 \%$ said that they had witnessed a co-worker having an accident whereas about $68 \%$ of those participants said that they had not witnessed a co-worker having an accident.

We also found that among the participants who said they were not provided safety training, about $14 \%$ said that they had witnessed a co-worker having an accident whereas 
about $57 \%$ of those participants said that they had not witnessed a co-worker having an accident.

This finding shows that participants who are provided safety training by the employers are less likely to witness a co-worker having an accident due to fall hazards compared to participants who are not provided safety training.

\subsection{Results}

\subsubsection{Perspective Trends}

The first section of the questionnaire inquired about the participants' attributes in terms of their role, age, years of experience and education level. Electricians made the largest group who took part in the training. They were followed by plumbers and laborers. Lessexperienced participants made the majority group participating in the fall training program. There was lower participation from construction professionals with higher experience. Participants of age 30-49 made the majority who came to the training. There was very low participation from the construction professionals of 65 years of age or more. Construction professionals with school education made the majority of participants in fall training.

The second section inquired about the safety culture of the employers of the participants. Employers were seen lenient in terms of requiring safety certificate for a job as the higher number of participants said that they sometimes need safety training certificate to get a job compared to the participants who always or most of the time need safety training certificate. Verbal instructions were the most common form of safety training provided by employers whereas audio-visual presentations were the least common. About $80 \%$ of the participants saw their employers as very strict or strict about safety 
measures. However, $30 \%$ of participants also said that they don't get noticed for not following the safety procedures on site. While only a quarter of participants said that their employers rewarded them for following safety procedures, more than half of them said that they would be encouraged to follow safety procedures if rewarded.

The third section of the questionnaire inquired about the participants' own safety habit. About two-thirds of the participants felt that they had enough knowledge of hazards and prevention measures. More than half of the participants said that they encounter fall hazards on a daily or weekly basis. Knee level height was the most common answer for safe height to stand on an unprotected surface or edge. Safety boots were the safety equipment most participants said they always wear while working followed by hard hats. Ear Plugs and Body harness were the more common safety equipment which the participants never wore. Reducing the ability to work, restricting movement and ill-fitting were the top three reasons for not wearing safety equipment. "Not required for my job" or "Not always required" were the most common self-provided reason for not wearing the safety equipment by the participants. About two-thirds of the participants said that they should not have a choice of not following safety procedures.

The last section of the questionnaire inquired about the safety behavior of the participants' coworkers. A combined $65 \%$ of the participants said that all or most of their co-workers followed safety procedures. Similarly, about $62 \%$ of the participants said that they had not witnessed a co-worker having an accident. Nearly two-thirds of the participants said they would follow the safety procedures and not be influenced by their co-worker. About two-thirds of the participants said that they would ask their co-workers 
to follow safety procedures if they were not doing so whereas only a quarter of them said they would inform their safety supervisor. Only 155 of the participants said they would take both those decisions.

\subsubsection{Attributes vs. Perspective Relationships}

From the combined analysis, we were able to relate several responses from different sections of the questionnaire. We were able to associate participants' attributes from the first section of the questionnaire to their responses about employers' safety culture and their own safety habits. Participants with a lower level of education (School level) were more likely to feel that they had adequate knowledge about fall hazards and prevention measures compared to participants with higher education (College level and above). This contradicts the general assumption that participants with higher education would be more confident about their fall safety knowledge. One likely reason might be that students and professionals at the management level also took part in the training. As they do not work on a construction site and are less exposed to fall hazards, they might not feel that they have adequate knowledge about fall safety, and hence, their responses might have affected

our finding. We found that experienced participants were more likely to feel that they have enough knowledge of hazards and prevention measures compared to less-experienced participants. We also found that younger participants were more likely to think that they were provided with adequate safety equipment compared to older participants. Younger participants were also found to be more influenced by their co-workers than older participants. Older participants tended not to be affected by their co-workers in terms of following safety procedures. This finding shows that younger construction professionals are more vulnerable to fall hazards compared to older ones as they are not confident of 
having enough knowledge about fall hazards and tend to follow their co-workers who might not be doing the job safely.

We were also able to associate the participants' response to their employers' safety culture to their own safety habits and their coworkers' safety behaviors. We found that participants who are provided safety training by employers on site more likely feel that they have enough knowledge about hazards and prevention measures compared to participants who are not provided safety training on site. Participants who were provided safety training were also more likely to say that all or most of their co-workers follow safety procedures. Participants who were provided safety training on site by employers also tended to say that they had not witnessed a co-worker having an accident due to a fall hazard. Participants who said all the workers were provided safety training were also more likely to be not influenced by their co-workers in terms of following safety procedures compared participants who said they were not provided safety training on site by the employers. This finding shows that participants who are provided safety training by the employers are safer form fall hazards than participants who are not provided safety training by the employers.

We also found that participants who said their employers were very strict or strict about safety measures were more likely to noticed that all or most of their coworkers followed safety procedures compared to participants who said their employers were lenient or very lenient. Participants who had stricter employers also tended to say that they had not witnessed a co-worker having an accident due to fall hazards. This finding shows that 
workers whose employers are stricter about safety measures are safer from fall hazards compared to workers who have relatively lenient employers.

\section{Contributions}

This research studies the construction professionals' perspective on the safety culture of their company, their own safety habits, and their coworkers' safety behaviors. Although there have been many types of research on fall safety, there is a knowledge gap in terms of a recent study regarding the topic of this research. Previous studies (Dong et al., 2017; Chi et al., 2005; Huang et al., 2003; Hu et al., 2011) focused on the causes of fall. Other studies (Dong et al., 2013; Sa et al., 2009; Olbina et al., 2011; Dong et al., 2013) concentrated on worker characteristics and type of fall fatalities. Few studies (Roelofs et al., 2011; Menzel et al., 2010; Nissen et al., 2006) studied about workers' opinion. However, their study was not focused on falls and rather focused on comparing Hispanic and Immigrant workers' safety status with other workers. This study also uses a huge and recent data set on construction workers' perception, and finds associations between employer safety culture, workers' safety habits and behaviors as perceived by the workers themselves.

\section{Limitations}

As mentioned in the scope of this study, this study analyses data from the construction professionals who participated in the fall training only. The study does not have access to the data representing the perspectives of construction professionals who did not come to the training. However, the large number of participants from different locations all over South Florida also ensures that the data set has a general representation of South Florida construction professionals. 
Another limitation of this study is the effect on the data due to the lack of total anonymity of the participants. Although the participants were informed that their personal information was only used as a unique identifier and would not be used against them, the lack of anonymity and the fact that the training was provided under a government agency might have led some of them to choose technically correct options rather than giving their actual assessment about fall safety.

\section{Future Works/Recommendations}

Further studies should be done where workers' perspective of fall safety and their actual conduct in the workplace can be compared to get a better idea of how workers' perspective reflects on their behavior when they are at the workplace. Workplace audits can be combined with workers' self-reported perspective of the fall safety to identify the

discrepancy between what workers say and do. As mentioned earlier, anonymity plays a huge role in the response obtained from the participants of the survey. Hence, future studies of this kind where workers are convinced that their anonymity will produce more significant findings.

This study also found that perspectives of the construction professionals depend on a lot of factors; age, experience, level of education and trade are a few of those. Further research is warranted were other factors such as the size of the company, several coworkers in the team, common height during work, etc. are incorporated into similar studies. This study also identified that some groups are more at risk due to fall hazards due to the safety culture of the company, their own safety conduct, and their coworkers' safety 
behavior. Fall training should be conducted focusing on those vulnerable groups to have a more effective outcome.

\section{Conclusion}

Fall hazards lead to most deaths in the US Construction Industry. The purpose of this study was to understand the fall safety scenario in the construction industry through the construction professionals' opinions on this matter. The main contribution of this research is that it was able to analyze the construction professionals' perspective on fall safety by utilizing the survey data design with that objective. This study also addresses the research gap by analyzing a huge and most recent data set of construction workers' opinions on fall safety.

This study found some interesting trends in construction professionals' perception of fall safety. Majority of the construction professions who came to the fall training said that their employers did not always require them to produce a safety certificate to get a job. About three-fourths of the participants said that their employers were strict about safety measures. However, about $30 \%$ of the participants also said that they were not noticed by their employers if they did not follow proper safety procedures. About half of the participants said that they would be encouraged to follow safety procedures if they were rewarded by their employers. About two-thirds of the participants felt they had enough safety knowledge and agreed that workers should not have a choice of not following safety measures. About half of the participants said that they encounter fall hazards on a daily or weekly basis. About three-fifths of them said that they had not witnessed a co-worker accident due to fall hazards. 
The study also found that confidence in having enough knowledge about fall safety increased and the effect of coworkers' behavior in terms of following safety measures decreased as the age of the participants increased. We also found that the vulnerability of fall hazards decreased as the age of the participants increased. Participants who had stricter employers were safer from fall hazards compared to participants with relatively lenient employers. Participants who were not provided safety training on site were more susceptible to fall hazards compared to participants who were provided safety training by the employers.

Further study is warranted in the US construction industry regarding fall safety. The top-down and bottom-up approach needs to be combined to yield a more effective outcome in reducing fall injuries in the US construction industry. A future research example combining a survey of the workers' safety perspective with workplace audit of their safety conduct is purposed as a more comprehensive study on understanding fall safety scenario. Assuring anonymity of participants is recommended for future studies of a similar kind to have more reliable and significant data set. 
List of References

[1] US Bureau of Labor Statistics, "5,190 fatal work injuries in the United States during 2016," Bureau of Labor Statistics, U.S. Department of Labor The Economics Daily, 2016. [Online]. Available:

https://www.bls.gov/opub/ted/2017/5190-fatal-work-injuries-in-the-united-statesduring-2016.htm. [Accessed: 24-Jun-2018].

[2] OSHA, "Occupational Safety and Health Administration. Commonly Used Statistics," 2017. .

[3] Bureau of Labor Statistics, "Fatal Occupational Injuries In Florida - 2016," Atlanta, Ga., 2018.

[4] D. M. DeJoy, "Behavior change versus culture change: Divergent approaches to managing workplace safety," Saf. Sci., vol. 43, no. 2, pp. 105-129, 2005.

[5] T. S. Abdelhamid and J. G. Everett, "Identifying Root Causes of Construction Accidents," J. Constr. Eng. Manag., vol. 126, no. 1, pp. 52-60, 2000.

[6] X. S. Dong, J. A. Largay, S. D. Choi, X. Wang, C. T. Cain, and N. Romano, "Fatal falls and PFAS use in the construction industry: Findings from the NIOSH FACE reports," Accid. Anal. Prev., vol. 102, pp. 136-143, 2017.

[7] C. F. Chi, T. C. Chang, and H. I. Ting, "Accident patterns and prevention measures for fatal occupational falls in the construction industry," Appl. Ergon., vol. 36, no. 4 SPEC. ISS., pp. 391-400, 2005.

[8] X. Huang and J. Hinze, "Analysis of Construction Worker Fall Accidents," J. Constr. Eng. Manag., vol. 129, no. 3, pp. 262-271, 2003. 
[9] K. Hu, H. Rahmandad, T. Smith-Jackson, and W. Winchester, "Factors influencing the risk of falls in the constructionindustry: A review of the evidence," Constr. Manag. Econ., vol. 29, no. 4, pp. 397-416, 2011.

[10] E. A. Nadhim, C. Hon, B. Xia, I. Stewart, and D. Fang, "Falls from height in the construction industry: A critical review of the scientific literature," Int. J. Environ. Res. Public Health, vol. 13, no. 7, 2016.

[11] X. S. Dong, S. D. Choi, J. G. Borchardt, X. Wang, and J. A. Largay, "Fatal falls from roofs among U . S . construction workers," J. Safety Res., vol. 44, no. January 2007, pp. 17-24, 2013.

[12] J. Sa, D. C. Seo, and S. D. Choi, "Comparison of risk factors for falls from height between commercial and residential roofers," J. Safety Res., vol. 40, no. 1, pp. 1-6, 2009.

[13] S. Olbina, J. Hinze, and M. Ruben, "Safety in roofing: practices of contractors that employ Hispanic workers,” Prof. Saf., vol. 56-04, pp. 44-52, 2011.

[14] X. S. Dong, X. Wang, and C. Daw, "Fatal falls among older construction workers," Hum. Factors, vol. 54, no. 3, pp. 303-315, 2012.

[15] C. F. McLaren and M. L. Baldwin, "Workers ' Compensation : Benefits, Coverage, and Costs, (2015 data),” 2017.

[16] 'Chart Book (6th edition): OSHA Enforcement and Injury Costs - Workers' Compensation in Construction and Other Industries | CPWR," The Center for Construction Research and Training (CPWR). [Online]. Available: https://www.cpwr.com/chart-book-6th-edition-osha-enforcement-and-injury-costsworkers'-compensation-construction-and. [Accessed: 03-Sep-2018]. 
[17] "Safety and Health Add Value," U. S. Department of Labor. [Online]. Available: https://www.osha.gov/Publications/safety-health-addvalue.html. [Accessed: 03Sep-2018].

[18] 'Fall Protection in Residential Construction | Workers' Compensation Costs of Falls in Construction | Occupational Safety and Health Administration," OSHA, 2012. [Online]. Available:

https://www.osha.gov/doc/topics/residentialprotection/2012_fall_costs/index.html. [Accessed: 03-Sep-2018].

[19] H. J. Lipscomb, A. L. Schoenfisch, W. Cameron, K. L. Kucera, D. Adams, and B. A. Silverstein, "Twenty years of workers' compensation costs due to falls from height among union carpenters, Washington State," Am. J. Ind. Med., vol. 57, no. 9, pp. 984-991, 2014.

[20] V. Kaskutas, A. M. Dale, H. Lipscomb, and B. Evanoff, "Fall prevention and safety communication training for foremen: Report of a pilot project designed to improve residential construction safety," J. Safety Res., vol. 44, no. 1, pp. 111$118,2013$.

[21] B. Evanoff et al., "Results of a fall prevention educational intervention for residential construction," Saf. Sci., vol. 89, pp. 301-307, 2016.

[22] Q. Williams Jr, M. Ochsner, E. Marshall, L. Kimmel, and C. Martino, "The impact of a peer-led participatory health and safety training program for Latino day laborers in construction," J. Safety Res., vol. 41, no. 3, pp. 253-261, 2010.

[23] C. Roelofs, L. Sprague-Martinez, M. Brunette, and L. Azaroff, “A qualitative investigation of Hispanic construction worker perspectives on factors impacting worksite safety and risk," Environ. Heal., pp. 1-9, 2011. 
[24] N. N. Menzel and A. P. Gutierrez, "Latino Worker Perceptions of Construction Risks," Am. J. Ind. Med., vol. 187, pp. 179-187, 2010.

[25] B. Nissen, "CONSTRUCTION SAFETY PRACTICES AND IMMIGRANT WORKERS : A PILOT STUDY,” 2004.

[26] B. Nissen, A. Angee, and M. Weinstein, "The South Florida Experience," Labor Stud. J., vol. 33-1, no. March 2008, pp. 48-62, 2008.

[27] OSHA, "About OSHA Page," Occupational Safety and Health Administration, United States Department of Labor. [Online]. Available:

https://www.osha.gov/about.html. [Accessed: 09-Sep-2018].

[28] "Fatal work-related falls to a lower level increased 26 percent from 2011 to 2016," Bureau of Labor Statistics, U.S. Department of Labor, The Economics Daily. [Online]. Available: https://www.bls.gov/opub/ted/2018/fatal-work-related-fallsto-a-lower-level-increased-26-percent-from-2011-to-2016.htm. [Accessed: 03-Jul2018].

[29] US Bureau of Labor Statistics, "Static charts, Census of Fatal Occupational Injuries, 2016,” 2017.

[30] X. S. Dong, X. Wang, R. Katz, G. West, and J. Bunting, "Quarterly DATA Fall Injuries and Prevention," pp. 1-21, 2017.

[31] John H. McDonald, Handbook of Biological Statistics, Vol.2. Baltimore, MD: Sparky House Publishing, 2009.

[32] Harding University, "CHI-SQUARE: NON-PARAMETRIC COMPARISONS OF FREQUENCY,” Searcy, AR, pp. 137-146. 
APPENDIX 


\section{MEMORANDUM}

To:

CC:

From:

Date:

Proposal Title:
Dr. Nipesh Pradhananga

Saurav Pokharel

Maria Melendez-Vargas, MIBA, Coordinator

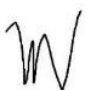

August 6, 2018

"Workers' perception of Construction Safety and Hazards in South Florida"

Approval \# IRB-18-0067-AM01

Reference \# 106520

The Florida International University Office of Research Integrity has approved the following modification(s):

- Study personnel changed: Addition of Saurav Pokharel as protocol associate.

Special Conditions: N/A

For further information, you may visit the FIU IRB website at http://research.fiu.edu/irb.

MMV/em 
Name:

\section{Background}

\begin{tabular}{|c|c|c|c|c|c|c|c|}
\hline \multicolumn{8}{|c|}{ 1. What is your role in the construction site? } \\
\hline Roofer $\square$ & \multicolumn{3}{|c|}{ Electrician $\square$} & \multicolumn{2}{|c|}{ Plumber $\square$} & Mason $\square$ & Labor $\square$ \\
\hline \multicolumn{8}{|c|}{ Please specify if not listed above: } \\
\hline \multicolumn{8}{|c|}{ 2. How many years of experience do you have in the construction industry? } \\
\hline $0 \square$ & \multicolumn{2}{|l|}{$0-2 \square$} & \multicolumn{2}{|l|}{$3-5 \square$} & \multirow[t]{2}{*}{$6-10 \square$} & $11-20 \square$ & More than $20 \square$ \\
\hline \multicolumn{7}{|c|}{ 3. How old are you? } & \\
\hline Less than $18 \square$ & \multicolumn{3}{|c|}{$18-29 \square$} & \multicolumn{2}{|l|}{$30-49 \square$} & $50-65 \square$ & More than $65 \square$ \\
\hline \multicolumn{8}{|c|}{ 4. What is your level of education? } \\
\hline \multicolumn{2}{|l|}{ School $\square$} & \multicolumn{3}{|c|}{ College degree $\square$} & \multicolumn{2}{|c|}{ Undergraduate degrec $\square$} & Graduate degrec $\square$ \\
\hline
\end{tabular}

About your employer

1. How often do you need a safety training certificate to get a job?

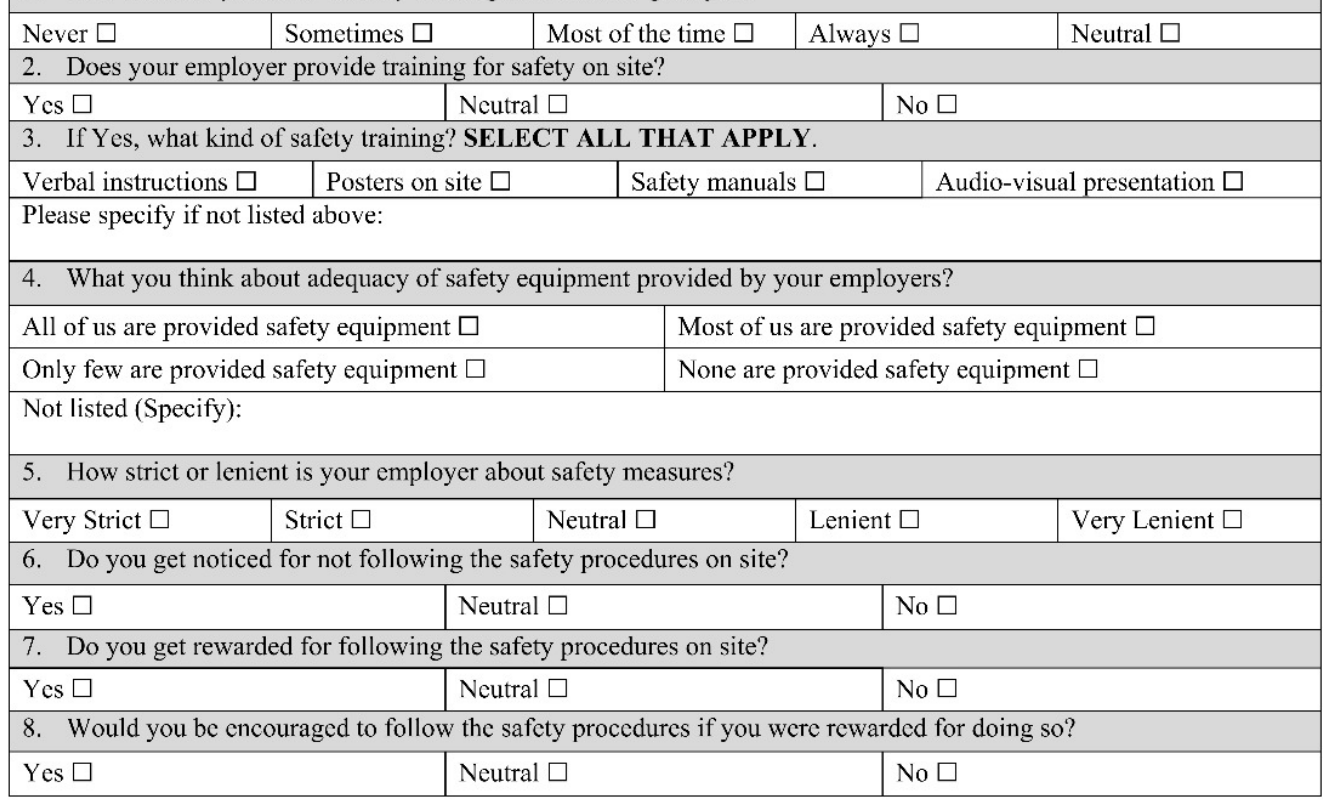

\section{About yourself}

1. Do you feel you have adequate knowledge about hazards and prevention measures?

\begin{tabular}{|l|l|l|}
\hline Yes $\square$ & Neutral $\square$ & No $\square$ \\
\hline
\end{tabular}


2. How often do you encounter fall hazards on your job?

\begin{tabular}{|l|l|l|l|l|}
\hline Every day $\square$ & Every week $\square$ & Every month $\square$ & Every 6 months $\square$ & Every year $\square$ \\
\hline
\end{tabular}

Not listed (Specify):

3. Your work requires you to stand on an unprotected surface or edge in an upper level, you consider it safe if the lower level is

\begin{tabular}{|l|l} 
Below your knec level $\square$ & Below your waist level $\square$
\end{tabular}

\begin{tabular}{|l|l}
\hline Below your eye level $\square$ & Below your head level $\square$
\end{tabular}

Not listed (Specify):

4. How often do you wear the following safety equipment while working on a construction site?

\begin{tabular}{l|c|c|c|c|c|} 
& Always & Most of the time & Sometimes & Never & Neutral \\
\hline Hard hat & $\square$ & $\square$ & $\square$ & $\square$ & $\square$ \\
\hline Safety Vest & $\square$ & $\square$ & $\square$ & $\square$ & $\square$ \\
\hline Safety Goggles & $\square$ & $\square$ & $\square$ & $\square$ & $\square$ \\
\hline Safety Boots & $\square$ & $\square$ & $\square$ & $\square$ & $\square$ \\
\hline Safety Gloves & $\square$ & $\square$ & $\square$ & $\square$ & $\square$ \\
\hline Ear Plugs & $\square$ & $\square$ & $\square$ & $\square$ & $\square$ \\
\hline Body Harness & $\square$ & $\square$ & $\square$ & $\square$ & $\square$
\end{tabular}

5. Why do you NOT wear safety equipment? SELECT ALL THAT APPLY.

\begin{tabular}{l|l|l|l}
\hline Ill-fitting $\square$ & Heavy $\square$ & Heat \& Sweat inducing $\square$ & Unattractive looking $\square$
\end{tabular}

\begin{tabular}{l|l|l}
\hline Unavailable near task site $\square$ & Restricts movement $\square$ & Reduces ability to work $\square$
\end{tabular}

Not listed (Specify):

6. Do you think you should have a choice of NOT following safety procedures?

\begin{tabular}{l|l|l} 
Yes $\square$ & Neutral $\square$ & No $\square$
\end{tabular}

About your co-workers

1. Which of the following best explains your co-workers' safety habit?

All of them follow safety procedures $\square$

Some of them follow safety procedures $\square$

Not listed (Specify):

2. Have you witnessed a co-worker having an accident due to fall hazards?

\begin{tabular}{l|l|l} 
Yes $\square$ & Neutral $\square$ & No $\square$
\end{tabular}

3. How is your behavior affected by your co-workers' safety behavior?

If my co-workers do not follow safety procedures, I don't too. $\square$

I will follow what my co-workers do, unless I feel it is unsafe. $\square$

1 will always follow the safety procedures irrespective of my co-workers. $\square$

4. What would you do if you see your co-workers not following the safety procedures in a hazardous situation? SELECT ALL THAT APPLY.

\begin{tabular}{|l|l|l}
\hline Leave them alone $\square$ & Ask them to follow safety procedures $\square$ & Inform Safety Supervisor $\square$ \\
\hline
\end{tabular}

Not Listed (Specify): 
Nombre:

Información sobre usted

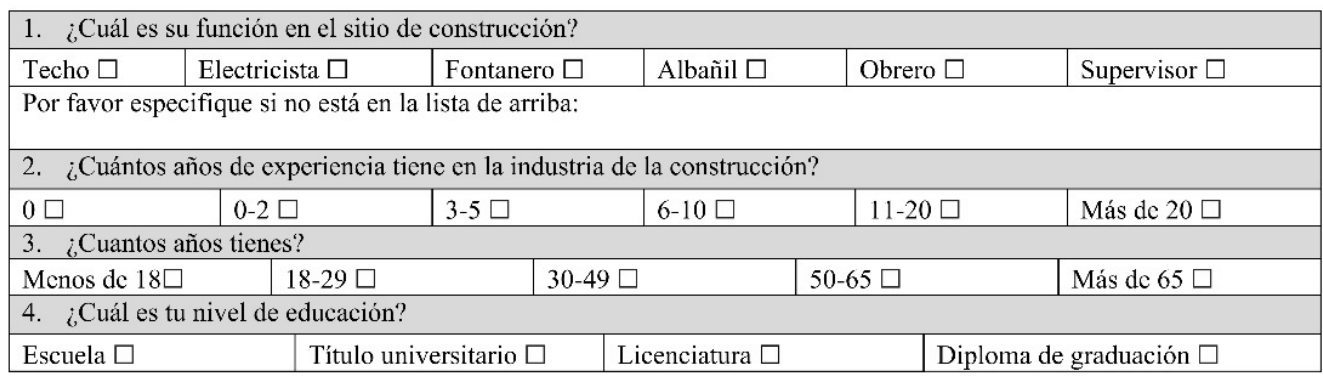

\section{Sobre su compañía}

1. ¿Con qué frecuencia necesita un certificado de capacitación de seguridad para conseguir un trabajo?

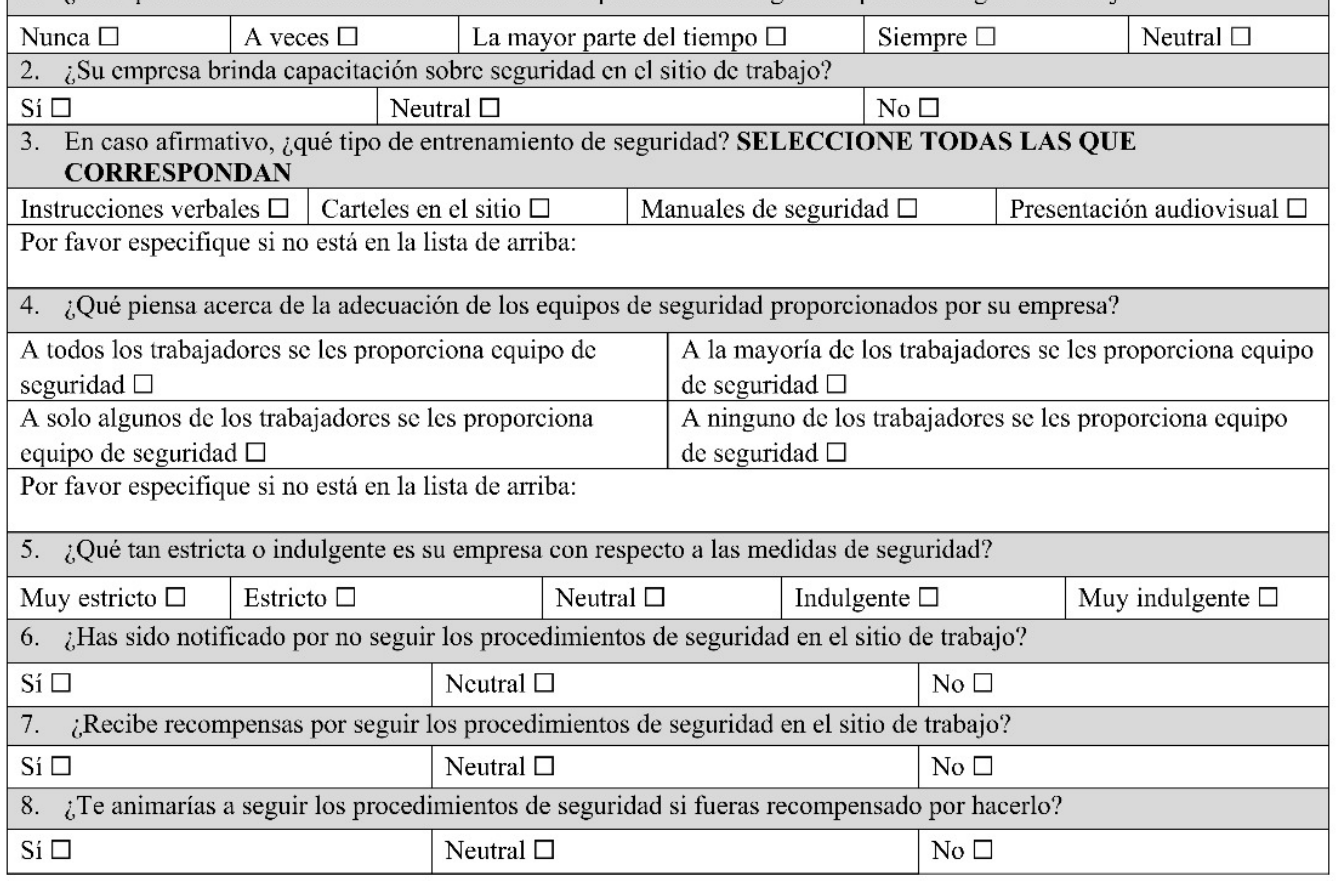

\section{Acerca de ti mismo}

1. ¿Sientes que tienes un conocimiento adecuado sobre los peligros y las medidas de prevención?

\begin{tabular}{|l|l|l}
\hline Sí $\square$ & Neutral $\square$ & No $\square$ \\
\hline
\end{tabular}


2. ¿Con qué frecuencia encuentras riesgos de caídas en tu trabajo?

\begin{tabular}{|l|l|l|l|l}
\hline Cada día $\square$ & Cada semana $\square$ & Cada mes $\square$ & Cada 6 meses $\square$ & Todos los años $\square$
\end{tabular}

Por favor especifique si no está en la lista de arriba:

3. ¿Su trabajo requiere que usted se pare sobre una superficie o borde desprotegido en un nivel superior, lo considera seguro si el nivel inferior es?

\begin{tabular}{l|l} 
Debajo de tu rodilla $\square$ & Debajo de tu cintura $\square$
\end{tabular}

\begin{tabular}{|l|l}
\hline Debajo de tu nivel de ojo $\square$ & Debajo de tu cabeza $\square$
\end{tabular}

Por favor especifique si no está en la lista de arriba:

4. ¿Con qué frecuencia usa el siguiente equipo de seguridad mientras trabaja en un sitio de construcción?

\begin{tabular}{|l|c|c|c|c|c|}
\hline & Siempre & $\begin{array}{c}\text { La mayor parte } \\
\text { dcl ticmpo }\end{array}$ & A veces & Nunca & Neutral \\
\hline Casco de seguridad & $\square$ & $\square$ & $\square$ & $\square$ & $\square$ \\
\hline Chaleco de seguridad & $\square$ & $\square$ & $\square$ & $\square$ & $\square$ \\
\hline Lentes de seguridad & $\square$ & $\square$ & $\square$ & $\square$ & $\square$ \\
\hline Botas de seguridad & $\square$ & $\square$ & $\square$ & $\square$ & $\square$ \\
\hline Guantes de seguridad & $\square$ & $\square$ & $\square$ & $\square$ & $\square$ \\
\hline Tapones para los óddos & $\square$ & $\square$ & $\square$ & $\square$ & $\square$ \\
\hline Arnés para el cuerpo & $\square$ & $\square$ & $\square$ & $\square$ & $\square$ \\
\hline
\end{tabular}

5. ¿Por qué NO usas equipo de seguridad? SELECCIONE TODAS LAS QUE CORRESPONDAN

\begin{tabular}{|l|l|l|l|}
\hline Mal ajuste $\square$ & Pesado $\square$ & Inducción de calor y sudor $\square$ & Aspecto poco atractivo $\square$ \\
\hline
\end{tabular}

\begin{tabular}{|l|l|l|}
\hline No disponible cerca del sitio de la tarea $\square$ & Restringe el movimiento $\square$ & Reduce la capacidad de trabajar $\square$
\end{tabular}

Por favor especifique si no está en la lista de arriba:

6. ¿Crees que deberías tener la opción de NO seguir los procedimientos de seguridad?

\begin{tabular}{l|l|l} 
Sí $\square$ & Neutral $\square$ & No $\square$
\end{tabular}

Sobre tus compañeros de trabajo

1. ¿Cuál de las siguientes opciones explica mejor el hábito de seguridad de tus compañeros de trabajo?

\begin{tabular}{l|l} 
Todos ellos siguen los procedimientos de seguridad $\square$ & La mayoría de ellos sigue procedimientos de seguridad
\end{tabular}

\begin{tabular}{|l|l|}
\hline Sólo unos pocos siguen procedimientos de seguridad $\square$ & Ninguno de ellos sigue procedimientos de seguridad $\square$ \\
\hline
\end{tabular}

Por favor especifique si no está en la lista de arriba:

2. ¿Has visto a un compañero de trabajo teniendo un accidente debido a riesgos de caídas?

\begin{tabular}{l|l|l} 
Sí $\square$ & Neutral $\square$ & No $\square$
\end{tabular}

3. ¿Cómo se ve afectado tu comportamiento por el comportamiento de seguridad de tus compañeros de trabajo?

Si mis compañeros de trabajo no siguen los procedimientos de seguridad, yo tampoco. $\square$

Sigo lo que hacen mis compañeros de trabajo, a menos que sienta que no es seguro. $\square$

Siempre seguiré los procedimientos de seguridad independientemente de lo que hagan mis compañeros de trabajo. $\square$

4. ¿Qué harías si ves a tus compañeros de trabajo sin seguir los procedimientos de seguridad en una situación pcligrosa? SELECCIONE TODAS LAS QUE CORRESPONDAN.

\begin{tabular}{l|l}
\hline Déjalos en paz $\square$ & Pídeles que sigan los procedimientos de
\end{tabular} seguridad $\square$

Informa al supervisor de seguridad $\square$

Por favor especifique si no está en la lista de arriba: 